\title{
Ethical Responsibility to Distant Others through the Coffee Industry
}

\section{William John Durbin}

A 120 point thesis submitted to Victoria University of Wellington in partial fulfilment of the requirements for the degree of Master of Development Studies

School of Geography, Environment and Earth Sciences

Victoria University of Wellington 



\section{Table of Contents}

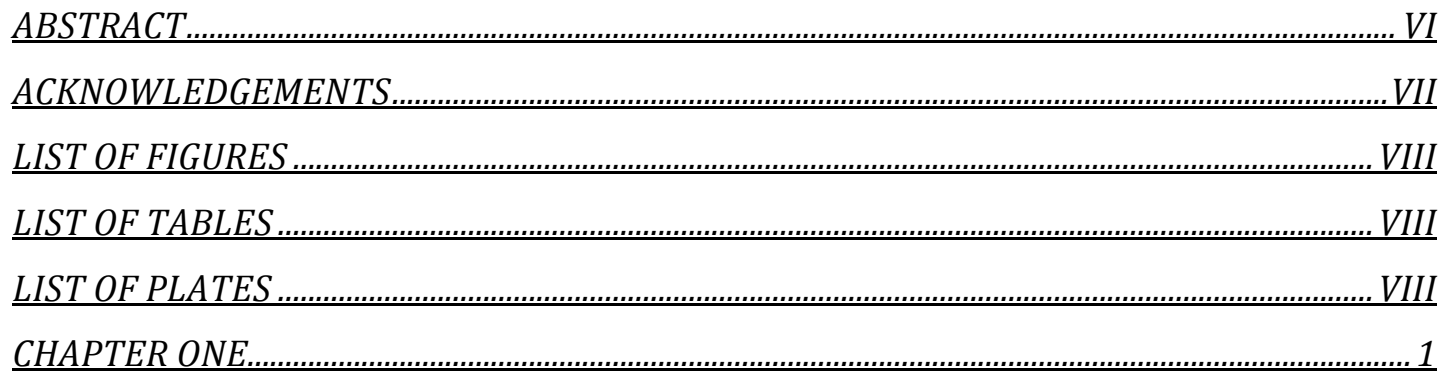

INTRODUCTION: CAN A COFFEE HERE, MAKE A DIFFERENCE 'OVER THERE'?...................... 1

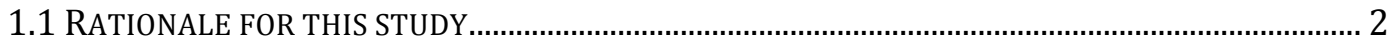

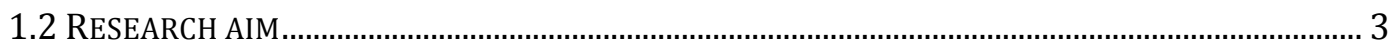

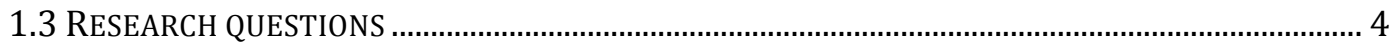

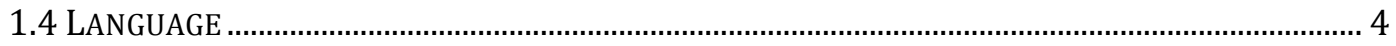

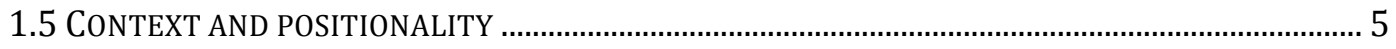

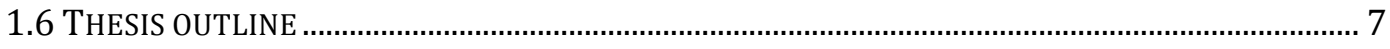

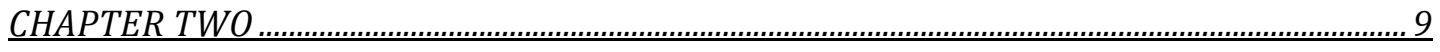

POST-DEVELOPMENT THEORY AND ETHICAL CONSUMPTION ……………………........... 9

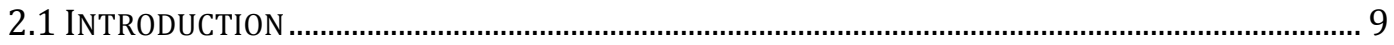

2.2 SIGNIFICANCE OF POST-DEVELOPMENT FOR MY RESEARCH........................................................ 9

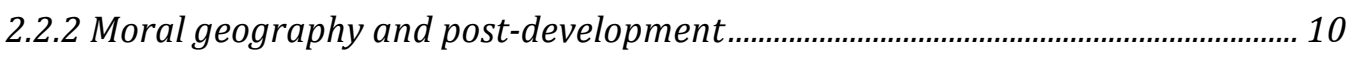

2.3 EARLY POST-DEVELOPMENT ……...................................................................................

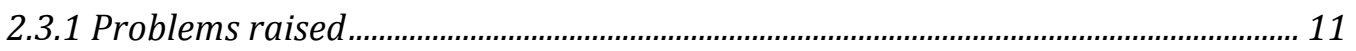

2.3.2 Responses to mainstream development t..................................................................... 13

2.4 POST-DEVELOPMENT CRITIQUES ..........................................................................................13

2.4.1 What to retain from post-development ................................................................... 15

2.5 ETHICS AND CONSUMPTION IN DEVELOPMENT …………..................................................17

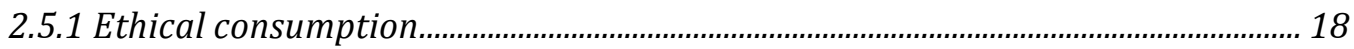

2.5.2 Critiques of ethical consumption ……………………………………………........ 19

2.6 POST-DEVELOPMENT PRACTICE AND FAIR TRADE ……………………..................................20

2.7 RETHINKING THE DEVELOPMENT DISCOURSE, IN LIGHT OF POST-DEVELOPMENT .....................21

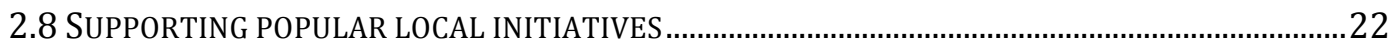

2.9 CONSUMING ETHICALLY IN NEW ZEALAND AS SOLIDARITY WITH DISTANT OTHERS.................23

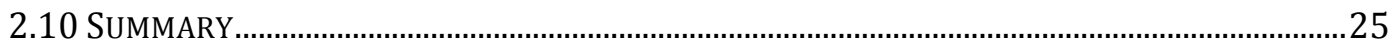

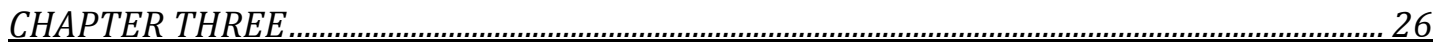

METHODOLOGY: INVESTIGATING ETHICAL PRODUCTION AND CONSUMPTION ............... 26

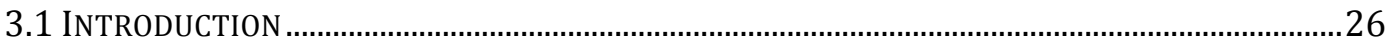

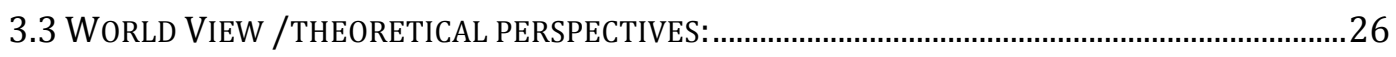

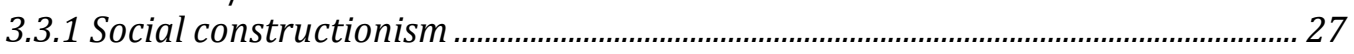

3.3.2 Critical theory ..................................................................................................................... 27

3.4 RESEARCH METHODS......................................................................................................28

3.4.1 Appreciative Inquiry...................................................................................................... 28

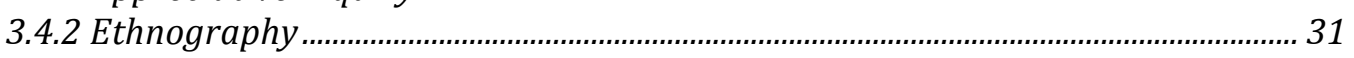

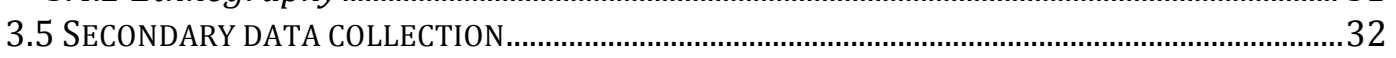

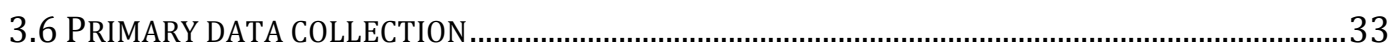

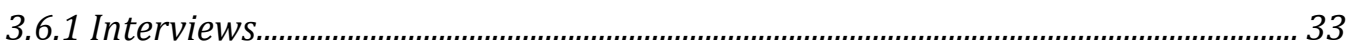

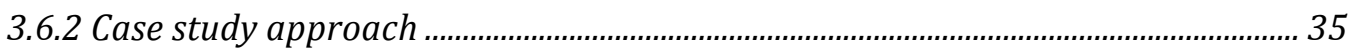

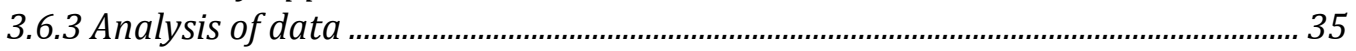

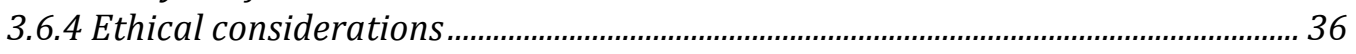

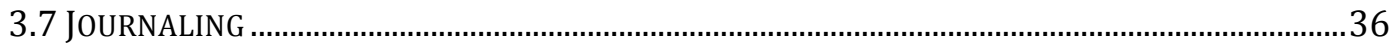


3.8 RESEARCH LIMITATIONS AND OPPORTUNITIES FOR FURTHER RESEARCH …….......................... 37

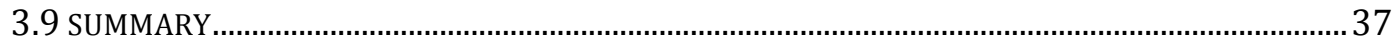

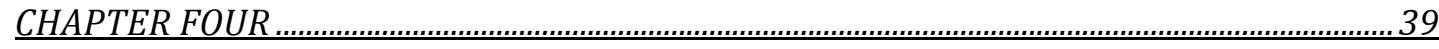

TRANSITIONS IN CAPITALISM AND THE MARKET: A NEW SPACE FOR ETHICAL

BUSINESS?.............................................................................................................

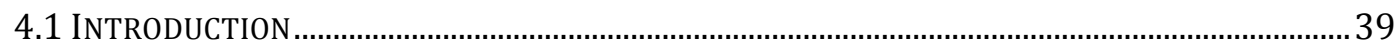

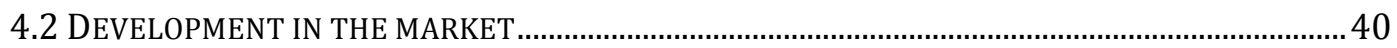

4.3 TRADITIONAL VIEWS OF DEVELOPMENT IN THE MARKET ........................................................40

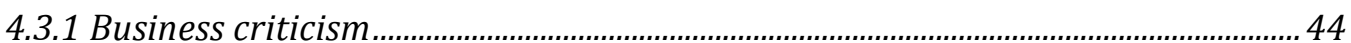

4.4 NEW FORMS OF DEVELOPMENT IN THE MARKET ………….................................................... 46

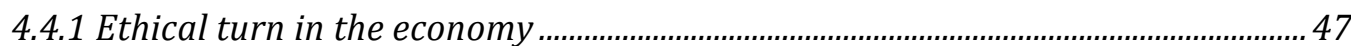

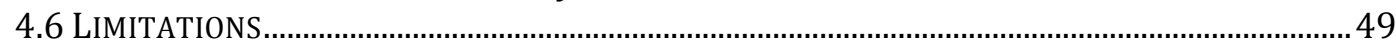

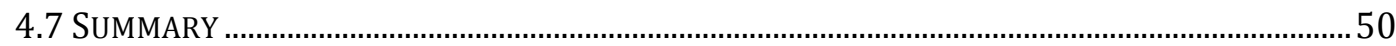

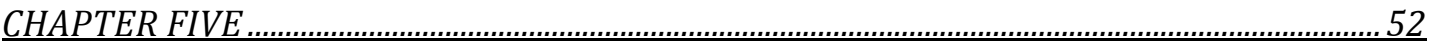

BUSINESS AS A SOCIAL ENTERPRISE IN THE FAIR TRADE COFFEE INDUSTRY _.................52

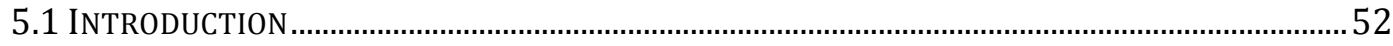

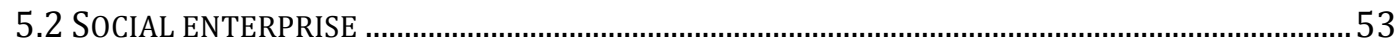

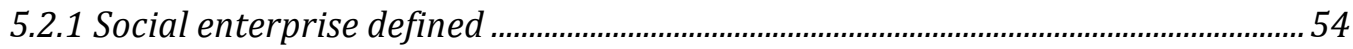

5.2.2 A new space for social enterprise in society …….....................................................5

5.2.3 Social enterprise continuum ……......................................................................... 55

5.2.4 Limitations and cautions with social enterprise ......................................................5

5.3 THE COFFEE INDUSTRY AS A PLACE FOR SOCIAL ENTERPRISE ..................................................58

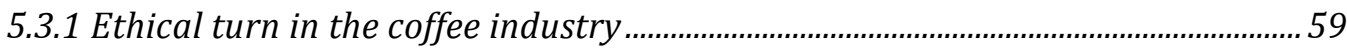

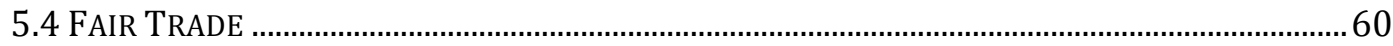

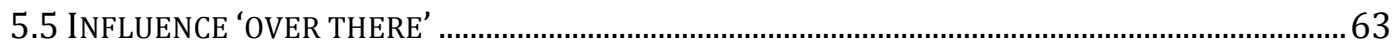

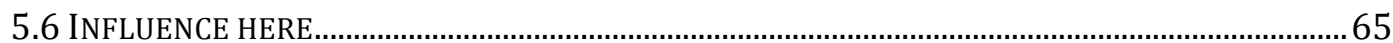

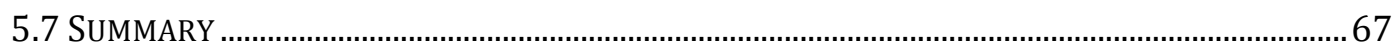

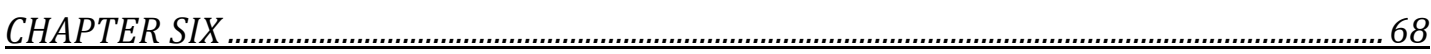

CASE STUDIES

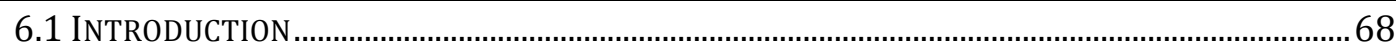

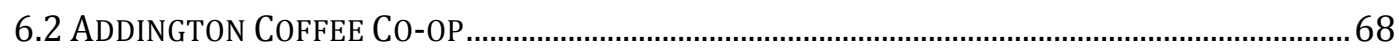

6.2 .1 History

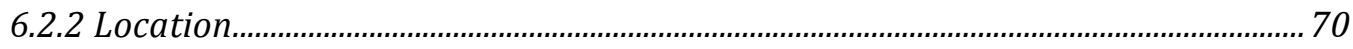

6.2.3 Supply model for their coffee ……........................................................................ 70

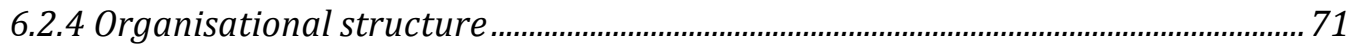

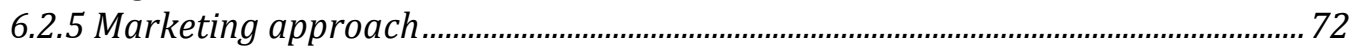

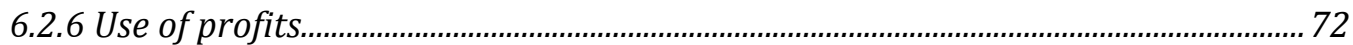

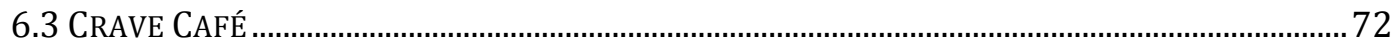

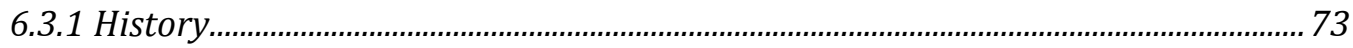

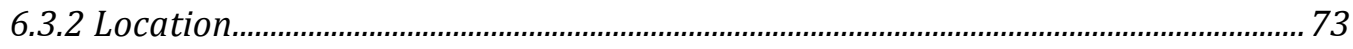

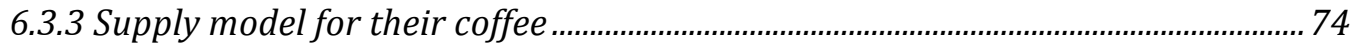

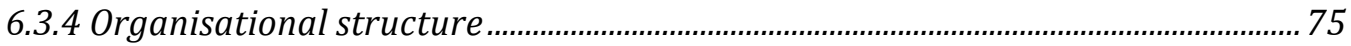

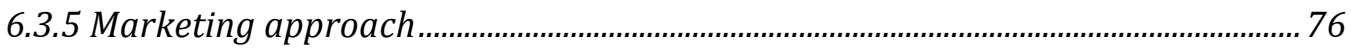

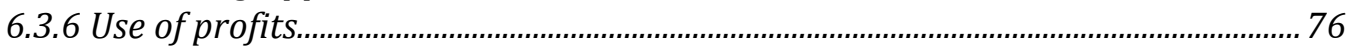

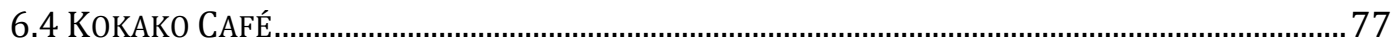

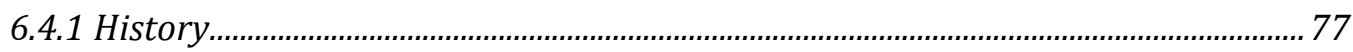

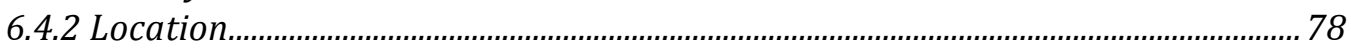

6.4.3 Supply model for their coffee ..................................................................................... 78

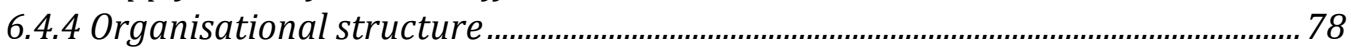

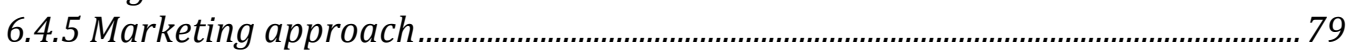

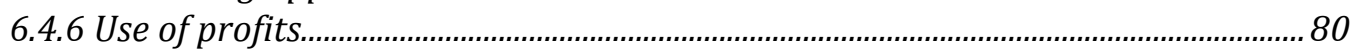




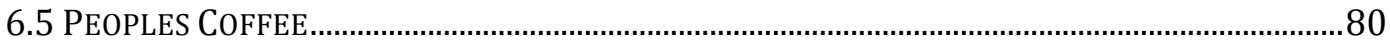

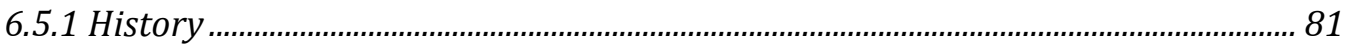

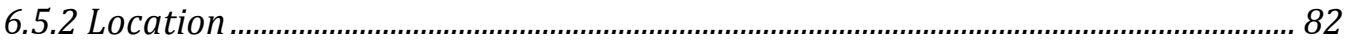

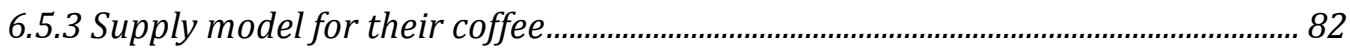

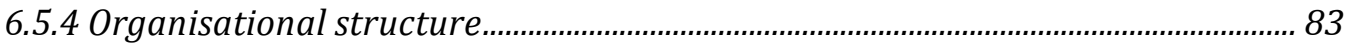

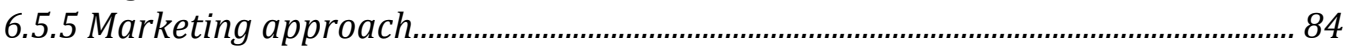

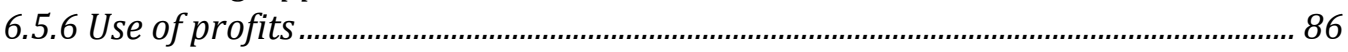

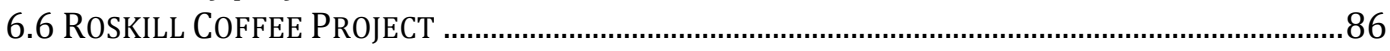

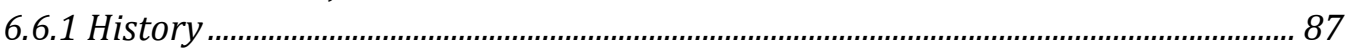

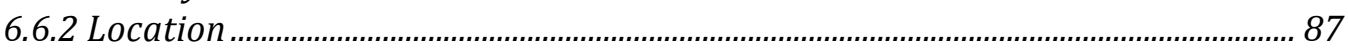

6.6.3 Supply model for their coffee .................................................................................... 88

6.6.4 Organisational structure ......................................................................................... 88

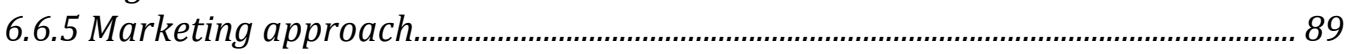

6.6.6 Use of profits ........................................................................................................... 90

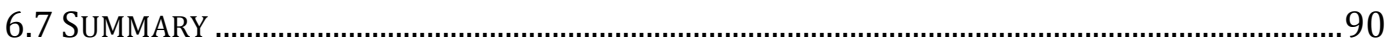

CHAPTER SEVEN ……................................................................................................................... 91

ETHICAL RESPONSIBILITY OF CONSUMERS AND BUSINESS OWNERS _................................... 91

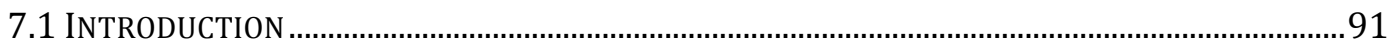

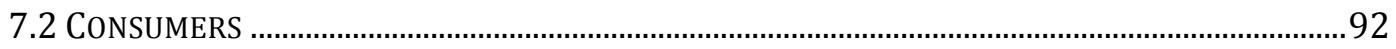

7.2.1 Importance of the consumer...................................................................................... 92

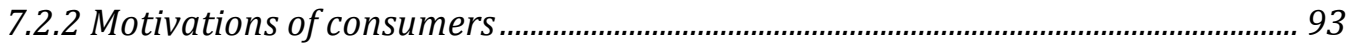

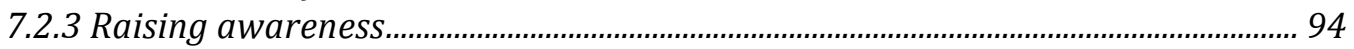

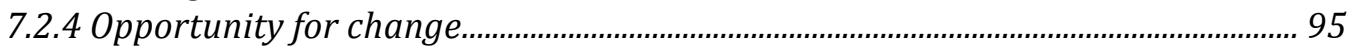

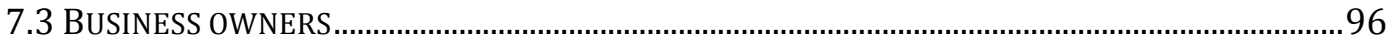

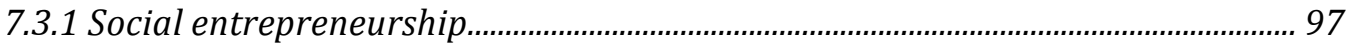

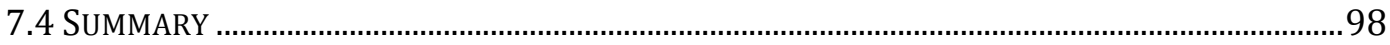

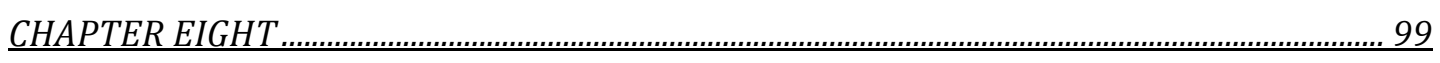

CASE STUDY DISCUSSION

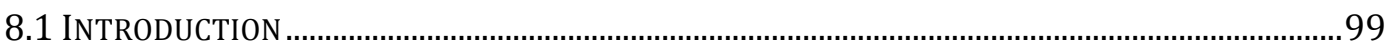

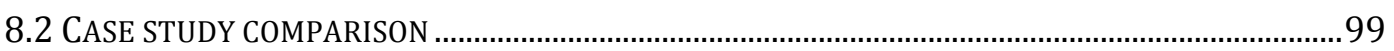

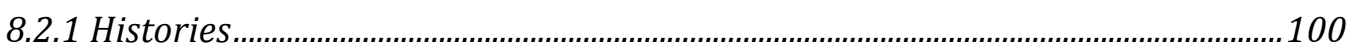

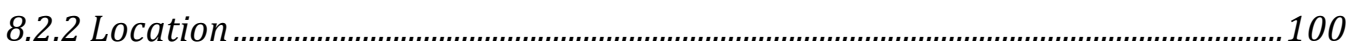

8.2.3 Supply model for their coffee ...................................................................................101

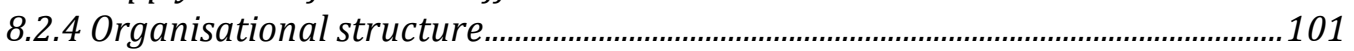

8.2.5 Marketing Approach …...........................................................................................102

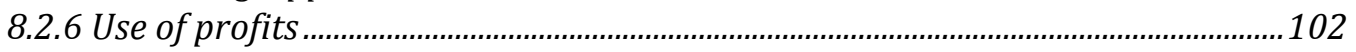

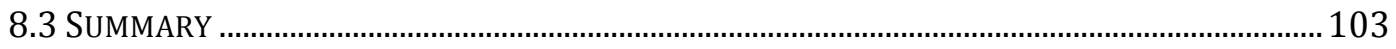

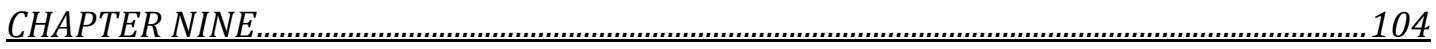

CONCLUSION

9.1 INTRODUCTION ........................................................................................................ 104

9.2 WHAT MOTIVATES THE SOCIAL ENTREPRENEURS BEHIND THE RISE OF FAIR TRADE COFFEE RETAILING IN NEW ZEALAND, AND TO WHAT EXTENT ARE THEY DRIVEN BY RESPONSIBILITY TO

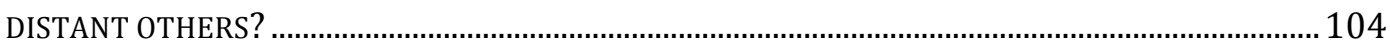

9.3 TO WHAT EXTENT DOES THE RISE OF THE FAIR TRADE COFFEE RETAIL SECTOR IN NEW ZEALAND REPRESENT AN EXAMPLE OF POST-DEVELOPMENT THEORY IN ACTION? ...................... 106

9.4 USING A CASE STUDY APPROACH, HOW DO THE MOTIVES FOR ESTABLISHING SOCIAL ENTERPRISE IN THE COFFEE RETAIL SECTOR IN NZ VARY BETWEEN DIFFERENT COMPANIES?...107 9.5 TO WHAT EXTENT ARE THE RETAILERS I INVESTIGATE TO BE CHARACTERISED AS SOCIAL

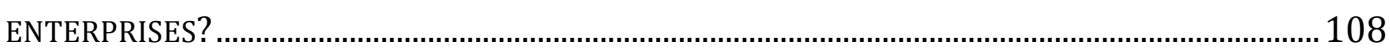
9.6 WHAT ARE THE REMAINING CHALLENGES FOR THE APPLICATION OF A JUST COFFEE RETAIL

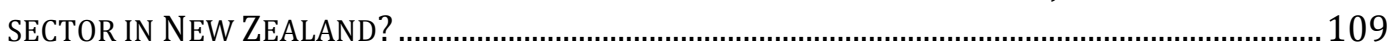




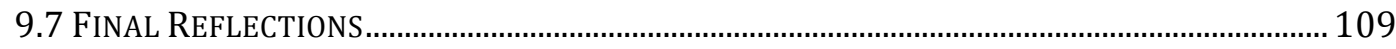

APPENDIX 1: PARTICIPANT INFORMATION SHEET AND CONSENT FORM ……................. 111

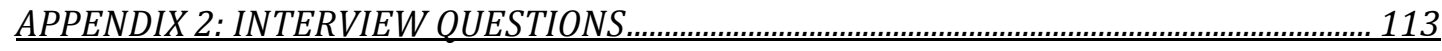

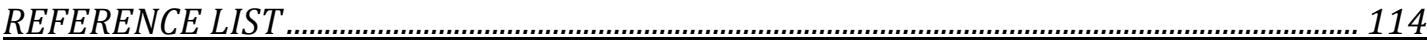




\begin{abstract}
How we live our lives here in New Zealand affects others who are distant from us. We live in a world with many networks across space, which connect people with radically different lifestyles. These connections create an avenue to respond to the poverty of these 'distant others'. One such network of connections is the coffee industry. Ethical consumption and social entrepreneurship within the coffee industry are a means to address development issues, and ultimately poverty. This research will look into coffee social enterprises, and how they can be included in a post-development theoretical framework. In particular, it will discuss the motivations of social entrepreneurs involved in the coffee companies interviewed.

Post-development provides a theoretical framework for this research of coffee social enterprises. It provides a critique to mainstream development, and has questioned how development is done, as well as its very validity. In doing so, it has encouraged new ways of 'doing development'. One example of this is Sally Matthews' three responses the wealthy can have to poverty: first, rethinking of the development discourse in light of post-development; secondly, supporting popular initiatives; and thirdly, solidarity with distant others here at home.

This is an appreciative inquiry into different coffee companies, using qualitative ethnographic methods. Seven in-depth interviews have been conducted with managers, past owners or head roasters, as well as one with an expert on social enterprise.
\end{abstract}




\section{Acknowledgements}

First of all, I acknowledge Jesus Christ as my inspiration and impetus, in this research and in life.

To my family and friends, thank you for your support, and ideas that have contributed to my work.

To Kareen, thank you for encouraging and believing in me, for pushing me, and for providing me with invaluable ideas and research material.

To Arla, Heather and Kathy, thanks for laughs, good chats and for inspiring me to push this thesis further than I would have myself.

Thanks Warwick for your supervision over the last year. Your encouragement, critique and time have been appreciated.

And finally thank you to all the participants for taking time out of your busy schedules to be a part of this research. Without your ideas and your work this research would not be possible. 


\section{List of Figures}

Figure 1: PhASES OF APPRECIATIVE INQUIRY - THE 4-D MODEL (LUdEM, COOPERRIDER, \& BARRETT, 2001).

FIGURE 2: SOCIAL ENTERPRISE CONTINUUM

\section{List of Tables}

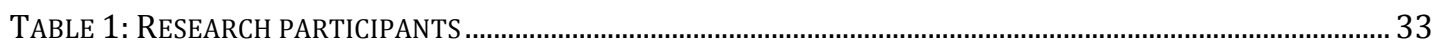

TABLE 2: HiSTORICAL DEBATES ON COMMODITY MARKETS AND DEVELOPMENT (DAVIRON \& PONTE, 2005) .. 42

\section{List of Plates}

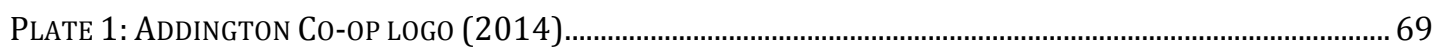

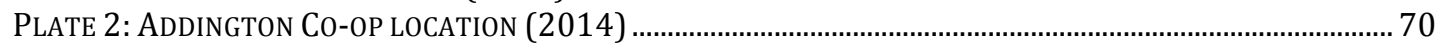

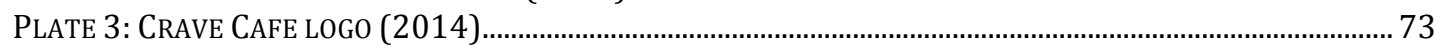

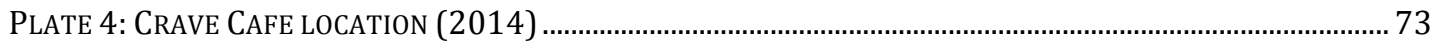

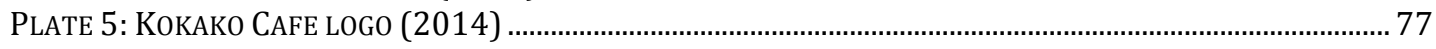

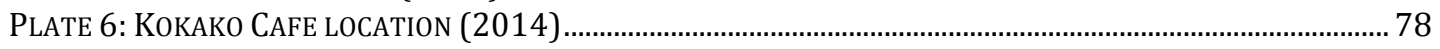

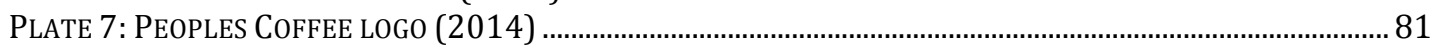

Plate 8: Peoples Coffee, Constable StReEt location (2014) .................................................................... 82

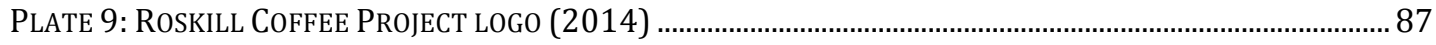

PLATE 10: RoSKILL CofFEe PRoJeCt LOCATION (2014) ....................................................................................... 87 


\section{Chapter One}

\section{Introduction: Can a Coffee Here, Make a Difference 'Over \\ There'?}

Living in New Zealand can feel far from many forms of development issues in the world. It can also seem that there are limited ways to provide solutions to development issues from a distance. This thesis aims to show that coffee social enterprises, and an alternative approach to development, can in part be solutions to this challenge. It will look at coffee companies which have a social enterprise model for their business and will discuss how these can be an avenue for individuals in New Zealand to outwork their ethical responsibility to distant others. This will be discussed through the lens of post-development theory, to see whether these companies, the social entrepreneurs who run them, and the individuals who patronise them can be included in the development discourse. A key part of this work then is to link post-development theory, and its practical outworking, to coffee social enterprises.

As will be shown throughout this thesis, wealth and poverty are linked, so to address issues of poverty the field of development must begin to look at the lifestyles of the wealthy and how they affect development issues. This is especially pertinent when looking at consumption culture in the West, and the effect this has on distant others in their own context. Researching in a developed context does not just include looking at how western lifestyles negatively influence development issues. My research aims to look at how ethical consumption here in New Zealand can produce positive outcomes for distant others. More specifically, it will look at this in the context of coffee social enterprises, and how 'doing development' may be possible in these companies. This is a specific context, and these ideas may or may not be transferable to other parts of Western society, or other commodities. Nevertheless, there is potential to outwork ethical responsibility through this avenue. 


\subsection{Rationale for this study}

If we are to change the relations between the more and less privileged, we need to change the privileged too: we need to change the way in which the more privileged regard their own privilege and the poverty of others. Thus addressing poverty and oppression involves not only intervening in the lives of those who are impoverished and oppressed, but also in our own lives, in our ways of seeing and living in the world, in what happens 'here at home' (Matthews (2008) P.1045)

This challenge Matthews makes for the wealthy to reflect on their lifestyles and the effect they have on others in the world caught my attention and was what inspired this research. It alluded to a type of development work that would require a response from people here in New Zealand as individuals. As a result of the webs of social relations, brought on by economic and ecological interdependence, poverty and wealth have something to do with each other, so we who are relatively privileged have a moral duty to respond in some way to the plight of the poor (Matthews, 2008; Matthews, 2007). Matthews (2007) defines the relatively privileged as the global consumer class and as a social minority, and the poor as those who struggle to meet their everyday material needs. Matthews (2008) promotes three responses to poverty that the wealthy should take. They are, first, rethinking the development discourse in light of post-development, second, supporting popular initiatives, and thirdly, solidarity with distant others here at home. These stood out to me as easily applicable to real life. One avenue to do this that became apparent was people in New Zealand patronising coffee social enterprises that have committed to fair and ethical trade. These companies have a focus on caring for the farmers (and the co-operatives they are often a part of) who produce the coffee their companies are based on, and the local communities they work within here in New Zealand. It seemed that outworking post-development practice could be done in this context.

Global interconnections and networks, specifically the coffee industry, are a significant part of the world we live in. Matthews (2008) states, "international trade, economic integration and new information and 
communication technologies mean that the local and the global are tied up in complex ways" (P.1040). This has created "a world of expanding social relations" (Smith, 2000, p. 93). But, this globalised world does not guarantee that benefits from these connections will be widely distributed. These beliefs have costs on people and ecosystems that have little voice, and inequalities are growing (Gibson-Graham, Cameron, \& Healy, 2013). These interconnections are not necessarily causal, one-to-one links, but more like 'feedbacks', or indirect links (George, 1997).

Applying post-development practice to the coffee industry is particularly significant for development because of who works in the coffee industry, and its scale. Coffee is the second most traded commodity in the world, second only to oil, and is produced by around 30 million smallholder farmers (Chandler, 2013). It is produced in more than 60 countries, and for many of these countries it can account for $75 \%$ of their total export earnings (Jolliffe, 2010). These farmers are found in Latin America, Africa and Asia (Fridell, 2007). They often represent some of the world's poorest and most vulnerable communities, so there is potential to affect significant change through the coffee industry (Chandler, 2013). Fridell (2007) states:

"At the root of the coffee industry is a grossly unequal social class hierarchy in which all participants are driven, directly or indirectly, by the capitalist imperatives of competition, accumulation, profit maximization, and increasing labour productivity. At the bottom of the hierarchy are the rural workers and small-scale farmers in the South" (p.124)

So it plays an integral part in developed and developing countries, and society as a whole. It is a direct link between these two 'worlds' and provides an opportunity for influence.

\subsection{Research aim}

The aim of this research is to apply post-development theory to the practice of coffee companies that do social enterprise work here in New Zealand, and with the coffee farmers they get coffee from. This can be an avenue for individuals to achieve positive development outcomes through their lifestyle choices. It will 
also look at the role of social entrepreneurs in the fair trade coffee industry in New Zealand.

\subsection{Research questions}

To achieve this aim, the following central question has been posed:

- What motivates the social entrepreneurs behind the rise of fair trade coffee retailing in New Zealand, and to what extent are they driven by responsibility to distant others?

Subsequent questions that arise from this are:

- To what extent does the rise of the fair trade coffee retail sector in New Zealand represent an example of post-development theory in action?

- Using a case study approach, how do the motives for establishing social enterprise in the coffee retail sector in NZ vary between different companies?

- To what extent are the retailers I investigate to be characterised as social enterprises?

- What are the remaining challenges for the application of a just coffee retail sector in New Zealand?

\subsection{Language}

I will be using the term 'distant others' in my thesis, which is taken from Matthews (2008), as well as Corbridge (1998). This defines people "whose experiences and ... problems are radically different from our own, such that there is a great difference between us even when we meet face to face" (Matthews, 2008). There is difficulty with this term though, as is shown by Marcus (2007) when discussing Edward Said's idea of Orientalism, in that it is a polarizing term. This states that defining the 'East' is done in comparison to the 'West', which ties the two in a relationship of power and hierarchy (Marcus, 2007). Marcus (2007) argues that the East is often defined as elusive, languid and traditional; whereas the West is seen as energetic, inventive, progressing, and Christian. These definitions are similar to distant others in that they are based on difference more than similarity. Although it is undeniable that a 
person in New Zealand lives a radically different life to a coffee farmer in Africa or Latin America, caution should be taken about the power dynamic and alienation that this could create. I must be careful then not to essentialise coffee farmers, and the communities they are a part of. Coffee farmers as distant others are not heard in this discussion; they are only spoken on behalf of by the coffee companies. Representation of local coffee farmers then becomes critical, both from me and from the coffee companies. This ability to represent others and create knowledge about them can be a position of power, and can be used to dominate others (Marcus, 2007). It may also unintentionally reinforce stereotypes about distant others (Marcus, 2007).

Another term that is used when discussing the responsibility of individuals in New Zealand's to distant others is how that is 'outworked'. This is used to describe the process of an individual's ethical responsibility being demonstrated or expressed through coffee companies.

\section{$\underline{1.5 \text { Context and positionality }}$}

Positionality is important because it frames social and professional relationships as well as research (Chacko, 2004, p. 33). England (1994) states that we "are differently positioned subjects with different biographies, we are not dematerialized, disembodied entities" that can claim objectivity (pp.84, 85). To be aware of this contextuality is to "occupy a position that is between the objective pole of scientific theorizing and the subjective pole of empathy and understanding" (Chacko, 2004, p.34). All knowledge is situated, so neutrality is neither possible nor desirable (Manzo \& Brightbill, 2007). Also, acknowledging positionality in formulating, conducting and reporting on fieldwork can make researchers more aware of power relations and how they affect the exchange of production of information and knowledge (Chacko, 2004).

I am 28, Christian, Caucasian, male, and heterosexual. I live in Wellington, the capital of New Zealand, a country that was colonised by my British ancestors. I have a Bachelor of Arts in Development Studies and International Relations, and am currently studying for a Masters in Development Studies. I am the youngest of five children, and come from a well-off family where only my 
father works. My Christian worldview is important to acknowledge here, as it is what has influenced me to conduct this research as I have. It is what attracted me to Development Studies originally, as caring for the poor and the call to 'love thy neighbour' are core tenets of biblical theology. Also, post-development's reflexive view on the lifestyle of the wealthy, and the need to change, fits with this, as well as Christian views of self-sacrifice. Christianity has also had its influence on Fair Trade, which connects my Christian worldview to discussions about ethics being outworked in the coffee industry (JustShare, 2012).

As with all research, the context of my research is of critical importance. My research focuses on New Zealand, coffee social enterprises situated here and the lifestyle of those that patronize these cafés. This is because I see a gap in the literature and discussions about the impact of lifestyles of people in New Zealand on development. Post-development is looking at this topic (as will be outlined in the theory chapter), which is where I gained my inspiration. Also in discussions on coffee, there is much literature on Fair trade, coffee cooperatives and so on. I hope then to provide a fresh perspective on this topic and speak to a gap in the literature. As my research context is also my home context, it is heavily linked with my positionality.

As a researcher I am embedded in the field context I am researching. This means that I am unable to gain an outsider's perspective on the issue of a wealthy person's lifestyle, and how it affects distant others. It does mean though that this issue is intensely personal to me, as I myself can be considered 'part of the problem'. I am one of the wealthy trying to understand the impact my life here in New Zealand has on others. Particularly, I am trying to understand, as a consumer, the impact of my life decisions on primary producers, such as coffee farmers. I have had some experience of being in a developing country (I have been to Nepal twice), but I do not know what it is like to be a coffee farmer in countries such as Nicaragua or Ethiopia. I can never fully understand what it is to be in their position. This means I am creating knowledge about people I have not met nor have I been to the country they are from. The research then runs the risk of contributing to North-centric thinking. This is where the role of the coffee companies becomes so crucially important in reality and in my research, as they represent these coffee farmers to New Zealanders and can raise 
awareness about them and their lives. In this way, coffee brings together two very different contexts, and has the potential to be done in an intimate and close way.

For the majority of my research I have been working out of an office in a university. This has created a disconnect with some of the people I am considering in this discussion (namely the coffee farmers). In many ways though this was deliberate, as it represents the real-world nature of the commodity chain. There were 'field trips', but they were to other cities (Auckland and Christchurch) that are similar to my own. It could be argued that I am in my 'field', and that I have never left. Doing fieldwork at home has been an interesting process. Compared to other Masters students, who have encountered protests, coups, and wars, my masters has been a relatively easy process. This shows me the sheltered lifestyle of the wealthy in the West, and how distant the problems of poverty and conflict can feel. Also, all my interviews were in English so there were no issues with translation.

\subsection{Thesis outline}

The outline for this thesis is as follows. Chapter two will look into postdevelopment. It will look at this first as it provides the theoretical perspective through which this research will be seen. It will discuss the significance of postdevelopment for my research, the various iterations it has gone through, its connections to moral geography, the critiques of post-development, and its practical application. Particularly I will discuss Sally Matthews' (2008) 3 responses to poverty: first, rethinking the development discourse in light of post-development; second, supporting popular initiatives; and thirdly, solidarity with distant others here at home. Chapter three will discuss my methodology. Critical theory and social constructionism help to uncover non-explicit relations, to create progressive social change and to rouse moral questions in this discussion, so that knowledge and social action go hand-in-hand. It will then discuss the research methods of ethnography and Appreciative Inquiry (AI), of which semi-structured interviews were the main tools that was used. AI takes an appreciative stance to research, looking for the good in the research context. 
Chapter four will look at the global economy as the context for this research. It will discuss two alternatives for development in the economy. The first is the traditional economic development approach, which this thesis takes a critical view of. The other style of development encourages a reframing of the economy, which includes more social and environmental considerations. This is part of an ethical turn that has occurred in the economy. From this chapter on I will be integrating primary data in my discussion. The participant's views have informed these contexts chapters so their views are included accordingly.

Chapter five will look at the coffee industry and fair trade in more detail, as well as discussing social enterprise as a model. Social enterprise can be seen as a part of the ethical turn in the economy. There are multiple manifestations of social enterprise, which will be described. Chapter six will discuss each coffee company as a case study. Their history, location, coffee procurement, organisational make-up (particularly in relation to the social enterprise continuum shown in the previous chapter), marketing approach, and use of profits will be discussed. Chapter seven will look at business owners and consumers that go to the coffee companies. It will look at consumers, their complicity in economic issues, but also the opportunities they have to make change through social enterprises. It will discuss consumer motivations, and how companies try to appeal to these motivations. Business owners, and their role as gatekeepers will also be discussed, as will the way literature on social entrepreneurship frames their work. Finally, Chapter eight will provide a discussion of the case studies, comparing and contrasting their features. 


\section{Chapter Two}

\section{Post-Development Theory and Ethical Consumption}

\subsection{Introduction}

This chapter will discuss the theoretical foundation and framework for my research. Predominantly this will be the recent (the last 10 years or so) discussion from post-development theory. It will also include ideas that have arisen from moral geography. Many of the ideas from these two fields are linked and overlap significantly. This chapter will begin by discussing the choice of post-development as the foundation for my research. It will then outline early post-development theory, with its critiques and responses to mainstream development. There has been criticism of this early work, which will be discussed next. But, acknowledging these criticisms as valid, there is still value to take from post-development. This is particularly true in its discussions of reemphasising ethics in development, and its practical suggestions for outworking post-development. From an ethical perspective, this chapter will look into ethical consumption, which is the critical action for individuals in enacting postdevelopment. Finally, it will discuss Matthews (2008) 3 responses to poverty: first, rethinking the development discourse in light of post-development; second, supporting popular initiatives; and thirdly, solidarity with distant others here at home.

\subsection{Significance of post-development for my research}

Post-development makes a valuable contribution to the development discourse. Ziai (2007) sees post-development "as a new school of thought within NorthSouth relations, which has a lot of critical and constructive potential, but needs to be further refined, explored and argued over" (p.9). The post-development critique should be seen as a starting point from which to examine the transformation of development interventions in local encounters as a promising line of future research (Ziai, 2007). So this thesis will utilise both post- 
development's critique of mainstream development, and its progression to guide this research. Post-development is useful for two reasons. Firstly, it has emphasised the inclusion of ethics back in to the development discourse. This is important to provide a theoretical foundation within development on the discussion of ethical responsibility to distant others. Matthews (2008) describes distant others as those whose lives, experiences and problems are radically different from our own, "such that there is great distance between us even when we meet face to face" (p.1036). Rawlsian theory asks us to put ourselves in place of others, but phrases it quite abstractly, whereas Corbridge (1998) argues that we should put ourselves in the shoes of other positions that are real and occupied (concrete-embodied Other), as opposed to a generalised or disembodied Other. Secondly, the practical outworking of post-development discussions provides useful opportunities for alternative development practice. This is where coffee social enterprises can be conceived as a model for outworking development 'here at home'. Sachs (2010) states “delinking the desire for equity from economic growth and relinking it to community- and culture-based notions of well-being will be the cornerstone of the postdevelopment age" (p.xii). This is essentially what social enterprise coffee companies are attempting to do, both here in New Zealand communities, and abroad. Post-development also re-politicises development, and the individual within it, thus providing scope and opportunities to effect positive change against structural issues.

\subsubsection{Moral geography and post-development}

Moral geography adds to the discussion of post-development by providing a theoretical landscape through which to discuss post-development. Smith (2000) states, "we live in a world of expanding social relations", in which the benefits are not widely distributed and the capacity to harm distant others exists (p.93). This is one of the basic problems addressed through applying post-development practice to the coffee industry. It also complements well the discussions of bringing ethics back into development, through ideas of 'caring at a distance' and 'geographies of responsibility'. I will predominantly be looking at 
transnational geographies of care and responsibility. ${ }^{1}$ Many of the theorists in this field refer to post-development theorists such as Corbridge so there is an interdisciplinary link.

Difference is important in moral geography, as it shows "diversity, or pluralism, in moral beliefs and practices, as they vary from place to place (and from time to time), as integral features of human cultures and ways of life" (Smith, 2000, p. 14). This could become an issue when applying ethics grounded in western thought to non-western contexts. Moral geography also incorporates the idea of social justice, which is "considered to focus on distribution, on how the benefits and burdens involved in social life are distributed among persons or groups, on the process involved, and on criteria which may be applied to its moral evaluation" (Smith, 2000, p.136). It has universality as a concept, but also has particularity in practice (Smith, 2000). Therefore it could work well for creating a basis for acting ethically across distance through the coffee industry.

\subsection{Early post-development}

To orient the discussion on post-development, I will begin by outlining the progression of post-development thought over the last 20 years or so. This is in no way comprehensive, but will give a useful backdrop to this chapter. Development is a contested term, and its original intentions are heavily debated. At its core, development is about inequality between rich and poor in the world, and how this injustice can be resolved. Post-development argues that, overall, development has failed to address this core concern. This put into question the very desirability of development.

\subsubsection{Problems raised}

Post-development arose from the so-called impasse in development, as a rejection of the very desirability of development (Storey, 2000). There was a movement of scholars and activists in the 1980s who became so dissatisfied

\footnotetext{
${ }^{1}$ For geographies of care and responsibility within the state, please see Bosco (2007) 'Hungry Children and Networks of Aid in Argentina: Thinking About Geographies of Responsibility and Care'
} 
with the concept and practice of development, that they dismissed development altogether (Ziai, 2007). Theorists such as Latouche saw development as the westernization of the world and condemned capitalist development in the periphery, as well the very idea of development itself (Pieterse, 2000; Corbridge, 1998). Yapa described development as the geopolitics of the US, a disease that invented poverty in the so-called Third World (Corbridge, 1998). Ziai (2007) believes that the traditional concept of development is Eurocentric, and has authoritarian and technocratic implications. Michel Foucault was a massive influence, encouraging theorists to view development as a discourse. Kiely (as cited in Storey, 2000) summarised that "development constitutes a specific way of thinking about the world, a particular form of knowledge. Development is, in the Foucauldian sense, a particular discourse that does not reflect but actually constructs reality. In doing so, it closes off alternative ways of thinking and so constitutes a form of power" (p.40). Thomas (2000) states:

"The very idea of development is under challenge to an extent not foreseen even a few years ago. Voices from the 'post-development' school claim that, at best, development has failed, or at worst it was always a 'hoax', designed to cover up violent damage being done to the so-called 'developing' world and its people" (as cited in Ziai, 2007, p. 3).

It criticised mainstream development as being external, based on the industrialized world, and that it is unable to guarantee the wellbeing of indigenous people (Giovannini, 2013; Pieterse, 2000). Again this shows the failure of development to achieve its core intention.

Some seminal pieces of work were, first, the Development Dictionary, which argued against the industrial model of development, its role in the Cold War period, that the gap between rich and poor countries was widening, and that development was eliminating cultural diversity through westernisation (Ziai, 2007). Second, Escobar's Encountering Development argued that development discourse created a power apparatus over the Third World, and argued for alternatives to, not just within, development (Ziai, 2007). The third piece of work was The Post-Development Reader by Rahnema and Bawtree, which argued that development did not meet the needs and aspirations of the 
poor, but was an ideology born in the North to serve their economic and geopolitical needs (Ziai, 2007). It carried the disheartening message to local people in developing countries "that their traditional modes of living, thinking and doing have doomed them to a subhuman condition..." (Rahnema and Bawtree, 1997, as cited in Ziai, 2007).

\subsubsection{Responses to mainstream development}

Thus, according to these theorists, a new era of post-development thinking was required to move on from the flaws found in development. This era had to be based on a new rationale from 'vernacular societies', but not a return to a 'state of nature' type society (Ziai, 2007). Rahnema (1997) elaborates that the "end of development should not be seen as an end to the search for new possibilities of change.... It should only mean that the binary, the mechanistic, the reductionist, the inhumane and the ultimately self-destructive approach to change is over" (as cited in Ziai, 2007, p.5). These possibilities are outlined in the suggested post-development practice, which will be discussed later.

Some argue (Corbridge labels these as the post-Left) that the ethical response to these unequal relations is to seperate from these unequal relationships of the world systems, while others (the New Right) argue that individuals in any given region or country are entirely the authors of their own fortunes (Corbridge, 1998). The view posed by the post-Left seems impractical, as this is unlikely to happen in the globalised world where people need or desire goods not produced where they are; and the New-Right view is misguided to believe that individuals have complete control over their circumstances.

\subsection{Post-development critiques}

There are valid criticisms of post-development that should be acknowledged. Many view it as too essentialist, too neat and partial (Corbridge, 2007). Viewing development as a singular, monolithic, form of self-interested Northern economic imperialism and universally disastrous modernism is neither accurate nor helpful, as development is far more heterogeneous in discourse, policy and practice than this view claims (Simon, 2006). Post-development can show too 
negative or repressive a view of the operation of power through development, which links it too closely together with notions of colonization (Brigg, 2002). This conception of power "leads some post-development writers to overly aggregate the operation of power, to ascribe intentionality to a singular historical force such as 'the Americans', and to take an untenable oppositional stance" (Brigg, 2002, p.433). What is needed is a more nuanced view of the use of power, which sees it as an apparatus that can influence peoples lives "without totalizing the force relations involved" (Brigg, 2002, p.433).

In many ways, post-development reinforces its monolithic nature by ignoring different streams of development theory in the past. Moore (as cited in Simon, 2006) agrees that highly localised cultural politics that have affected trans-local discourses of development have been omitted from the postdevelopment discussion. Through viewing development as westernisation it ignores the massive influence the South has had on development theory, which homogenises development, and conceals divergences within development (Pieterse, 2000). Furthermore, the post-modernist views of more pluralism, more tolerance and more openness to the right of difference are indeed universalising ideas in and of themselves (Corbridge, 1998). Post-development then has the potential to make as many assumptions about others as the worst forms of development, as its anti-essentialism conceals a romantic populism that can be as intentionalist as other forms of development (Corbridge, 1998). So in its attempt to show development's universalising nature, it does it itself. This can also romanticise local knowledges and perspectives of others in the world, assuming that they are all pure and good.

Pieterse (2000) believes post-development is the same as postmodernism in that it is ultimately directionless, and refuses, or is not interested in, translating critique into construction. King (2008) agrees, stating that postdevelopment does not allow for any development discourse that goes beyond relativism. The above perhaps is starting to change, as people are beginning to ground post-development by providing a practical outworking of its critique. This is what I aim to do in applying post-development practice to coffee social enterprises. It encourages continued interventions in poor regions, not the 
separation of developed and developing countries that some post-development theorists have promoted (Matthews, 2008).

Post-development successfully identified valid issues with development, but was in danger of throwing the baby out with the bath water. Simon (2006) states we need to "not tar all development organisations, strategies and efforts with the same congealing brush, since there is, and always has been, considerably greater diversity of ideology, discourse, policy and practice than can readily be reduced to the caricature of supposedly monolithic and uniform modernisation project constituting development in the antidevelopment canon" (p.11).

\subsubsection{What to retain from post-development}

Although these are legitimate critiques of post-development, it still has much to offer. Overall, it provides an avenue to attempt new forms of development work, removing the prescriptive nature development can have. It is aware of development's failures, but has new found positivity that makes it hopeful for new possibilities. It is part of a discursive turn in the social sciences and local and indigenous knowledges that is moving away from centering on economic relations, and providing an avenue for "criticisms and analyses that promote more ethical and nourishing engagements across cultures and lifestyles that coalesce at the site of development efforts" (Brigg, 2002, p. 422). Crucially, it argues, "it is not just the poor but also the rich, and their economy as well, that have to be called into question. At any rate, the quest for fairness in a finite world means in the first place changing the rich, not the poor. Poverty alleviation, in other words, cannot be separated from wealth alleviation" (Sachs, 2010, p.xiv).

Gibson-Graham (2005) describes post-development's deconstructive project as focused on unhinging notions of development from the European experience of industrial growth and capitalist expansion; decentering conceptions of economy and de-essentialising economic logics as the motor of history; loosening the discursive grip of unilinear trajectories on narratives of change; and undermining the hierarchical valuations of cultures, practices and 
economic sites. As stated earlier, post-development provides important perspectives for my research, as it "accept that past development theory and practice may have been flawed but warn that we must be careful not to allow our disillusionment with development to prevent us from responding meaningfully and in a timely fashion to poverty" (Matthews, 2008). Pieterse (2000) agrees that one can share post-development's observations without arriving at the conclusion of the rejection of development.

The deconstruction of development in this way is critical so that through reconstruction new ideas can be incorporated, making it more applicable to varying peoples and contexts. This in turn means that projects do not always have to work in every context. It is acceptable to only be suitable for some people or contexts. This could potentially be the case for Fair Trade and the use of coffee social enterprises as a mode of development. Gibson-Graham et al. (2013) puts it well:

\footnotetext{
The challenge of postdevelopment is not to give up on development, nor to see all development practice - past, present and future, in wealthy and poor countries - as tainted, failed, retrograde; as though there were something necessarily problematic and destructive about deliberate attempts to increase social wellbeing through economic intervention; as though there were a space of purity beyond or outside development that we could access through renunciation. The challenge is to imagine and practice development differently (p.6).
}

David Simon (2006) argues that replacing the term or concept of development will not address poverty and inequality; rather the more progressive and empowering visions within development should be separated from conventional versions of modernisation-as-development.

There is a shift away from looking at how development shapes and constitutes people and place, to looking at how development actors are able to shape places and development and/or seek alternatives (McGregor, 2009). In doing so, development is becoming repoliticised (McGregor, 2009), as it has been de-politicised in the past, being placed 'off to the side' without the ability to effect change on issues that have political implications. This means that individuals can effect change, and no longer have to view structural issues as impossible to change. Post-development then refutes the status quo as 
unchangeable. From a human geography perspective, Cloke (2002) argues that "living ethically and acting politically can be essentially intertwined with a sense for the other in a sensitive, committed and active approach to the subject" (p.601). This would entail a continuing engagement in collective political action against ordered evil (Cloke, 2002). Thus, making an ethical decision to support a coffee social enterprise can be seen as caring for distant others, but also a political statement against unequal economic structures.

\subsection{Ethics and consumption in development}

Corbridge states that, through post-development, "development studies [was] confronted with a sustained assault upon its humanistic assumptions and its alleged (im) morality. From the 1980s onwards, there were issues raised about development based on moral terms because of its foundation on scientific merit" (Corbridge, 1998). Post-development promotes bringing ethical claims back into development and questions "how the privileged are to respond meaningfully to their own situation of privilege and to the contrasting situations of poverty experienced by so many" (Matthews, 2008, P.1035). This is something that post-development, and development in general, has not fully addressed (Matthews, 2008). But what is clear now is that a "reasoned defence of mainstream development studies must move beyond the technical (positive) to engage with a growing literature on the ethics of development and transnational justice" (Corbridge, 1998, p.36, 37). And as stated earlier, this aspect of post-development allows ideas from moral geography to be incorporated into development.

An important part of bringing ethical claims into development is coming to terms with the privilege of people in such countries as New Zealand. As part of this the idea must be refuted that we are all born free and earn our wealth and rewards by the talents we possess (Corbridge, 1998). But this so-called talent effect is mostly an effect of the accident of birth or geography (Corbridge, 1998). No one could disagree that a talented girl in a poor family in Bangladesh is not going to command the same sorts of rewards as a lazy so-and-so in the UK, the USA, or New Zealand for that matter. Roemer (as cited in Corbridge, 
1998) argues that this inequity is not random because of the power the already possessing classes have to exclude the dispossessed from the means of production and the means of empowerment and advancement. Furthermore, the existing distributions of wealth, property and power cannot be justified by appeals to prior acts of entrepreneurship or 'talent' (Corbridge, 1998).

\subsubsection{Ethical consumption}

Ethical concerns become particularly important in development when discussing market exchanges, as they often involve people in radically different situations. Karl Marx promoted the idea of commodity fetishism, which argues that people express their social relations over distance through commodities produced (Luetchford, 2008). Corbridge (1998) argues that we live in a "modern age in which the lives of distant strangers are ever more entangled in a dense web of disembedded and unequal relations" (p.44). As I have argued elsewhere, a commitment to responding to poverty is necessary for people living in developed countries. One such response could be ethical consumption. Corbridge (1998) argues that Western consumers should be concerned about the fate of "producers because these producers suffer in relationships of market exchange which are unfair or exploitative ( $\mathrm{p} .44$, italics in original text). Furthermore, Sachs (2010) states, if "there is to be some kind of prosperity for all world citizens, the Euro-Atlantic model of production and consumption needs to be superseded, making room for modes of well-being that leave only a light footprint on the earth" (p. xii).

Recently, the idea of ethical consumption (which is linked to economic decision-making) has begun to be more popular (Gibson-Graham, 2005). In geography, consumption is central in considerations of morality, ethics and responsibility (Barnett, Cloke, Clarke, \& Malpass, 2005). Addressing social problems is not a new idea, but what is new is addressing it as a consumer (Barnett, Cloke, Clarke, \& Malpass, 2005). And the ethical turn in development has allowed this to be incorporated into development. There are two ways ethics and consumption are linked. First, because consumption is a crucial part of global commodity chains, it can serve as an entry-point for thinking about 
political and ethical responsibility; secondly, consumption is an avenue for autonomous action, reflecting on ones conduct, and self-fashioning of relationships between selves and others (Miller, 1995, 1998 as cited in Barnett, Cloke, Clarke, \& Malpass, 2005). Ethical consumption requires consumers to have knowledge about the consequences of spatially extended processes, and the ability to change one's lifestyle (Barnett, Clarke, \& Malpass, 2005). This is not entirely up to the consumer however, as their responsibility to distant others is influenced by their autonomy in the structure of society (Barnett, Clarke, \& Malpass, 2005). But it is a way to induce meaningful change from a distance in the patterns of conduct of powerful economic and bureaucratic systems (Barnett, Cloke, Clarke, \& Malpass, 2005).

I believe that coffee social enterprises provide an avenue for outworking ethical consumption. In choosing to patronize these cafés people are making a conscious and political decision not to support cafés that use unethically traded coffee, and therefore not buying in to unjust economic systems.

\subsubsection{Critiques of ethical consumption}

There are some problems with ethical consumption, though. Because there is an unequal power dynamic in economic relationships, the issue of acting ethically will always be contentious (McEwan \& Goodman, 2010). And, ethical consumption relies on discourses of the 'self' and the 'other', the 'haves' (Northern consumers) and the 'have nots' (Southern producers), which reinforces these power dynamics (McEwan \& Goodman, 2010). Also, outworking political activism through consumption is limited to those who have the resources, knowledge and status to do so (McEwan \& Goodman, 2010). We need to question whether global inequalities and moral injusticies can even be rectified through the market or whether this simply works toward a kinder, simpler, counter hegemonic globalisation (McEwan \& Goodman, 2010). Ethical consumption should not been seen as the key ethical arena because it can neglect other important modes of ethical action, such as protests (McEwan \& Goodman, 2010). These are important concerns to be conscious of, but they 
should be seen as exactly that; they are not reason enough to dismiss ethical consumption as something that will not work.

\subsection{Post-development practice and fair trade}

Post-development has begun to promote practical alternative forms to traditional mainstream development that embody its criticisms. Simon (2006) sees this as the moving on from early post-development and anti-development to "the envisioning of alternatives or successors (in the literal meaning of the term) to conventional development" (p.11). McGregor (2009) agrees that postdevelopment, "from its early beginnings as an angry collection of critiques that saw only oppression and injustice within development industries... is broadening to incorporate a research programme that seeks out opportunities and possibilities in a range of contemporary social and economic processes" (p.1699). Post-development is moving towards a much more inclusive approach which attempts to define appropriate post-development practices according to post-development theory (McGregor, 2009). Sachs (2010) states:

"Initiatives attempt to push back the predominance of the economic world-view. They oppose the secular trend to functionalize work, education and the land in order to boost economic efficiency, insisting on the right to act according to values of culture, democracy and justice" (p.xiii).

In the South, initiatives emphasize community rights to natural resources, selfgovernance and indigenous ways of knowing and acting; in the North, postdevelopment action centres on eco-fair businesses in manufacture, trade and banking, the rediscovery of the commons in nature and society, open-source collaboration, self-sufficiency in consumption and profit-making, and renewed attention to non-material values (Sachs, 2010). This then gives space to include coffee social enterprises as an alternative form of development, as they work in both the North and the South and embody these values.

One suggestion Simon (2006) makes is to research how progressive trading structures, such as Fair Trade, ensure adequate working standards. These "campaigns are making a real difference to the producers and workers 
concerned, reducing or avoiding exploitation, and enabling Fair Trade beneficiaries to improve their quality of life and undertake social investment in their communities" (Simon, 2006, p.17). They are struggling though, "not least because of the price premium that many Northern consumers are unwilling or unable to pay, even if they are aware of the campaigns" (Simon, 2006, p.17). This requires a change in decision-making and lifestyle for consumers, placing the onus on them to make ethically traded coffee more viable. People can build the economies we live in, and take economic matters into their own hands to create a socially and environmentally just world (Gibson-Graham, Cameron, \& Healy, 2013). This is an empowering thought, and shows how individuals have the ability to address structural problems.

Simon then encourages Fair Trade to become mainstream, which has happened, but now has created issues of Fair Trade being co-opted and removed from its original intention to serve and empower the poor. Also, Ferguson (as cited in Matthews, 2008) argues that academics can advance the causes of Third World peoples through their work (public speaking, advocacy and research) at home. In the process of my research, then, and the discussions I have with others I am raising awareness and informing people about the poor, and what they can do here at home to help them.

The main example of post-development practice that I will look at is Matthews (2008) three responses to poverty: rethinking the development discourse, in light of post-development, supporting popular initiatives, and solidarity with distant others here at home. I will discuss these in further detail next.

\subsection{Rethinking the development discourse, in light of post-development}

The idea of rethinking the development discourse is largely what this chapter has been about. Rist argues that 'evident ideas' that are part of the development discourse should be questioned, and alternatives should be proposed and debated (Matthews, 2008). Some post-development theorists recommend that because development has failed to alleviate poverty, the only solution is abandoning development altogether. Aside from the impracticality of 
this (due to the interconnected world we live in), to disengage, in my view, would be wrong. Corbridge (as cited in Matthews, 2008) argues that political localism betrays reason and claims of justice, and becomes "at best activistic and at worst deconstructive to the point of voyeurism" (p.1039). I agree with the standpoint of Matthews (2008), who argues for the importance of continuing to respond to the plights of distant others, but not continuing along the same old road of development. So it is not a question of whether to intervene or not, rather a question of how. The basis of intervention, not whether to intervene or not, is what should be questioned (Matthews, 2008).

There is a shift away from only looking at how development shapes and constitutes people and place, to looking at how development actors have agency to shape places and development and/or seek alternatives to it (McGregor, 2009). This is a more empowering view of development, and links to the ideas of doing development at home which I will discuss further. People in New Zealand, then, can be seen as development actors, and therefore can address development issues. So coffee social enterprises such as Peoples Coffee, and Addington Co-op could be viewed as an alternative development model that sits outside traditional development, thus broadening what it is to 'do development'.

\subsection{Supporting popular local initiatives}

There is growing research that emphasises the importance of understanding place-based studies and local-scale action over generic global scale initiatives, which is where many post-development alternatives are coming from (McGregor, 2009; Ziai, 2007). McGregor (2009) argues the "protection and promotion of local cultural priorities and beliefs is seen as critical in much post-development writing as it is here that alternative imaginaries and counter-hegemonic beliefs reside" (p.1697). In doing this local knowledge is privileged, which as shown earlier is a critical part of postdevelopment. This can exert different political identities in the development from those conceived in the West (Cupples, Glynn, \& Larios, 2007). It also involves the projections of a specific place (such as the source of coffee beans) into (global) space, which can destabilise the "certitudes, rigidities, and fixities" 
that mainstream development tries to engender, which in turn can empower people from that place (Cupples, Glynn, \& Larios, 2007, p.798). I believe supporting local coffee co-operatives (via purchasing coffee at a coffee social enterprises) in developing countries can be viewed as supporting a popular initiative. What would be interesting is to look at how these grassroots movements can be connected to grassroots movements in the developed world, in which coffee social enterprises could be included. To find a balance of knowledge from North and South would be critical in this.

One consideration to make in this discussion is where the states in the South fit in, and if they are being empowered, or bypassed by this process (Silk, 2004). Silk (2004) discusses how the state and NGOs could support social movements, but does not discuss how private enterprise could do this while caring at a distance. There could potentially be a reluctance to discuss this, as private enterprises in developing countries historically have not taken much care in their work to support indigenous peoples (not to mention environmental care). Supporting popular initiatives could be problematic for companies, as it could put the production of the resources they utilise in jeopardy. But if a company has a solid commitment to ethical work and caring for those in the producing country, and is held accountable by its consumers, there is potential for it to support and promote popular initiatives.

\subsection{Consuming ethically in New Zealand as solidarity with distant others}

Development is traditionally perceived as something that is done 'over there' in the field, away from the lives and realities of western people. But what I contend is because we live in such a connected world, how we live our lives in developed countries influences greatly the lives of distant others. As a result of the webs of social relations, brought on by economic and ecological interdependence, poverty and wealth have something to do with each other, so we who are relatively privileged have a moral duty to respond in some way to the plight of the poor (Matthews, 2008; Matthews, 2007). Post-development has raised the question of "how privileged people are to respond meaningfully to their own situation of privilege and to the contrasting situations of poverty experienced by 
so many" (Matthews, 2008). Referring to Yapa, Matthews (2008) argues "poverty arises within a complex nexus of relations and that this nexus extends into non-poor communities and regions. It follows, then, that one can help to transform the relations that cause poverty and oppression without necessarily intervening in the poor community itself" (p.1038). Theorists such as Ferguson, Yapa and Rist through their critique of traditional development, agree that responding to the poor doesn't necessarily mean going 'out there' (Matthews, 2008). While they focus on researchers providing advice to the state and donors, I argue that development work can be done in a developed country context by varying actors.

Unequal market relationships between North and South are apparent in the coffee industry, and therefore is a potential place to stand in solidarity with coffee farmers and their communities. Coffee social enterprises give us the opportunity to know those people, even though most of us will never meet them. Harvey (as cited in Corbridge, 1998) argues that the "multiple mediated relations which constitute our society across space and time are just as important and "authentic" as unmediated face-to-face relations" (p.44). Therefore, the lives people that are hidden through the market exchange are just as important to care for as those near us. This also means development work can be done here in New Zealand through addressing the lifestyles, particularly consumption, of its citizens. The challenge then is to link "local identities, practices and agendas" here in New Zealand "to broader and multiscale campaigns and 'projects' for progressive and radical change that are substantively postcolonial and critically (post) developmental" (Simon, 2006, p.17). This, I believe, can include supporting co-operatives through social enterprises in the coffee industry.

As stated earlier, distant others are those whose lives are radically different to ours. Silk (2004) argues, "to care for distant strangers is to extend the geographical, psychological and political scope of a universal human activity" (p.229). Geographers see distance as a barrier, and that caring up close is easier; as David Smith states, "distance leads to indifference" because it "hides consequences" (Barnett, Cloke, Clarke, \& Malpass, 2005, p. 24). While "responding to the plight of distant others is complex and fraught with potential 
pitfalls, it is neither possible nor desirable to advocate just 'leaving the poor alone'. It is not possible because our lives are intricately tied up with the poor as there are so many economic, social and political webs of relations from which we cannot realistically completely extricate ourselves" (Matthews, 2008, p.1040). Silk (2004) argues that our increasing ability to act at a distance, influencing people far away, places upon us a special obligation to care for those among them who are particular vulnerable (Silk, 2004). Indeed Barnet et al. argue, "there is no good reason to suppose that spatial distance necessarily diminishes either a felt responsibility or practical capacity to care for others" (Barnett, Cloke, Clarke, \& Malpass, 2005, p. 25).

\subsection{Summary}

This chapter has shown how post-development theory informs my research on coffee social enterprises, and ethical responsibility. Post-development's critique of development, particularly its ethical critique, has given scope for discussion of the responsibility the privileged have to distant others. I have incorporated moral geography here to define the geographical networks that this discussion includes, as well as terms such as distance, difference, place, and how consumption is an avenue for outworking ethics. Post-development also provides practical alternatives to mainstream development, which incorporates its critique. Matthews' three responses to poverty for the privileged provide the theoretical base for my research. This chapter has encapsulated the first response she promotes of rethinking the development discourse, in light of post-development. The following chapters will include the next two (supporting popular initiatives and solidarity with distant others here at home) through discussions on findings from the interviews conducted. 


\section{Chapter Three}

\section{Methodology: Investigating Ethical Production and Consumption}

\subsection{Introduction}

Transparency in research methodology is a critical part of modern research. Becoming aware of the researcher, and how they have researched helps provide insight into the material that is produced. This chapter will discuss my approach to this research. Overall, it has been an intuitive process of trial and error throughout. First, it will discuss my theoretical perspective, which utilises critical theory and social constructionism. Critical theory helps uncover nonexplicit relations, to create progressive social change and to include moral questions in this discussion; it also helps to place these relations in history. Social constructionism states that knowledge and social action go hand-in-hand, which means that awareness should change actions and lifestyle. The main theoretical perspective I adopt though is post-development, which has been discussed at length in the previous chapter. This chapter will then discuss the research methods of ethnography and Appreciative Inquiry (AI), of which semistructured interviews was the main tool that was used. Both ethnography and AI emphasise the importance of context and place. This is critical for my research as they reflect on lifestyles in a developed world context, which could be seen as somewhat unique for the field of development studies. AI also takes an appreciative stance to research, looking for the good in the research context. Finally this chapter discuss how primary and secondary data was utilised.

\subsection{World View /theoretical perspectives:}

My research also takes a politically and economically Left position. Luetchford (2008) describes this as a discussion about exploitation, the power of multinationals and political calls for trade justice. I acknowledge this in various 
chapters, but am also looking to take more of an appreciative approach to the situation, and the potential of coffee social enterprises.

\subsubsection{Social constructionism}

This view believes that reality is socially created (Neuman, 2006). Critically, this worldview holds that knowledge and social action go together, so that developing an understanding of the world affects how we think and feel, but also how we act and behave (Reed, 2007). Once we know the world in a certain way, we act accordingly in ways that reflect and fit in with this knowledge (Reed, 2007). The hope then is that through raising awareness of the lifestyles of coffee farmers, and how consumption here affects it, people will act in a more ethical way for the benefit of those farmers. This will also help inform how perceptions of distant others are created by the society we live in.

\subsubsection{Critical theory}

A critical realist ontological perspective sees reality as shaped over time by social, cultural, political and economic processes and values (Lincoln \& Guba, 2000). Theorists of critical theory seek to challenge these social orders (Reed, 2007). History then plays a big role in the reality we live in today. Though this is an obvious statement, it is important when thinking about ethical responsibility in the coffee industry, and what it is today. One should be aware of colonialism and globalisation when looking at what the coffee industry is now-a global industry linking people together from all over the world. Exploitation of resource rich countries by the West plays a critical role in these processes, and therefore is an important consideration in my discussions

Critical theory aims to uncover non-explicit processes and relations, to communicate these findings to promote progressive social change, and to incorporate moral questions into this discussion (Murray \& Overton, 2003). This will fit well with my research, as the relationship between people in New Zealand and local farmers is not one that is immediately clear, but exists nonetheless. Non-explicit connections are also apparent between cafés and the communities they are placed in, and the individuals who live in these 
communities. Cafés as businesses have the potential to add to the social fabric of these communities in multiple ways. This relationship raises moral questions about our responsibility to coffee farmers, because how we consume coffee here can produce negative or positive outcomes. Encouraging the change consumption ethics and habits is something I aim to do through the communication of this research.

\subsection{Research methods}

I first encountered appreciative inquiry and ethnography in the development research paper that was part of my Masters Degree. They immediately seemed logical methods to be used to enable my research, and further research confirmed this. These next sections will look into the theory of AI and Ethnography in more depth.

\subsubsection{Appreciative Inquiry}

$\mathrm{AI}$ is a move away from a critical approach to scholarship (Ludema, Cooperrider, \& Barrett, 2001). The issue with critique is that it creates binaries which confines conversation and silences marginal voices, as well as eroding community, creating social hierarchies and contributing to cultural enfeeblement (Ludem, Cooperrider, \& Barrett, 2001). AI allows for context, and the decision making power of individuals. Watkins, Mohr and Kelly (2011) state that the new form of globalisation has made individuals and small groups more of a dynamic force. Individuals then, because of the globalised world we live in, can have more influence in addressing poverty at a distance. They must "now ask: Where do I fit into the global competition and opportunities of the day, and how can I, on my own, collaborate with others globally?" (Watkins, Mohr, \& Kelly, 2011). The individual agency is key in this research in discussing the agency of individuals, in businesses and as consumers, to make change in their local communities and for coffee communities in developing countries. AI "focuses on supporting people getting together to tell stories of positive development in their work that they can build on" (Reed, 2007). Essentially, AI is: 


\begin{abstract}
"A collaborative and highly participative, system wide approach to seeking, identifying and enhancing the "life-giving forces" that are present when a system is performing optimally in human, economic and organizational terms. It is a journey during which profound knowledge of a human system at its moments of wonder is uncovered and used to so-construct the best and highest future of the system" (Watkins, Mohr, \& Kelly, 2011, P. 22.)
\end{abstract}

My hope is that through the interviews I had with the individuals in the coffee companies is they would have gone away encouraged about the work they were doing, and were reminded that their everyday work is making change.

The five principles of AI are outlined by Reed (2007). The first is the constructivist principle, which argues that people's thoughts about the world are interpreted and constructed differently, which provides varying stories of what happens. Next is the simultaneity principle, which sees inquiry and change upon reflection as occurring simultaneously, not sequentially. The poetic principle is that people author their world continually, choosing parts of their story they find interesting or important-AI should help them in thisThe anticipatory principle is particularly important in New Zealand, because we as a culture can have a negative outlook on the present and the future. This was something to be careful of as the researcher, especially with how the interview questions were framed. Finally the positive principle argues that focusing on positive questions engages people more deeply and for longer. This principle believes that capturing peoples interest is an effective way of getting them involved in change.

In the interviews the action aspects of AI were not explored, instead the stages of discovery and dreaming were focused on. This research explored what these coffee companies were doing currently, rather than how they could be improved. This is in part because I did not feel qualified to discuss or suggest what these companies could do on top of what they were already doing. Perhaps this happened in discussions with Roskill Coffee Project, as they were newer to business than the others, but even then it was limited. 


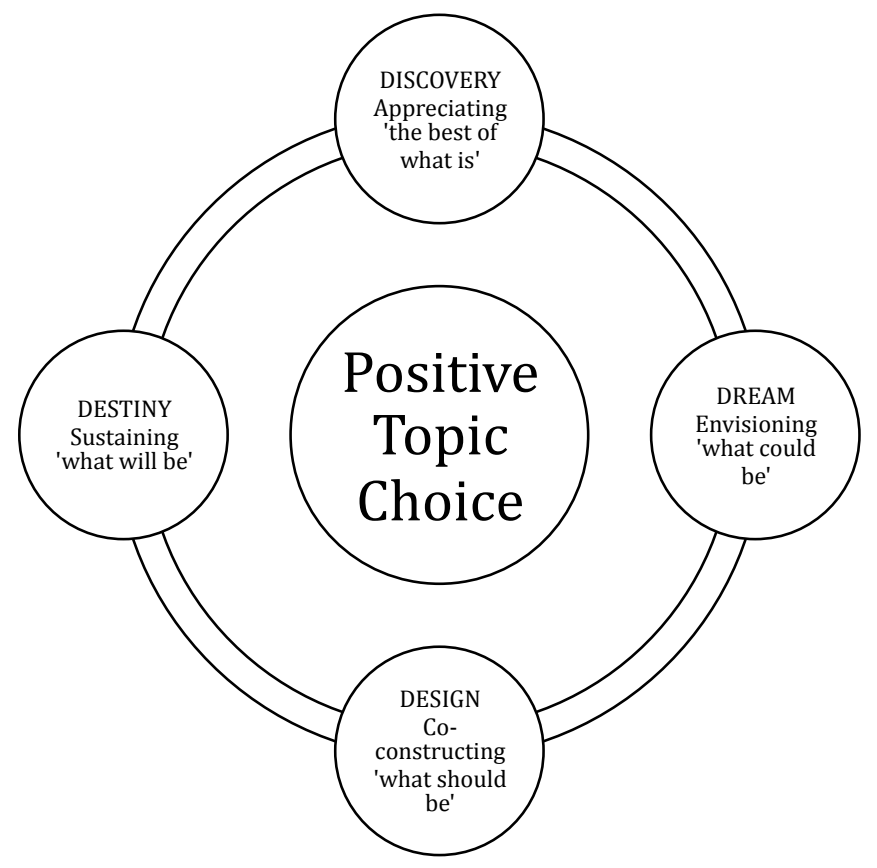

In reality AI was difficult to stick to in the interviews. Keeping the discussions positive, staying away from the negative, was a challenge. The situation the coffee companies are in, of trying to correct trade imbalances and acting ethically in the market is a challenging one, fraught with difficulty. So, although there is hope in what coffee companies have already done (and can still do), the people who are working in the industry are realistic about how much change they will see. Though the participants did have pride in what they do, and belief that it was making a change. They acknowledged the strengths of their organizations, whilst being realistic about what level of change they can make in the economy. This shows the importance of acknowledging issues or problems as catalysts for strength-based responses. AI is often used as a tool to solve organizational problems, in terms of their structure or culture. But in my research, AI is being applied to a context, namely the operations of supply chains, where there are no quick or easy solutions. Therefore to solely focus on the positives is to ignore the very context the coffee companies are working in. These problems must be acknowledged to see the good that is being done. 


\subsubsection{Ethnography}

This research also draws from ethnography, as it is concerned with the social setting that research is conducted in. Ethnography is grounded in a commitment to the first-hand experience and exploration of a particular social or cultural setting (Atkinson, Coffey, Delamont, Lofland, \& Lofland, 2007). It has its roots in anthropology and sociology, so is primarily concerned with social exploration, and the diversity and complexity of the social world (Atkinson, Coffey, Delamont, Lofland, \& Lofland, 2007; Reed, 2007). Social context is important in my research, as it involves researching development issues in a developed world context. As shown in my theory chapter, wealth and poverty are linked, so to address issues of poverty the field of development must begin to look at the lifestyles of the wealthy and how they affect development issues. This is especially pertinent when looking at consumption cultures in the West, and the affect this has on distant others in their context.

Researching in a developed context, though, does not just include looking at how western lifestyles negatively influence development issues. My research aims to look at how ethical consumption here in New Zealand can produce positive outcomes for distant others in the context of coffee social enterprises, and how 'doing development' may be possible in these companies. This is a specific context, and these ideas may or may not be transferable to other parts of western society. Nevertheless, there is potential to outwork ethical responsibility to distant others through coffee social enterprises.

Ethnographic methods utilize oral testimony, which emphasizes a researcher's ability to allow people to 'speak for themselves' and to construct their own texts, via recording and transcribing (Brockington \& Sullivan, 2003). One potential problem in interviews is that it can result in a one-way traffic of information from which only the researcher benefits (Brockington \& Sullivan, 2003). This could be seen as a problem in my research, but hopefully is mitigated by a summary of findings being provided to participants.

Ethnography, through its emphasis on the salience of culture and society in people's lives, has links with AI in its attention to context and place (Reed, 2007). This affects how people make sense of the world around them, and how their accounts of the world are constructed (Reed, 2007). Overall, "ethnographic 
approaches aim to be 'actor-oriented' in their attempts to convey reality from a subject's 'point of view', increasingly including those of the researcher as final author and editor of the ethnographic text" (Brockington \& Sullivan, 2003). My research has a clear bias to representing only a select few views in this field of research, namely the owners, managers, and roasters of coffee companies.

There have been some critiques however, as outlined by Brockington and Sullivan (2003). Post-modern critiques of ethnographic methods have asked whether researchers have the right or are able to speak for a group's identity and authenticity, especially with the inequalities that are frequently implicit in the relationships between researcher and researched. Also, as ethnographic techniques are solely based on writing practices, it leaves any observation reduced to being communicated through texts. These texts can then be deconstructed to contribute to discourses in many different ways, outside of the control of the author. Speaking on behalf of others becomes particularly problematic in this research, as I will not be speaking directly to the coffee farmers. I will be interviewing people from New Zealand that work for the coffee companies and will be representing the coffee farmers. This places them in the privileged position of speaking on behalf of the farmers.

\subsection{Secondary data collection}

Central to this thesis is connecting theory with practice, particularly applying the development discourse to the coffee social enterprise industry in New Zealand. Research on post-development theory, the economy, the coffee industry and social enterprise was an important part of this. My main theory chapter on post-development was completed before primary data collection began. From then on, any research done was to fill perceived gaps that required supportive evidence whilst writing the discussion chapters from the primary data. 


\subsection{Primary data collection}

\section{$\underline{3.6 .1 \text { Interviews }}$}

In-depth interviews were my primary method of gathering primary material, using a semi-structured method. The interviews were a learning process, as it was my first time doing serious interviews. There were many lessons learnt and improvements made as they were conducted. The data obtained in these interviews have been included in my discussions from chapter four onwards.

Table 1: Research participants

\begin{tabular}{|l|l|l|l|}
\hline Participant & Company & City & $\begin{array}{l}\text { Interview } \\
\text { location }\end{array}$ \\
\hline Nigel Cottle & Crave Café & Auckland & Crave Café \\
\hline Rowan Johanson & $\begin{array}{l}\text { Roskill Coffee } \\
\text { Project }\end{array}$ & Auckland & $\begin{array}{l}\text { Roskill Coffee } \\
\text { Project }\end{array}$ \\
\hline Matt Lamason & Peoples Coffee & Wellington & His home \\
\hline Rene Macauley & Peoples Coffee & Wellington & $\begin{array}{l}\text { Peoples Coffee, } \\
\text { Constable Street }\end{array}$ \\
\hline Mike Murphy & Kokako Café & Auckland & $\begin{array}{l}\text { Kokako Head } \\
\text { Office }\end{array}$ \\
\hline Adrian Palmer & Addington Co-op & Christchurch & Addington Co-op \\
\hline Brook Turner & $\begin{array}{l}\text { Zeal Youth } \\
\text { Organisation }\end{array}$ & Auckland & $\begin{array}{l}\text { Wellington } \\
\text { Airport }\end{array}$ \\
\hline
\end{tabular}

The choice of interview participants was a mix of personal choice, advice from acquaintances and industry experts. I am involved somewhat in the Wellington coffee community, particularly with cafés that have strong ethical values. This made gaining connections with other coffee companies easier, but also made my choices preferential. I have a long-term interest in these types of organization, which has drawn me to research with them. All interviews were conducted with people within the coffee industry, apart from Brook Turner. I chose to do an interview with him because of his extensive experience with, and expertise on, social enterprises. Contact with the majority of participants was 
via email at the start of 2014. All participants were immediately willing to take part in the interviews and share their opinions, so there was no convincing that needed to happen. The only difficulties were organizing times to meet.

Coming up to the interviews, there were definitely perceptions I had which influenced how the interviews were conducted. The participants were people who have worked in the coffee industry for a long time, some up to 10 to 15 years. Because of this, I quickly became aware of how little I knew about the coffee industry. My preconception then was to enter the interview as someone who had nothing to offer these professionals. As stated earlier this perception limited my use of AI in terms of creating new ideas for the organization. The interviews were held in a variety of places: cafés, offices, homes and airports. There did not seem to be any direct influence on the interviews from having them in different settings, other than issues of noise. Perhaps the interviews held in homes or offices had a more relaxed feel than when the interviews were conducted in busy cafés, but that is all.

Due to only conducting an interview once or twice in the past, and never by myself, there were many lessons I learnt in the first interview. I immediately realized that my interview questions were very removed from the reality of the situation. I was asking theoretical questions about ethical responsibility and development of the manager of a café. For the most part, I abandoned the questions I had created. I found that these questions restricted the discussion, when it wanted to naturally move in other directions. From then on I stuck to the themes of personal motivations and values, appealing to the customer and their agency, and ethics in the market, as opposed to specific questions. With these ideas in mind, I asked questions that seemed appropriate for the situation, and which would lead to deeper discussions into that topic. For the most part, this was very successful and highlighted the intuitive nature of this process. Often the discussion felt as though it was going off topic, but would then move onto subjects that were quite pertinent. The way I asked questions changed over time, as I found I often softened questions at the start, but later was more comfortable asking more pointed questions and waiting for the answer. Allowing silence, and giving the participant time to think became increasingly apparent as an important tool. 
My original intention was to discuss the ethical responsibility of consumers to distant others. But through doing interviews with managers and roasters at coffee companies, instead of consumers themselves, the material that was gathered through these interviews altered this. My conclusions do consider how to appeal to consumers' ethics, but that is from the perspective of the coffee companies. Also, due to some of the cafés strong focus on local communities, a new dimension of interacting with 'distant others' in ones own community arose. This shows that some original intentions I had with my thesis changed or were redirected because of the data that was gathered.

\subsubsection{Case study approach}

Case studies place an emphasis on the contemporary nature of a phenomenon, it's 'real life nature', and the fact that the phenomenon is ultimately connected to the context it is researched in (Reed, 2007). It treats the phenomena being researched as a distinct entity or case and explores it in the context where it occurs (Reed, 2007). Each coffee company has provided different perspectives and outworking of their values. Whereas some had a strong focus on the caring for local farmers (such as Peoples Coffee), others had a hyper local focus (such as Crave café). These different emphases show the myriad of expressions that social enterprise can take.

\subsubsection{Analysis of data}

I decided to transcribe my interviews fully, and to do it myself for a number of reasons. Firstly, it was a good way for me to become familiar with the material that I had gained in the interviews. Secondly, since they were in depth interviews it was important to capture all the material, and to have verbatim quotes. Although I was listening intently at the time, there was much content that I had not taken in, so it was important to go back and retrieve it. One difficulty I came across was how to type out, grammatically, what people were saying. This meant that I had to interpret the material, and write it in a way that seemed logical to me. This means that the material has been viewed through my lens, and could not be seen as material direct and pure from the participant. 
In terms of the use of the data collected through the interviews, I tried to have the participant's opinions apparent throughout this thesis (apart from the theory chapter). Large quotes are used where relevant.

\subsubsection{Ethical considerations}

Ethical considerations seemed to be less of an issue due to the context of my research, but are nevertheless important to discuss. Through the Ethics Approval process I was forced to consider the implications of my research, which helped me to gain perspective on my research as not just an individual piece of work, but something that contributes to wider academia. At the beginning of each interview I had the participants read the Participant Information Sheet, and to read and sign the Consent Form (these are attached). I gave the participants the choice to be named; whether they would like a recording of the interview either within a week or at the conclusion of the project; the assurance that the data will not be used for any other purpose; and finally, supplying them with a summary of the results at the end of the project. One participant required their recording to be given back to them; all participants wanted a summary of the findings of the research; and one asked specially for their transcription to approve its validity.

All my participants were willing to be named in my thesis, so identification was not a problem. Perhaps this could have been an outcome from doing an Appreciative Inquiry, as I was attempting to find the good in the organisations, which may have made the participants more willing to be identified.

\subsection{Journaling}

This has been an important part of my research, as it has helped me to clarify ideas, and provided an opportunity to reflect. It was particularly helpful after I had conducted the interviews, as I was able to write all my thoughts down immediately. I reflected on what went well, what did not go well, and any key points I could recollect. Interestingly, the longest entry was after my first interview, which is the interview I thought went the worst. There were many 
aspects of the interview, such how I was constructing my questions and leaving pauses for the interviewee to respond, which I was eager to learn from, and change in future interviews.

\subsection{Research Limitations and Opportunities for further research}

One limitation of my research is that I did not interview consumers. This meant that I did not obtain their motivations for going to these companies. More research could be done with those who patronise the cafés, to understand how they are responding the social enterprises marketing approaches and how they appeal to people's ethics. It would also be beneficial to look further into the real impacts of these social enterprises in developing countries and here in New Zealand. For the most part, I was taking the word of the coffee companies on the impacts of the work they do, so to have objective research on the impacts would help round out studies on these companies. I intentionally remained removed from the coffee farmers and the production end where these companies work to focus more reflectively on the West. Connecting this research to research on fair trade, co-operatives and more quantitative research on social enterprises would be invaluable.

\section{9 summary}

This chapter has discussed the methodology and research methods that have been used in my research. Firstly, it has discussed my positionality and the context of this research. These two are interwoven, as the research context is also my home context. This embeds me in the issues raised by the research, but also the potential solutions it recommends. It also reveals a unique reflective aspect to this thesis. I have used post-development as my theoretical perspective, which has been discussed. This research has also utilized critical theory and social constructionism. My two research methods were ethnography and Appreciative Inquiry, within which semi-structured interviews and case studies were used. These helped to take an appreciative stance to the research around coffee social enterprises, and to be aware of the affects of context and 
place. Finally, the use of primary and secondary data in this thesis has been discussed. 


\section{Chapter Four}

\section{Transitions in Capitalism and the Market: A New Space for Ethical Business?}

\subsection{Introduction}

"It seems that business is a major contributor to the problems we and our planet face. But can it also be a critical vehicle for change? Could business direct new wealth toward planetary well-being?" (Gibson-Graham, Cameron, \& Healy, 2013, p.51).

This chapter will discuss the global economy, which is the context for this research on coffee social enterprises. Gibson-Graham et al. (2013) show well here the notion that although businesses have caused damage to the world they can also be used to achieve positive development outcomes. This chapter will look at this dichotomy, by first outlining the context business works in, namely the global economy, and some of the issues within it. It takes a critical view of neo-liberal policies; it does not reject capitalism outright, but promotes a reframing of the economy, and business within that.

This chapter will begin by looking at two different models of doing development in the market. These can be defined as the traditional development-as-growth model, and then economic work with explicit social aims, which is what is promoted here. It will also look at the dynamic between ethics and economics. Social ideas have not fitted well with economic ideology, particularly when looking at ideas of growth and scarcity. Misconceptions about the 'level playing field' are also pervasive, and are disconnected from the reality of how the supply chain works. Recently, though, there has been an ethical turn that has sought to correct some of these issues. It provides an avenue for postdevelopment practice to be outworked in the economy, of which social enterprise can be a part. There are limitations to this and how ethics can be outworked in the economy, which were made clear by the participants, and will 
be discussed in this chapter. Again it should be noted that primary data is used in this chapter, and has helped inform its content.

\subsection{Development in the market}

The global economy, and how development is done (and can be done) through this is the context for this research. Sachs (2010) states:

"On the one hand, there are those who implicitly identify development with economic growth, calling for more relative equity in GDP. Their use of the word 'development' reinforces the hegemony of the economic world-view. On the other hand, there are those who identify development with more rights and resources for the poor and powerless. Their use of the word calls for de-emphasizing growth in favour of greater autonomy of communities" (p.x)

The second of these is what I focus on, as it provides a new way to engage with the market and seek development outcomes. The traditional economic development model of development-as-growth is not the form of development I propose, as it has not been successful in alleviating poverty, and therefore connotes a negative response to the idea of development and economics. There is a danger that this research could be connected with this mainstream type of development. Indeed, development and capitalist economic growth are assumed to be indivisible (King, 2008). This is the ubiquitous, one-size-fits-all development paradigm that post-development theorists find so objectionable (King, 2008). If anything the research rejects this model, and attempts to find alternatives through applying post-development to these coffee social enterprises.

\subsection{Traditional views of development in the market}

"People still have this idea that the market is an even playing field that people trade based on wants and needs, and whoever's got the best price with the contingent quality makes the sale, and who doesn't it's due to their own failure to be good enough. When in fact it ignores... the fact that the market isn't a level playing field... And I 
think even today most people take umbrage when you talk about trying to pay some farmers more through deliberately bias towards some farmers, because they don't think it's fair. And kiwi's have a real innate sense of fairness. So I just think there's a lie that is pervasive in our purchasing, in our consumer culture. It works really well for the consumers in the West, it works terribly for the producers of low price product" (Lamason, interviewed $18 / 06 / 2014)$.

Here Lamason highlights his perception of some of the misconceptions apparent in society about the global economy. In the economy, market dynamics of supply and demand are portrayed as naturally operating, which is able to efficiently allocate resources due to its level playing field (Gibson-Graham, Cameron, \& Healy, 2013). Indeed, the market "is not considered merely as a technical device for the allocation of goods and services, but rather as the only possible way to regulate society" (Berthoud, 2010). This shows there is a deep held belief that the market has the power to solve the world's development problems (Berthoud, 2010). Within this, business has been viewed as the "font of economic growth from which wealth and well-being flow", but for the most part has not been organised around the greater good (Gibson-Graham, Cameron, \& Healy, 2013).

Some argue now, though, that the period of growth in society is coming to an end (see Wolf, 2012). Sachs (2010) states the desire for equity is largely fixed on development-as-growth, and it is this model which strains human relations and fundamentally threatens the environment. But this model has also created, or reinforced, global inequality. Sachs (2010) states the "shiny side of development is often accompanied by a dark side of displacement and dispossession; this is the reason why economic growth has time and again produced impoverishment next to enrichment" (p.x). Indeed, much of development has unjustly marginalised the very places coffee comes from (such as Chiapas, Mexico, as shown in King, 2008).

Key to economics is the idea of scarcity and how to deal with it. It connotes shortage, rarity, restriction, want, insufficiency and frugality (Esteva, 2010). These ideas place a reductive lens on life, and again create the need for 
continual growth. This has become a dangerous basis for life, both environmentally and socially, and needs to be tempered. Gibson-Graham et al. (2013) agrees that economic growth has been at a massive cost to the environment, and has not been equally distributed across the board. What is needed is an appreciative stance that acknowledges opportunities and value outside of economic wealth.

When discussing coffee and development in the economy it is important to understand the supply chain. Gibson-Graham et al. (2013) state:

In our globally connected world, a large proportion of the products we consume comes from a great distance. But when we acquire what we need from distant others via the market, the nature of our encounters is masked (p.86)

The supply chain is organised around a division of labour based on the following independent agents: producer, primary processor/middle person, exporter, international trader, industrial processer, wholesaler, retailer and consumer (Daviron \& Ponte, 2005). Throughout this, the aim is to buy products as cheaply as possible, and then sell them at a higher price, thus making a profit through exchange (Luetchford, 2008).

The economy is something governments and international organisations have utilised for development since World War II. The relation between commodity trade and development has been the subject of debates and analyses for several decades (Daviron \& Ponte, 2005). Up until the last 20 or 30 years, with the movement of participatory development, economic development predominated. The following table shows the historical debates on commodity markets and development:

Table 2: Historical debates on commodity markets and development (Daviron \& Ponte, 2005)

\begin{tabular}{|l|l|l|l|}
\hline $\begin{array}{l}\text { Debate and } \\
\text { period }\end{array}$ & $\begin{array}{l}\text { Development } \\
\text { problem }\end{array}$ & Key indicator & $\begin{array}{l}\text { Main causes of } \\
\text { problem }\end{array}$ \\
\hline $\begin{array}{l}\text { Structuralism } \\
(1950 s-1970 s)\end{array}$ & $\begin{array}{l}\text { Import capacity; } \\
\text { Wealth of }\end{array}$ & $\begin{array}{l}\text { Terms of trade } \\
\text { (ratio of export }\end{array}$ & $\begin{array}{l}\text { Unlimited supply } \\
\text { of labour; Price }\end{array}$ \\
\hline
\end{tabular}




\begin{tabular}{|c|c|c|c|}
\hline & $\begin{array}{l}\text { countries } \\
\text { exporting primary } \\
\text { commodities }\end{array}$ & $\begin{array}{l}\text { unit value/import } \\
\text { unit value) }\end{array}$ & $\begin{array}{l}\text { inelasticity of } \\
\text { demand }\end{array}$ \\
\hline $\begin{array}{l}\text { The counter- } \\
\text { revolution in } \\
\text { development } \\
\text { economics } \\
\left(1980 s^{-}\right)\end{array}$ & Rural poverty & $\begin{array}{l}\text { Ratio of farmer } \\
\text { price/export } \\
\text { price }\end{array}$ & $\begin{array}{l}\text { Direct and } \\
\text { indirect taxation; } \\
\text { State intervention } \\
\text { in markets }\end{array}$ \\
\hline $\begin{array}{l}\text { Neoliberal trade } \\
(1980 s-)\end{array}$ & $\begin{array}{l}\text { Export incomes of } \\
\text { countries } \\
\text { exporting } \\
\text { agricultural } \\
\text { commodities; } \\
\text { Rural poverty; } \\
\text { International } \\
\text { inequalities }\end{array}$ & $\begin{array}{l}\text { Amount of } \\
\text { subsidies by } \\
\text { export unit or } \\
\text { production unit; } \\
\text { Barriers to trade; } \\
\text { Ratio of farm-gate } \\
\text { (or export-level) } \\
\text { price to consumer } \\
\text { price; Levels of } \\
\text { oligopoly }\end{array}$ & $\begin{array}{l}\text { Unfair trade rules; } \\
\text { Agricultural } \\
\text { protectionism in } \\
\text { developed } \\
\text { countries; Market } \\
\text { power of traders, } \\
\text { processors and } \\
\text { retailers }\end{array}$ \\
\hline
\end{tabular}

There is generally a lack of knowledge or understanding, among business and consumers alike, of what goes on throughout the supply-chain. There is also a fallacy that if a company's product is doing well, than the entire supply chain is benefiting financially. Daviron \& Ponte (2005) argue that many developing countries are stuck producing and exporting goods that are valued for their material quality attributes, whereas symbolic and in-person service quality attributes are generated and controlled elsewhere. But with coffee, there is a huge amount of value added by farmers in the production process. Often this work is not understood or recognised. Misconceptions about this, and the economy in general, are changing slowly but education is still a key aspect of the social enterprises work and needs to continue. 


\subsubsection{Business criticism}

Lamason (interviewed 18/06/2014) argued that because of the way most businesses are set up, they are unable to address ethical issues as they are often designed with a lack of knowledge of poverty and the effect the market has on producers. To Lamason (interviewed 18/06/2014) this was particularly true for big business. He stated:

"I am sceptical of big business and it's ability to make substantial change. I do think there's just a lot of value in more small, and less big. It's easy to trust big who can say things loudly into a great audience, and say it nicely, that's what marketing can do. But whether there is that supply chain integrity where margins are actually being passed on to the producers, and where that's verifiable, and that fact is somewhat at the heart of the whole supply chain. So from the price that we're getting from our consumer, we're aware that we have to be charging this sort of price, if we want to be paying a good price to the producer" (Lamason, interviewed 18/06/2014).

Again this touches on the disconnect that goes on in the supply chain, but also the distrust many of the participants showed towards big business. The implementation of a deregulated free market, privatised public services and a liberalised economy has put corporations right at the centre of public concern (Visser \& Matten, 2007). And in the coffee industry there is a tendency towards corporations holding a monopoly in the market (Fridell, 2007). Participants were suspicious of the ethical changes big business (such as Nestle or Cadbury) purported to make, and generally assumed it was green-washing. This refers to a company saying they are acting in a socially ethical, or environmentally sustainable manner, but in reality not actually changing anything. Participants were more supportive of small business (which all of their companies were), as they felt they have more integrity. There were sacrifices that came with this, in terms of profit margins and market coverage, but they believed that this was a better model. 


\subsubsection{Ethics and economics}

Gibson-Graham et al. (2013) argue the two beliefs that dominate economic actions are: growth at any cost is good; and private enterprise is the way individuals can apply their energy and creativity to generate wealth. The problem with this is that economic actions have lost, or maybe never had, "a moral compass to guide [them] so that they reflect care and responsibility for one another, for living beings, and for our environment" (Gibson-Graham, Cameron, \& Healy, 2013, p. xviii).

It also became clear in the interviews that working in a socially minded way in the economy meant going against deep-seated ideological ideas. Esteva (2010) agrees that "economics strives to subordinate to its rule and to subsume under its logic every other form of social interaction" (p.14). Luetchford (2008) argues that market capitalism and the invisible hand make the economy impersonal, meaning that the only economic imperative is self-interest. So to have social ideas in the economy is very difficult. This shows how embedded economic ideology is in New Zealand society, but also how the faults in the system are ignored, or deemed to be too big an issue. There is still the belief that the market is a level-playing field; that everyone has equal opportunities to thrive economically. Luetchford (2008) agrees the belief is that trade is fair because it provides everyone with equal opportunity; "the morality lies in the impersonality" of being treated the same (p.153). Everyone is a part of the "democracy of consumers" (Gibson-Graham, Cameron, \& Healy, 2013, p.85). Economic ideology, in this case, is held on to over the reality of the situation. In reality, the economy excludes or marginalises many people. It ignores social processes, and what different endowments and capacities people bring to the market (Luetchford, 2008). Fridell (2007) makes it clear:

The global economy cannot and will not bring development benefits to the world's poor unless strategies are pursued which seek to counter or combat neoliberal policies and place the enhancement of human life, not merely economic growth, at the centre of development (P.277). 


\subsection{New forms of development in the market}

A different way to work through the market therefore, and what is promoted here, is development done through companies that have explicit social aims, and have had these from the beginning. Because their formation as a company is based on ethical values, they have the ability to outwork development outcomes and produce positive outcomes for the less privileged. One critical point that Macauley (interviewed 11/06/2014) made, in regards to whether business could be used for development, was that it works "only if the people that are being developed are in charge of it. I don't think business should be involved in development when it's outside of the peoples' hands that are being developed" (interviewed 11/06/2014). This is a fundamental difference to traditional economic development. Neo-liberal policies are often imposed on peoples or countries in the name of development, and disempower those people more than anything. But with this model, which requires handing over the reins to a degree, the people gain dignity and autonomy through having more power in their economic decision-making. This model supports small business over big. It also links to Sally Matthews' idea of supporting popular initiatives, as outlined in the theory chapter.

Gibson-Graham et al. (2013) proposes the idea of 'taking back the economy'. They describe this as surviving, distributing surplus, encountering others, consuming sustainably, caring for commons, and investing our wealth in future generations (Gibson-Graham, Cameron, \& Healy, 2013). This is a key idea when discussing development engaging in the economy in a bottom-up model, utilising post-development principles. This process can personalise business and economic relations. Adam Smith is well known for his theory of the invisible hand that would guide market mechanisms to promote prosperity for all (Mulgan, 2006). But he also wrote on the 'moral sentiments' of sympathy and compassion, which hold societies together (Mulgan, 2006). Mulgan (2006) argues that this could create another invisible hand that could channel these "moral sentiments, the motivations of care, civic energy, and social commitment into practical form and, thus, into the service of the common good" (p.75). This shows the importance of connecting economics with social considerations, and provides a basis for the work of business that incorporates considerations of 
others. This in turn provides an opportunity for post-development practice to be outworked.

\subsubsection{Ethical turn in the economy}

The economy is witnessing an ethical turn, which in large part is driven by the demands of ethical consumption. Lewis (2012) states the rise of ethical consumption connects to a broad popular critique focused on a range of concerns around environmentalism, anti-materialism, and unsustainable lifestyles. She goes further that terms such as 'responsible' and 'conscience consumption' are increasingly entering into the everyday language and practices of so-called 'ordinary' consumers (Lewis, 2012). The raised awareness of individuals are signified by, and in part due to, documentaries such as $A n$ Inconvenient Truth, Super Size Me, Black Gold and Bitter Chocolate: The Dark Side of the World's Most Seductive Sweet and Blood (Lewis, 2012). This ethical turn also implies the economy can be altered through ethical decision-making by individual consumers. Examples such as the Fair trade movement (which will be discussed more later), or keeping blood diamonds out of circulation, show that the market "can be regulated to take account of our interconnections with distant others" (Gibson-Graham, Cameron, \& Healy, 2013, p. 99, emphasis in original). The Conscious Consumers network is also an example of this (www.consciousconsumers.org.nz).

Because of this consumer movement, the business sector is being influenced as well. Since the end of the Cold War and the advent of globalisation, businesses "have faced growing demands to address issues of societal concern and to be responsible and accountable members of our global society" (Visser \& Matten, 2007, p. ix). Businesses could be blamed for some a-moral actions in their activity (Goldman Sachs' operations are described as such in Nocera, 2012), but there is a shift that is happening. There is the realisation that acting ethically and sustainably is the future of business. This is shown by terms such as 'ecosystem' now used to describe the workings of the economy (Gansky, 2014). 
This ethical turn seeks to engage capitalism, as oppose to rejecting it and promoting some another world system. It recognises that unethical behaviour has occurred through the market, and that this can, and should be rectified. The companies use the supply chain and continue to trade globally, but do it responsibly. Lamason (interviewed 18/06/2014) states:

"The power of industry for me is very exciting, cause there's so many options. And it's not about making more money or getting rich, which is what most people think when you get into business is the reason for, but it is about being able to keep all your values and have your own sovereignty, and weave that into what you're gonna do, which is what I do with Peoples."

As stated in the post-development chapter, many suggest global trade is unethical and should be rejected outright. But if there is to still be access to a commodity like coffee, avenues such as fair trade and social enterprise need to be utilised.

This ethical turn can be seen in the engagement with fairly traded goods. In 2004, Fairtrade (FLO) retail sales reached \$NZD 261,050 (Fairtrade AUSNZ, 2011). In 2010, retail sales reached \$NZD 45.4 million (Fairtrade AUSNZ, 2012). Globally, consumers in 2011 spent \$NZD 8.8 billion of FLO certified goods, a 12\% increase on 2010 (Fairtrade AUSNZ, 2012). It should be noted that this ethical turn, in New Zealand at least, is particularly popular in the main centres (Wellington, Christchurch and Auckland). So it could be argued that the reach of this ethical turn is limited. Nevertheless, there are pockets of industry and enterprise that are beginning to work from an ethical or social basis. Indeed there are products with FLO mark that are now available in 120 countries (Fairtrade AUSNZ, 2012). The coffee industry is one area where this ethical turn is occurring. It is particularly popular in small boutique coffee circles. These companies have chosen to engage ethically in the supply chain to make it as credible as possible, as opposed to doing whatever it takes to make ends meet. For these companies profit at any cost is no longer the goal. The goal is to achieve equitable outcomes for each part of the supply chain. Within this is a new perspective that profit produced by a company is not solely for the people 
at the end of the supply chain, but that it should be distributed evenly. This is the model adopted particularly by Addington Co-op.

\section{$\underline{4.6 \text { Limitations }}$}

There are clearly limitations to working ethically, and doing development through the market. Much of the talk around this does take a romantic view, of returning back to a time where production and consumption were connected (Luetchford, 2008). Lamason (interviewed 18/06/2014) made it clear that "we can't buy our way to change", nor can we "consume our way to a better world". What this means is that overconsumption and excessive purchasing are issues that contribute to inequality-just encouraging people to do it ethically may not solve the negative effects that they create. Working through the market, the overarching goal of the market is to gain wealth. To succeed in the market is to prosper financially. Sachs (2010) argues that through the process of colonisation "the world hopes for the future are fixed on the rich man's patterns of production and consumption" (p.ix). So in working through the market, the assumption is that one is working to gain as much wealth as possible. This is not the case for social enterprise, as they will not do whatever it takes to gain wealth, and will often give away the profit they do gain. And ultimately this is one goal that social enterprise is trying to undermine. Nevertheless, it is important to communicate this, as gaining wealth is an assumed part of the economy, and having other motivations for being in the economy (such as social aims) will take time. This is something that the development field knows well, that investing financially into a situation does not necessarily solve everything. Turner (interviewed 25/06/2014) also stated "there's always going to be a negative effect, it's the world of scarcity that we live in. There will always be a negative effect of business no matter what that business is".

The market is also a difficult place to work in, in terms of having entirely ethical practice. It is nearly impossible to purchase ethically everything that is needed to run a business, let alone what it would entail purchasing ethically for an individual's lifestyle. Often, to hold up ethical values means going against the majority view in business, which can be difficult to maintain. And then as 
consumers it can be difficult as well. Lamason (interviewed 18/06/2014) states:

"What I'm saying is that there are just limited options because world trade is dominated by big players in virtually every segment of the market for cotton through to food through... Anywhere where you've got small producers producing the product, the people that control that product hold and control the majority of that market. That doesn't have to be a downer message, but it is one that doesn't put our faith in the market to fix things."

It should be said as well that not all the participants saw themselves as outworking social justice. Cottle (interviewed 26/06/2014) for instance, stated that Crave is not actively addressing systemic injustice, but were rather looking to make the community in Kingsland a better place. He described this as being for social advancement, rather than social justice. This speaks to the social capital that these coffee companies can produce, which will be discussed further in later sections.

It is important to consider these points and be reminded that there are limits to what can be done. But as Appreciative Inquiry shows there is great possibility for individuals as part of companies and/or as consumers to make change in specific contexts. This acknowledges the structural inequality in the market, but also gives hope that the status quo can change.

\subsection{Summary}

This chapter has sought to highlight the operations of capitalism that have contributed to inequality. Development solutions in many forms have been attempted through the market throughout history. For the most part it has not been successful. But by adopting an approach to business that includes ethical considerations, seeing it as a way of 'doing development', it can engage with the market and seek to bring more equity to market exchanges and broaden those who benefit from the market. This promotes engaging with capitalism and altering it, rather than rejecting it outright. This is what coffee social enterprises aim to do, and what I propose development can do through social enterprises. 
In taking back the economy, Gibson-Graham et al. (2013) encourage recognising the diverse economy, which is the foundation for building community economies. These include alternative capitalist enterprises, which are a mix of mainstream economy and alternative economies (Gibson-Graham, Cameron, \& Healy, 2013). An example of these includes businesses that are driven not by the goal of turning a profit, but by a commitment to producing social or environmental wellbeing (Gibson-Graham, Cameron, \& Healy, 2013). Social enterprise overlaps both business and charity, and creates a new space to do development. The next chapter will look further into this. 


\section{Chapter Five}

\section{Business as a Social Enterprise in the Fair Trade Coffee Industry}

\section{$\underline{5.1 \text { Introduction }}$}

"Just seeing the empowerment that businesses can bring to people who would otherwise be at the mercy of the job market, or at the mercy of Work and Income, or anything else. And that's what you see, that's what power is for co-ops or the small handcraft that Trade Aid work with, is that they're not making heaps more money than they would probably if they were working for the man, but their lives are hugely more dignified. And they get way more say in how their lives turn out, than when they work for the man. I think that's an incredibly powerful part of being in business" (Lamason, interviewed 18/06/2014).

This chapter will look at social enterprise, and the impact this model can have in the coffee industry when applied to coffee companies. Social enterprise fits into the ethical turn that is occurring in parts of the market, as shown in the previous chapter. As an entity, social enterprises marry business and charity by connecting ethics with profitability. They aim to have a positive social impact and contribution, and often work for the good of disadvantaged people. The impact of social enterprise on the coffee industry is two-fold. First, it can impact the process of trading internationally through encouraging models that promote people's well being. Second, coffee social enterprises can impact the local communities where they are based in their home country.

This chapter will begin by discussing the coffee industry and fair trade. These are both big topics so these sections can only hope to give a brief outline. Although the coffee industry has had a history of inequality, it also includes a history of café culture that has played a part in progressive social thinking. Next, social enterprise will be defined, and the social enterprise continuum that 
Turner (interviewed, 25/06/2014) created will be discussed. The final two sections will look at the impact coffee social enterprises can have on an international scale, and then what impact they can have in a context such as here in New Zealand. Social enterprise can encourage the humanising of the supply chain on a global scale, and in doing so consumers encounter 'distant others' in their purchasing. Locally, social enterprises can address issues of inequality and poverty here in New Zealand, as much as they do in a developing country. In doing so they make a contribution socially to the community they are a part of.

\section{$\underline{5.2 \text { Social enterprise }}$}

"If we made equality, equity and well-being the aim; and if we put business through that lens as much as we could; and if we made sustainability and self-generating funds the aim; and we put charity through that lens-then I think we would have a more holistic society where my [Zeal Youth Organisation] model isn't bastardised cause I have to take money from gambling trusts to do good work. And a business isn't bastardised, just to make a profit and pay their staff and make ends meet, they have to exploit the poor. If we can find some new ways that work, which I guess is what social enterprise is trying to do, that can be the new development" (Turner, interviewed $25 / 06 / 2014)$.

As alluded in this quote, social enterprise as an idea provides an opportunity for those using it to outwork ethics in the market. It also provides a means to outwork alternative development approaches, and provides useful insights into how business and charity can be done differently. This section relies on an interview conducted with Brook Turner, the CEO of Zeal Youth Organisation. Social enterprise as a model was not the original way that I defined the coffee companies I wanted to interview. I just saw them as companies that had ethical values. Nor did the companies immediately define themselves as social enterprises. This idea came from discussions with Turner (interviewed 25/06/2014). It became clear that it was a useful framework to categorise the companies that I was interviewing. 


\subsubsection{Social enterprise defined}

Social enterprise is a contested term, which can mean many different things (OECD, 2000). Social enterprise is broadly defined as the use of nongovernmental, market-based approaches to address social aims (Kerlin, 2006). It can be linked to other ethical movements, such as Corporate Social Responsibility, which aim to bring more accountability and responsibility to business, as well as to government and charities (For more information see Visser, Matten, Pohl, \& Tolhurst, 2007). This creates a merging of the structures and values of business and charity. This means that it has multiple bottom lines of working for profit, but also working for social aims. So business would be viewed through an ethical or equitable lens, and charity would be seen through and entrepreneurial lens. Macauley (interviewed 11/06/2014) stated that it is adding value back to society, through expenditure on luxury items, such as coffee.

Fundamental to social enterprise is reconciling the economic and the social, encouraging alternative entrepreneurship and the promotion of new social cohesion (OECD, 2000). After all, market interactions occur, for the most part, through social interactions (Arrow, 2000). This can promote economic and social well-being, and is a part of a new form of capitalism that recognises a more varied economy or as Gibson-Graham et al. (2013) call it, a community economy. Frances (2008) describes it as value-centred market economics. This is a space of decision-making in which we negotiate our interdependence with other humans, other species, and our environment (Gisbon-Graham, Cameron, \& Healy, 2013). It can operate within the existing structures and mechanisms society that already has (France, 2008). This social cohesion creates 'social capital', as well as financial capital. Definitions of social capital vary, as well as the situations its is applied to (Dasgupta \& Serageldin, 2000). But Dasgupta and Serageldin (2000) argue that social capital is an economic good, as it is an important ingredient to resource allocation mechanisms.

There are three aspects or dimensions of an organisations structure that can be affected by the ethical changes that social enterprise requires: the product or service provided by the business, what is done with its profit, and the staff employed in the organisation. These are changed to varying extents in 
different organisations. Where the coffee companies that I did interviews with placed themselves will be discussed in the next chapter. Turner (interviewed 25/06/2014) usefully created a social enterprise continuum to help illustrate these different stages of organisation change between business and charity.

\subsubsection{A new space for social enterprise in society}

The delivery of goods and services can be loosely divided up into three sectors: the business sector, the government sector and the charity sector. It could also be divided into the public and private spheres (business and charity being in the private sphere). These are not only literal divisions, but also mental divisions in people's perceptions of these different spheres of society.

There are overlaps between these sectors- for instance the government regulates the business sector, and charity relies on government assistance or private donations, for instance-but in terms of their organisational make-up, they operate differently. Frances (2008) states that the Left (where many charities would be placed) has focussed on social values, whereas the Right (where business would fall under) has focussed on the management of the economy. These elements, although part of the same system, operate quite separately (Frances, 2008). This is particularly true for business and charity. But now, social enterprise is rising as a fourth sector that overlaps between business and charity. It even has the potential to connect economic and social policy in government (Frances, 2008). Turner (interviewed 25/06/2014) argued that here is a wide-open space of opportunity that social enterprise creates.

\section{$\underline{5.2 .3 \text { Social enterprise continuum }}$}

This continuum was created by Brook Turner (interviewed 25/06/2014) to show that not all social enterprises are the same. There are various forms of organisations that are called a social enterprise, but in fact have distinguishing factors between them. 


\begin{tabular}{|l|l|l|l|l|l|l|}
\hline \multirow{4}{*}{ Charity } & Sustainable & Charity & Social & Social & Business & \\
& $\begin{array}{l}\text { Social } \\
\text { Project }\end{array}$ & with & Enterprise & Enterprise & Business & Business \\
& & & & & \\
\hline
\end{tabular}

To go into more depth with these titles, Turner (interviewed 25/06/2014) gave the following definitions. These are not exclusive and comprehensive definitions, but are useful to gain further insight into this continuum. Where the coffee companies, that I did interviews with, placed themselves will be discussed in the next chapter:

-Business with bottom line of profit: This is the entity where making money is the number one priority. In terms of impact on society, proponents of business often endorse trickle-down theory for the impact it will have on society. The more money that is made by business, the more will trickle down to other parts of society, thus benefiting everyone. This though is a bi-product of the main intention of financial profit.

-Business with ethics: the next step on the continuum to a social enterprise, these businesses acknowledge that pure business has not worked for society as a whole. It is part of a system that has benefitted some, but not others. Businesses with ethics consider the supply end of the supply chain, where products are produced. They are businesses that focus on how they get goods and what they pay for them at the wholesale level. This process has to be conducted ethically. Trade Aid, fair trade chocolate and coffee are examples of these. These businesses ensure that the people producing the goods will be paid a fair price that is equitable with the purchase price. After this point of supply the product will be sold to consumers at a profit and everyday people will sell it. No other aspect of the business will change, or be ethical, other than paying a fair price for the product. 
-Social business: This is a business that is not just sourcing the ethical product; they are employing people who otherwise would not get work. Or they are sourcing an ethical product and all the profits after the businesses bills are paid for (the buildings are maintained etc.) are going back to the producers. This could include investment in hospitals, schools, community gardens, among others. In social business there are two parts of the business that are working to a social end. First, an ethical price is paid for wholesale goods which raising the standard of living for the producers in developing countries. Second, the profits from the sale in the West are going back to those same people, or to another group that benefit socially. The other possibility is that individual's who would not otherwise have an opportunity to work in a business such as this, get a chance. This could include here in the West or in a developing country.

-Charity: An entity working for social aims. In this there is no economic engine, and it requires funding entirely from philanthropy, business or government.

-Sustainable social project: This is where money is donated at the start, but once it is set up it is self-sustaining. This is taking philanthropy and using it as seed funding to create a model of practice in business.

-Charity with enterprise: This is where a charity has actual components of what it does that sits closer to social business. These two types of entity are very similar, but charity with enterprise comes first from a charity lens. It is a charity that is running a profitable business.

-Social enterprise: Finally, a social enterprise is an emphasis both of charity and business models. It has ethical practice in staffing, the use of profits, and has investment back into the community as well as back into the business itself. In this entity it can be seen where the goods come from, the business model stacks up, and it is profitable.

\subsubsection{Limitations and cautions with social enterprise}

It is important to note that this discussion does not promote all organisations becoming a social enterprise. As Turner (interviewed 25/06/2014) said you, do not want to create an "organisational Mecca around social enterprise". So not every organisation should work towards becoming an 
social enterprise, rather it is a new category between more established forms of organisation. Social enterprise is a new and exciting model, but it has limitations, as do any other models. It is very important that transparency of motivations occurs with these enterprises. This model has the potential to be co-opted as much as other models, so caution should be taken. There will always be negative side effects of business, so one must take a pragmatic approach to this model. It will not be perfectly ethical, but it is definitely a move in the right direction. There is some work you cannot monetise, so charity work will be needed. It is also important to note that this model is not new but the labelling of organisations as such is. For example, Salvation Army stores sell second-hand goods to people in need for profit, and then reinvest that profit back into charitable initiatives.

\subsection{The coffee Industry as a place for social enterprise}

Coffee is a drink that millions of people enjoy around the world. It is a commodity that is inextricably linked with our everyday lives (Jolliffe, 2010). This place of normality does not portray how it became to be part of the Western middle-class lifestyle. Historically it was and presently still is characterised by inequality and exploitation. Coffee emerged as a significant trade commodity as a part of European colonial expansion (Fridell, 2007). This inextricably links it with the wealth extraction in Latin America, Asia, and Africa, the slave trade and the industrialisation and new levels of consumption that occurred in England, Europe and North America (Fridell, 2007). History has placed the coffee industry firmly in the unequal terms of trade between the North and South (Jaffee, 2007). Jaffee (2007) states:

"The terms of trade between North and South-the low prices paid for agricultural products relative to the cost of imports (on a national level) or the cost of living (on a household level)-have long been unequal, but they have worsened significantly for the global South since the 1970s" (p.11).

It is a volatile industry, and is subject to repetitive cycles of boom and bust caused by discrepancies between supply and demand (Fridell, 2007). This 
makes the incomes of production difficult to rely on, as coffee prices fluctuate from year to year. This industry also reveals global inequality, as there is a 'coffee boom' occurring in consuming countries, but the gains of this are not seen in producing countries (Daviron \& Ponte, 2005). The nature of the coffee industry is "highly exploitative and volatile", particularly for those at the bottom of the hierarchy upon which it is constituted (Fridell, 2007, p.132). Geopolitics often contributes to its volatility, as coffee often comes from countries with political issues. And because coffee is such a major part of their economy, control of it is fiercely fought over.

Macauley (interviewed 11/06/2014) reflected on his experience of the coffee industry, and made it clear that the 'strangling' (in terms of payment to farmers) of the coffee industry is killing it slowly. He stated that, as it is, there is not a stable future for coffee farmers, which would provide them an incentive to continue in the industry. For years coffee farmers have been underpaid, which is now beginning to affect the long-term sustainability of the industry. Due to the poor payment of farmers, the new generations in these families are being encouraged to study or find work elsewhere, as there is no perceived future in coffee. Also, poor payment means there is less incentive to maintain farms, leaving them prone to disease, causing a drop in the quality of the crop.

\subsubsection{Ethical turn in the coffee industry}

Some parts of the global coffee industry have gone through the same ethical turn that other aspects of the economy has, which again provides a space for social enterprise. These parts of the coffee industry recognise their own responsibility for poverty, particularly with regard to coffee farmers. The industry is also beginning to realise that consumers need the ability to check their decisions and the implications of those decisions accordingly. And as we shall see, companies such as the social enterprises I have interviewed, allow individuals to make more educated decisions. According to Lamason (interviewed 18/06/2014), prior to the ethical turn discussed in the previous chapter, many players in the coffee industry did not know about the plight of coffee farmers, due to the separation in the supply chain. But there is now more 
and more information about the lives of farmers, and the work they put into farming coffee. This has led a small portion of the coffee industry to respond in an ethical manner by changing their business practice. Unfortunately, for some companies this can be just a surface level change, the green washing of companies, and does not entail much real change. Raising prices is unpopular in a competitive business market like coffee, so ethical change can be resisted.

One way the coffee industry has worked in a more ethical manner is through supporting coffee co-operatives. Co-operatives worldwide now have over a billion members (Stewart, 2012). They help to support small-scale producers, particularly to make the most of economies of scale (Stewart, 2012). This helps to raise the standard of living and empower the communities that coffee farmers are a part of. Co-operatives also help with social and environmental outcomes, and becoming certified with various trademarks in these areas. Through the support of co-operatives, importing companies make an active choice to work with coffee farmers who are some of the most poor and vulnerable people in society (Chandler, 2013). And ultimately, as Johanson (interviewed 27/06/2014) put it, when it comes to long-term sustainability "our health is dependent on their health, so we [should] make them as healthy as possible in doing the right things". One of the main ways this ethical turn has been outworked is through the fair trade movement.

\subsection{Fair Trade}

Fair trade plays an important role in the discussion of the ethical turn and social enterprise's role in the coffee industry, as it encourages the creation and continuation of "linkages between Southern rural livelihood struggles and morally reflexive consumers" (Goodman, 2004, p. 908). In 2009, there were 250 FLO businesses in Australia and New Zealand making these linkages (Fairtrade AUSNZ, 2010). Overall in the fair trade industry, in 2009 conservative estimates put the number of people benefitting from fair prices, social premiums and advantageous terms of trade in excess of 5 million (Trade Aid, 2009). It defines itself and only has meaning when framed against the dominant order of the capitalist economy (Luetchford, 2008). So it works within this dominant order, 
attempting to alter it rather than replace it. This correlates with social enterprises changes to business and charity, as well as post-developments approach of reframing development. Schmelzer (2010) describes it as 'buycott' - as oppose to a boycott, it urges consumers not to abstain from purchasing ethically questionable goods, but to use their money to bring about ethically preferable goods. Coffee social enterprises require the same from consumers. Fair trade's core values are centred on two components:

"First, fair traders seek to provide immediate, tangible benefits to Southern partners, and, in the medium term, enhance their capabilities to survive and compete in the global capitalist economy. Second, fair traders seek to create an alternative model of international trade, and, in the long term, aspire to be part of a broader political movement that challenges the structural sources of exploitation and inequality, depicted as being either the institutions of neoliberal globalization, or, in more radical circles, the capitalist world system in general" (Fridell, 2007, p. 277).

For many people "fair trade means opposing depersonalised economic relations, objecting to 'middle-men' concerned with only making profits, and decrying a modern economy in which all things take the generic commodity form" (Luetchford, 2008, p.153). Fair trade then represents one solution to these problems:

"[it is] expressed through the idea of drawing producers and consumers, production and consumption, closer to one another in order to realise the quality of objects and the value of labour embedded in goods, as imparted by growers in specific places" (Luetchford, 2008, p.186).

Fair trade certification uses the following criteria to ensure fairly traded goods (Jaffee, 2007, p.2):

- Guaranteed minimum (floor) price to producers; fair wages to labourers; social development premium

- Advance credit or payment to producers

- Democratically run producer co-operatives or workplaces

- Long-term contracts and trading relationships 
- Environmentally sustainable production practices

- Public accountability and financial transparency

- Financial and technical assistance to producers

- Safe, non-exploitative working conditions

Fair trade can also be seen as a social movement, as well as an alternative market, as it tries "to create more direct, socially just, and environmentally responsible trade relations-mainly between disadvantaged farmers in the global South and concerned consumers in the North" (Jaffee, 2007). This places it squarely in the uneven globalisation of the current world order, using the buying power of consumers in rich countries to improve the incomes and working conditions of producers in the global South (Schmelzer, 2010).

There are limitations to fair trade though. Jaffee (2007) believes that the coffee producers participating in the fair-trade market do receive real and significant benefits-social, economic, and environmental; but argues it should also be questioned how much fair trade actually protects farmers from "the harshest impositions of the market" (p.5). It is also embedded in Western notions of the economy and morality, so its universality could be argued against (Luetchford, 2008). It could also be argued that many businesses are exploiting the fair trade movement now that it has become popular

According to the participants in the interviews, who use varying forms of fair trade coffee, supporting fair trade is preferable to traditional forms of trade. It can be limiting though, because they do not capture as much of the market as they could, or have access to as much coffee. It is hard to be an end point for coffee farmers in an environment that is always seeking lower prices of products. So it is difficult for retailers and coffee companies at the consumption end of the chain to continue their ethical practices. Lamason (interviewed $18 / 06 / 2014$ ) argued that in many ways we live in a post-fairtrade world. It has been in the public eye, and its popularity as something new and exciting is beginning to wane. This may be true for progressive cities such as Wellington, Christchurch or Auckland, but is difficult to see this as true elsewhere. It is a difficult position to be in for businesses in these centres, whose bottom lines are still to work ethically. It is difficult to keep reinventing yourself when you have a 
bottom-line to address an issue, namely economic injustice, which is not going away.

\subsection{Influence 'over there'}

"For our trade, for our farmers, I'm very confident that our money does great work in the communities. And I do feel like the coffee I roast, and the coffee we sell, each cup is going towards making a change. And I've seen those faces first-hand. I've seen new hospitals and new roads, and all sorts of things, purely because some of the key aspects that are inside our trade. ... so I definitely agree that it can be used as a tool to make change. It's a lovely idea to think that, through your expenditure and through luxury, you can actually be adding value back" (Macauley, interviewed 11/06/2014).

As stated earlier, social enterprises can be seen as part of a community economy, which is trying to bring back ethics into the market. Gibson-Graham et al. (2013) state that encountering distant others through international trade is an important part of the community economy. In the coffee industry, this works out as consumers encounter small-hold coffee farmers in developing countries. It is important then to recognise the relationship consumers have with coffee farmers, and the potential influence ethical trading can have on the farmers, creating in developmental outcomes. It can be seen as an avenue for outworking post-development practice, and being an avenue to show solidarity with these distant others, As Matthews (2008) encourages, a key influence of a social enterprise model is that, when applied to the global trade that a company may do, it humanises the supply chain. Humanising the supply chain means turning economic interactions into relationships, where care for others involved in the relationship is an important consideration. Development outcomes can be achieved in this process.

Participants in the interviews believed that development outcomes can be achieved through business, but they emphasised the need for a bottom-up or grassroots approach. Development aims should be defined locally and occur organically. This is where supporting local co-operatives would be beneficial, and again where Matthews' (2008) idea of supporting popular initiatives could 
be applied. Participants also emphasised that business can be used for development as long those who are being developed are in charge of it. Macauley (Interviewed 11/06/2014) stated, “I don't think business should be involved in development when it's outside of the peoples' hands that are being developed". If the work of the business is respectful and understands the dynamics and dignity of people, and supports the needs of a community, it can be a powerful support base. It can then become a way of combating the exclusivity of business and the market.

Working with co-operatives appears to be a good model for social enterprise, and achieving development outcomes. And this is not exclusively for the coffee industry, it can and does work with other primary goods. Cooperatives encourage a sense of solidarity between the importing business and what the local producers are trying to do. The business has a hand in assisting the local community in developing themselves as they see fit. This means that it is no longer just that there is trade going on between two parties, it is also about how they relate and support each other. Being financially successful at any cost in the process becomes untenable with this model. Many participants made it clear that they want to ensure that what they are doing is making the lives better for those that are growing the coffee that their business relies on. Social Enterprise then provides a model that can be mutually beneficial for all involved.

One important aspect of coffee social enterprises work is representing the coffee farmers to consumers here in New Zealand. In this way they become a place of advocacy on behalf of the coffee farmers, and a place of learning for consumers. Turner (interviewed 25/06/2014) was of the opinion that social enterprise can become a billboard or marketing campaign to advertise global issues, thus raising awareness:

"And I think the goal is to become conscious. Ignorance is the sin I think, and to be ignorant of the world that we live in; in the fact that we've got depleting resources, that we're over using the resources of the planet because of human greed, and because of human inequality" (Turner, interviewed 25/06/2014). 
Purchasing coffee from a café is one of the main ways an individual in New Zealand could learn about these farmers, without proactively doing their own research. And from Lamason's (interviewed 18/06/2014) perspective, the farmers he interacted with were in favour of being represented by these coffee companies, as they felt in solidarity with one another. In fact they encouraged them to tell their story. He stated that farmers gave the view:

"We are farmers in a co-operative and we are in solidarity with one another. You coming here and buying from us puts you in solidarity with us. Anything you can do to increase the work that we do here go and do it" (Lamason, interviewed 18/06/2014).

So there is not a concern, at least in the coffee companies I interviewed, of having the farmers names or stories co-opted. If anything, the concern is that their story is being wasted, as consumers do not always pay attention to it. To know this for sure would require further research into consumer reactions to these companies marketing approaches.

\subsection{Influence here}

This is a point I had not anticipated in the lead up to my research, but which has now become a crucial point. It became clear that a business such as a coffee company working ethically in a developing country is inseparable from them working ethically here as well. Because how much interaction these companies have with the public, it is almost expected that they work ethically here too. The same principles of fairness apply when doing work here or abroad. These businesses have the potential to address issues of inequality and poverty here in New Zealand, as much as they do in a developing country. In doing so they make a contribution socially to the community they are a part of, not just economic contribution. This does not negate a businesses economic contribution, as this is important for the development of a community, but does bring new emphasis to their social contribution.

Many of the coffee companies I interviewed had become a big part of the social fabric of a community here in New Zealand. This also means that they produce social capital, and contribute in that way. Now if these companies were 
to leave there would be a loss, or tear, in the social fabric. These companies have also become a hub for the community, where people from many different backgrounds can come together and engage each other, and engage in issues around coffee. This transcends their use from just a place to get coffee. Johanson (interviewed 27/06/2014) stated that cross-cultural interactions are a large part of their work, and the principles that are applied in those interactions can also be applied globally. For example, with money management, he mentioned a case of a Pacific Island youth working at Roskill Coffee Project, where all their earnings went straight to the family. This is just one example of encountering different lifestyles here in New Zealand through the café. Through encouraging these cross-cultural interactions there is more potential to encounter others with different lifestyles.

Coffee social enterprises can also help bring about social change in the community. Many of the cafés are deliberately set up in poor socio-economic areas, in the hope of positively influencing these places. Lamason (interviewed 18/06/2014) agreed:

"Cafés like those, and Peoples, make Newtown a happier, safer place because you attract people that care and socially interact a lot and they float around those places. They don't just go there and go out, they float around them, they meet and they go back. And [Peoples Coffee] Constable Streets very much like that."

Additionally, businesses that adopt a social enterprise model can bring empowerment and dignity to those who otherwise may find it difficult to find employment. Combating exclusion in this way is an important part of social enterprise (OECD, 2000). One criticism that could be made of social enterprises is that they are only popular among the wealthy middle-class, and that there is not much buy-in by other demographics. Johanson (interviewed 27/06/2014) noted that when given the opportunity to engage in issues of global inequality, the local employees and patrons from Mt Roskill were as concerned about these issues as anyone else. 


\subsection{Summary}

This chapter has provided a brief summary of the coffee industry, showing its history and contribution to the inequality and exploitation that is apparent in the industry. As part of the ethical turn in the economy, fair trade and social enterprise have attempted to correct some of these inequalities. Social enterprise holds a unique position in that it marries the entrepreneurial aspects business with the social aspects of charity. Social enterprises in the coffee industry can have multiple levels of impact. Social enterprise can encourage the humanising of the supply chain on a global scale, and in doing so enable consumers to encounter 'distant others' in their purchasing. Locally, social enterprises can address issues of inequality and poverty here in New Zealand, as much as they do in a developing country. In doing so they make a contribution socially to the community they are a part of, not just economically. This provides a theoretical framework for the discussion of the cafés that were interviewed, each of which will be presented as case studies in the next chapter. 


\section{Chapter Six}

\section{Case Studies}

\subsection{Introduction}

This chapter will look at case studies of all the coffee companies that I interviewed. For the most part each section is a summary of what the participants reported about themselves. It will reflect their opinions on the market, social enterprise and their model of business, and the impact they have locally and globally. Their history, location, coffee procurement, organisational make-up (particularly in relation to the social enterprise continuum shown in the previous chapter), marketing approach, and use of profits will be described. In doing so, it will compare and contrast the different coffee companies to show their different make-up. As will become clear, each coffee company takes a different approach in outworking their values and what they deem important. Each section will discuss where the coffee companies placed themselves on the social enterprise continuum. It should be noted that the definitions given for each title in the previous chapter were not available when asking the participants, as Turner (interviewed 27/06/2014) only gave these at the end of the interview process.

\subsection{Addington Coffee Co-op}

"So I think we're a modified capitalistic business, and I suppose you could say we have charitable overtones. But philosophically we don't see ourselves as charitable, we see ourselves as looking at actually what's happening and saying that's not actually our money. Who said that we should be able to buy coffee for bare minimum price on the New York stock exchange and that's actually what it's worth, does the free market actually work? So we're only charitable cause we're going against that" (Palmer, interviewed 03/06/2014). 
The interview for Addington Co-op was conducted with Adrian Palmer on June $3^{\text {rd }}, 2014$.

\subsubsection{History}

Plate 1: Addington Co-op logo (2014)

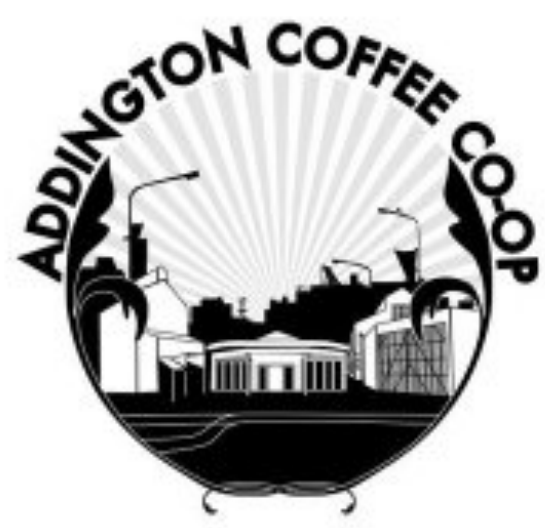

Addington was started by a co-operative, a group of local people that wanted to run a business that was people focused, creating a place of belonging and welcome. Their concern was about the wellbeing and welfare of people throughout the supply chain, as well as in their local community. For the co-operative, coffee was just an avenue to outwork these ethics, and as the ethics of fair trade and coffee were well established it helped their cause. They were not necessarily passionate about the coffee industry.

Through the interview, Palmer (interviewed 03/06/2014) showed a critical view of capitalism and its theories, such as free trade and the effect trickle down has for the poor. As shown in the introductory quote, he questioned the traditional make up of business, particularly what is done with profits. Palmer questioned that if producers cannot afford to live, how can consumers use the products they produce guilt free. As a response to this, the company aims to rework capitalism in some small part from within, to give consumers the opportunity to engage with a café they may deem more ethical. This would be done instead of, as Palmer (interviewed 03/06/2014) put it, "running away from" capitalism. This demonstrates a clear social ethic that Palmer and the company hold. 


\subsubsection{Location}

\section{Plate 2: Addington Co-op location (2014)}

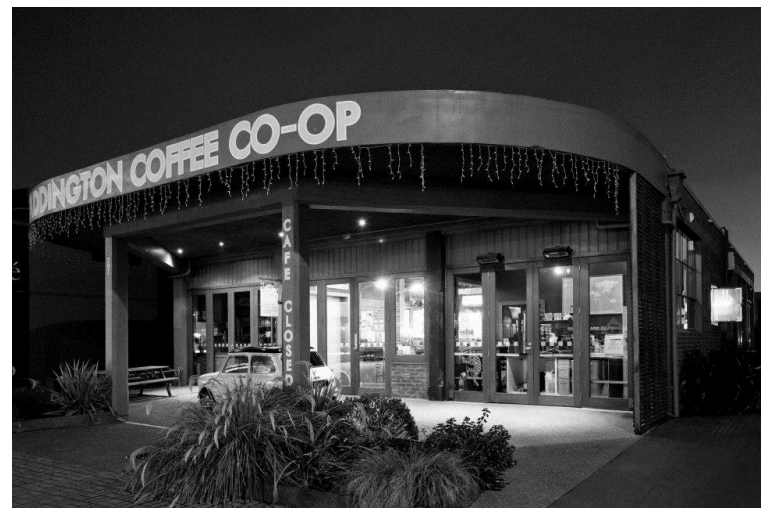

As the name shows, this coffee company is located in Addington, Christchurch. Addington as an area is a mix of residential and light industry, and is described as a low socio-economic area (Christchurch City Christchurch City Council). Damage from the earthquake in 2011 was minimal, and since then this area is in fact experiencing a business boom (Christchurch City Council, 2013). This is true from my experience, as the café was bustling and busy all the time I was there, whereas further in to town became very quiet.

\subsubsection{Supply model for their coffee}

Addington purchases its coffee directly from Trade Aid, and then roast it themselves in the café. Trade Aid is a World Fair Trade Organsation (WFTO) certified coffee. Again, for Addington, coffee is an avenue for them to make social change. Palmer (interviewed 03/06/2014) stated that they would work with something else if it worked for what they were trying to achieve. But Addington as a company sees that coffee is a highly traded commodity, and so involves a lot of people, and therefore it can have a significant impact. Palmer (interviewed 03/06/2014) stated that small-holder farmers struggle to obtain economies of scale, so supporting these farmers, investing in the future of coffee and the health of the plants, and in turn the industry, is important.

Palmer (interviewed 03/06/2014) noted that the coffee industry in New Zealand is small, but competitive, and through this competition, quality is increased. However, people are still willing to share ideas and help each other, which shows a level of camaraderie in the industry. Often, Addington chooses not to follow trends in the coffee industry (for instance buying new machines) in the hope that it represents what people that patronise their café want, which 
then frees up more money to go back to the coffee farmers and their communities.

Palmer (interviewed 03/06/2014) also made an interesting point that he is not so concerned about the title of how your trading, or the particular model. As long as the principles are good, and they are looking after the vulnerable parties in the trade relationship, then the model is not of as much importance. It is true that companies should have good principles, but when there are different trading models it becomes difficult to trust these models, when there is no standardising that happens, such as with fair trade certification.

\section{$\underline{6.2 .4 \text { Organisational structure }}$}

"I think we are a business that takes in the needs of employees, customers and suppliers/producers. We take into account those needs more so than those shareholders that put up the capital. Whereas most business's primary goal is to deliver profits to shareholders" (Palmer, interviewed 03/06/2014).

Addington as a business does not want to be seen as charitable, or to rely on others charity for them to run. Instead, they want the business's way of operating to be financially viable and a sustainable way to do business. This is an important point as it makes the company reliable for the groups they work with. Palmer (interviewed 03/06/2014) stated that in their work they aim to redress trade imbalances and encourage long-term sustainability of the coffee industry, which benefits consumers and producers. Critical to this is being an organisation that is for people before profit. This motto of Addington includes local people as well as coffee farmers. Addington as a company wants to be good employers, giving people an opportunity to buy in to their vision. And as shown earlier they support small-holder farmers through Trade Aid, which then provides the farmers the ability to support themselves. They do this instead of "leaving them for the market to decide" what happens to the farmers (Palmer, interviewed 03/06/2014). 


\subsubsection{Marketing approach}

In terms of marketing, this café is definitely people and community focussed. There is a relatively equal focus on the local and global, with maybe a slightly stronger local focus. There is a store within the café that sells Freeset (a clothing company based in Kolkata, India) goods, as well as other craft-ware from developing countries. There are posters and pictures up around the café as well, which show what they are doing in the local community, such as farming to grow their own produce. Palmer (interviewed 03/06/2014) stated that their marketing of the social aspects of the company are not extremely overt, but it can be found through the website and art displays in the café. He saw this as an area for improvement.

\section{$\underline{\text { 6.2.6 Use of profits }}$}

Palmer (interviewed 03/06/2014) made it clear that the profit they made in the café was not perceived as their profit, that they wanted to put the relationships they have with people before making a profit. This entailed the redistribution of their profits, through Trade Aid, to the producers of the coffee. He stated $30 \%$ is reinvested into the company; the rest is re-distributed either to their local projects or back to the coffee farmers through Trade Aid.

\subsection{Crave Café}

"So we built the café as a primary response to engage the community, and engage the neighbourhood. Not for them to meet us, as for everyone to meet everyone... what we want is to help people to feel like they belong, like they're local, like they have some place here, and that this is something worth looking after" (Cottle, interviewed 26/06/2014).

The information in this section is from an interview with Nigel Cottle, conducted June 16, 2014. 


\subsubsection{History}

\section{Plate 3: Crave Cafe logo (2014)}

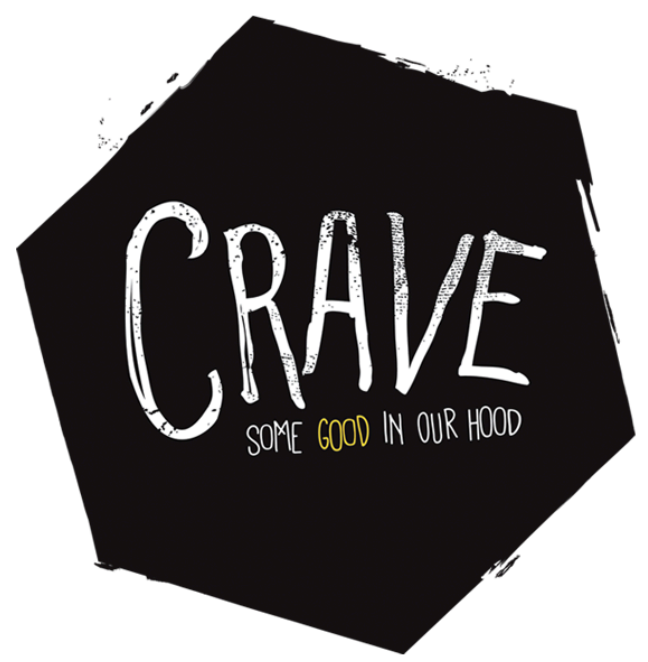

Crave was started by a group of eight Christians, who had started a collective together (this now involves fifteen people). As Christians they believed their community should become a better place from them being there, so decided to outwork this philosophy through a café. The collective continues to hold the café and those who work there to the values that undergird the work when it first

began.

\section{$\underline{6.3 .2 \text { Location }}$}

\section{Plate 4: Crave Cafe location (2014)}

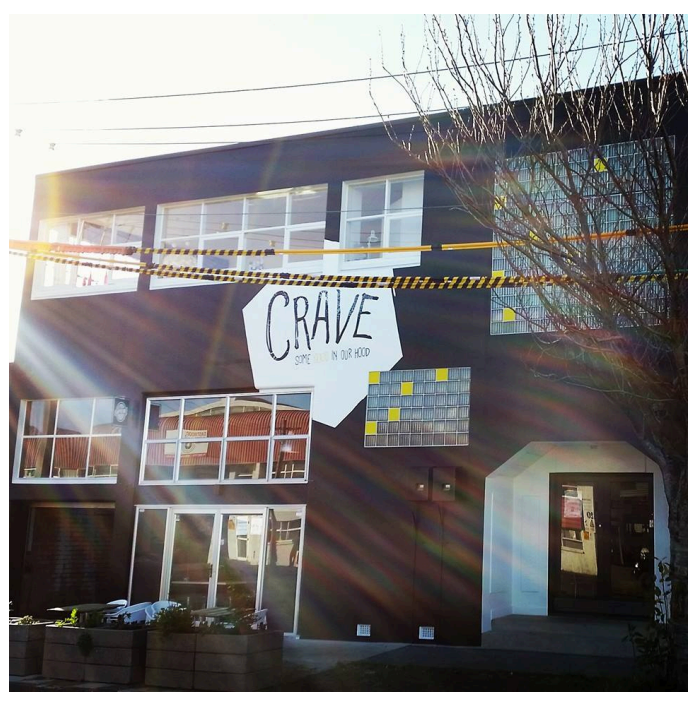

Crave café is based in Kingsland, Auckland, an area that is a mix of light industry and residential (Auckland City Council, 2013). Cottle (interviewed 26/06/2014) described it as a transient community, which had a high proportion of youth. Overall it has a mix of demographics in terms of wealth and ethnicity (Cottle, interviewed 26/06/2014). He stated that it is not a good spot for a café; you would not know about the café unless you lived or worked near by, or cared about the cause. In terms of impact, Cottle (interviewed 26/06/2014) said it was difficult to quantify the change that has happened in the community, but there has been a growing amount of 
community engagement from when they first began, such as more people coming to the street parties they put on. Five more cafés have opened in the area since Crave first began, which may signify a changed perception about the area as a possible successful café location.

\subsubsection{Supply model for their coffee}

Crave get their coffee from Coffee Supreme, a Wellington based roastery. The company had personal relationships with people in Supreme so chose to go with that over other options. Cottle (interviewed 26/06/2014) trusted the Supreme model for producing coffee, and that Supreme are passionate about it and moving the coffee industry forward in New Zealand, making it high quality and internationally competitive. Cottle (interviewed 26/06/2014) admitted they are more aligned to Peoples in terms of values, so will use them at events, but prefer Supreme more for the quality. He made it clear Crave strives to make their coffee the best in Auckland. Unlike Addington Co-op, coffee is not just a vehicle for outworking their values - they want to be proud of it and know it is high quality.

According to Cottle (interviewed 26/06/2014), Supreme opted out of any fair trade certification because the best quality coffee is not available through it. He argued though that Supreme still trade fairly, and pay the farmers more than they would usually get. Further research would be required to verify this. Fair trade is still important for Cottle (interviewed 26/06/2015), especially for big companies, as he does not trust them when they say that they are working ethically. But New Zealand companies who are working directly with farmers are comparatively small, and therefore can be trusted to work ethically. He states:

"I'm simultaneously a big believer in fair trade but also within our NZ coffee scene understand that we're small enough that you can't get away with bad practice. And there's enough people doing it really well, that's the norm and that's the standard. And so I really like that about what we do here" (Cottle, interviewed 26/06/2014). 


\section{$\underline{\text { 6.3.4 Organisational structure }}$}

"For us we want to prove that we can do this thing well, we can have excellent coffee, excellent food, and have a social heartbeat, and be sustainable" (Cottle, interviewed 26/06/2014).

Cottle (interviewed 26/06/2014) described Crave as hyper local, in terms of its core focus. As shown in the quotes earlier, the café seeks to create a sense of belonging and engagement for the local people of Kingsland. They believe that having cafés in the community gives more opportunities for people to engage with each other than they would otherwise. Growth and expansion is not a key part of the business plan, although influencing other businesses through the power of relationship is, as it then affects the community more. They often have street parties, have concerts in the café, and show rugby games. In the past people have been employed that would find it hard to get work otherwise (addicts, people with criminal records). They aim to give them experience and skills and mentoring in that difficult first stage of getting in, or back in to, the workforce.

Interestingly, Cottle (interviewed 26/06/2014) argued that they are for social advancement, rather than social justice. This means they work for or towards something, rather than fighting against social inequality. This reveals a constructive approach to social ills. As individuals they get involved in social justice issues, but not the café. The café has some international focus, as people from the Kingsland community have gone overseas with members of the collective to visit development programs they are involved with (such as Loyal Workshop who work with Freeset).

In terms of the social enterprise continuum, Cottle (interviewed $26 / 06 / 2014$ ) placed them squarely in the middle as a social enterprise. This is because Crave is a business working for their mission without support from philanthropy or government. He believes that often organisations have good 'hearts' or values but these values are poorly executed. This is when an adopting a business model can improve efficiency. Everyone is employed that works in the café, so they do not rely on volunteers. 


\subsubsection{Marketing approach}

Crave is currently going through a rebrand, which will tell the story of the café. This storytelling has been especially developed and improved digitally, via the website. Again, the design of the café encourages engagement (communal tables etc.), with a high quality product and a friendly environment as the means to draw people in. And Cottle (interviewed 26/06/2014) emphasised that this engagement does not discriminate between consumers with different values:

"People come in here and they are consumers, but we want to provide them with a good thing to consume: so quality coffee, quality food that's tasty, flavoursome. And for some people that's all it is, and there's a journey that people go on. And we find that some people will hang out with us just for those things, and over time the relationship develops, and the engagement happens. But for some people, it doesn't, they are just purely here to consume good tasty coffee for a season, and then they... And so we don't set ourselves up to primarily cater to those people that just want to take, but if you want to, like most people... So if you have a social conscience, and you come here, you'll feel a lot better about being here than another place. But if you have no social conscience and you come here, you'll just enjoy the coffee and the food and you'll be fine. Cause we won't guilt people into something else, we'll hopefully inspire them" (Cottle, interviewed 26/06/2014).

\section{$\underline{6.3 .6 \text { Use of profits }}$}

Profit is not the main driver for Crave, rather it is what keeps the vision of the organisation sustainable. In the process of making a profit, they want to do good, which helps people trust the company. Of the profit, $20 \%$ goes to global projects (Mad for Change, working with Freeset), and 80\% to local initiatives (street parties, sponsoring people etc.). Cottle (interviewed 26/06/2014) stated that not enough profit is being generated to say that redistribution of wealth is a primary motive. Because of this they are helping the community socially, more than they are financially. 


\section{$\underline{6.4 \text { Kokako Café }}$}

"My personal belief is that just like the rest of the food industry, consumers want to know where their food and their beverages come from. Not all of them do, a lot of people just wanna come and get their flatwhite everyday and they don't really care, but an increasing amount of consumers care about where their food and beverages are sourced from. They care about whether the growers received a fair price for their coffee, they care about whether it's organic, whether its got pesticides on it, or how it was grown. So I believe that it's an important part of what we do" (Mike Murphy, interviewed 27/06/2014).

The information for this section was gathered through an interview with Mike Murphy, conducted 27/06/2014.

\section{$\underline{6.4 .1 \text { History }}$}

\section{Plate 5: Kokako Cafe logo (2014)}

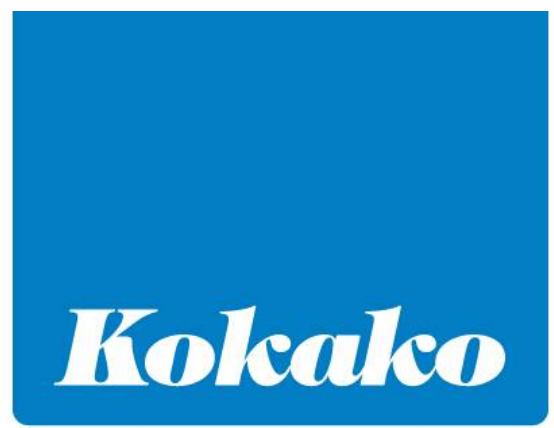

Kokako was started in 2001 as New Zealand's first organic roasting business, and was named after the Kokako bird. Murphy (interviewed 27/06/2014) purchased the company from the original owners in 2007. Murphy did Human Geography so also had an interest in sustainability, ethical procurement and transparency in the supply chain. 


\section{$\underline{6.4 .2 \text { Location }}$}

\section{Plate 6: Kokako Cafe location (2014)}

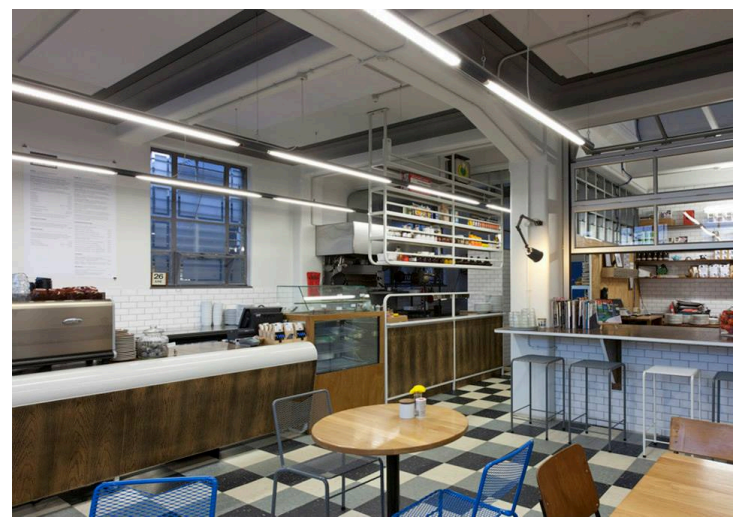

Kokako is based in Grey Lynn, Auckland. Murphy (interviewed 27/06/2014) stated that Grey Lynn is going through a process of gentrification so is quite a wealthy suburb. Kokako like to see themselves as a hub in this community.

\subsubsection{Supply model for their coffee}

Kokako is Fairtrade (FLO) certified and is a part of Biogro (environmental certification) as well. The transparency these require, and the third party verification they offer were reasons for joining. Murphy (interviewed $27 / 06 / 2014$ ) did not have a problem with paying the extra premium for coffee. He stated it can be difficult, as a small company, to pay the $2 \%$ licensing fee on wholesale coffee and the more money you make as you grow the more you have to pay. But Murphy (interviewed 27/06/2014) believed it necessary to pay for the organisational costs of FLO. And again the third party verification provided was worth the fee.

Murphy (interviewed 27/06/2014) stated he was concerned with how the fairtrade, organic and quality premium were used. He went on a trip to Papua New Guinea recently, to see how their co-operatives are operating and found everything (such as book keeping, water reticulation, infrastructure, schools) was working well.

\subsubsection{Organisational structure}

For Kokako, a quality product is their number one priority. They try to attain this whilst still being sustainable and conducting ethical procurement. Murphy $(27 / 06 / 2014)$ stated that transparency right through the supply chain is critical 
for this, as well as continuing to consider the coffee farmers and the work they do, through all the operations of the café.

The company also places great value on environmental considerations. Murphy (interviewed 27/06/2014) states:

\footnotetext{
"What a lot of people don't understand is that it's not just about the Fairtrade premium, it's about environmental sustainability as well as quality. So they all go hand-in-hand. So when a co-op is certified as Fairtrade, its not just certified as Fairtrade from a financial perspective, it's certified based on how they grow the coffee, how they harvest the coffee, what they do with compostables, how they can regenerate the land through that and then their environmental footprint as well."
}

This environmental focus is also shown through sourcing local organic goods, and supporting initiatives for the rehabilitation of the Kokako bird, such as the Rotoihu Ecological Trust and Ark in the Park. Murphy (interviewed 27/06/2014) placed Kokako on the social enterprise continuum as being between business with ethics and social business. They do have ethical considerations they adhere to, but are there to make a profit as well. Murphy (interviewed 27/06/2014) said if the company were truly capitalist, it would not be paying the premiums the Fair trade certification requires. Kokako has shareholders and 22 staff, so the company is required to be financially sustainable.

\subsubsection{Marketing approach}

Kokako places much emphasis on quality of product, and the design of the café. The design aesthetic of the company is consistent and well thought out. There is documentation available, both on the company and also on Fairtrade and Biogro, which helps communicate the values of the company. This information is available through pamphlets and on the website. The name of the company alludes to the environmental emphasis it has.

Supporting locally sourced, ethically traded goods is part of new, thriving trend (Moore Wilsons, Enviro Fresh, Commonsense Organics) that represents a shift in consumer preferences. Kokako definitely tries to appeal to this. Murphy 
(interview 27/06/2014) was aware of not relentlessly marketing that they are Fairtrade certified. He believes this can do more damage than good, that it can put people off and make them feel stupid for not being more aware of global issues. Murphy (interviewed 27/06/2014) would rather people be surprised and delighted that the coffee they're consuming is ethical. It is also important to strike a balance on how much information you provide, as you do not want to overload people.

\subsubsection{Use of profits}

The company has a traditional business model when it comes to profits, but does often donate coffee often to community initiatives.

\subsection{Peoples Coffee}

"For our trade, for our farmers, I'm very confident that our money does great work in the communities. And I do feel like the coffee I roast, and the coffee we sell, each cup is going towards making a change. And I've seen those faces first-hand. I've seen new hospitals and new roads, and all sorts of things, purely because some of the key aspects that are inside our trade. The social premium usage... so I definitely agree that it can be used as a tool to make change. It's a lovely idea to think that, through your expenditure and through luxury, you can actually be adding value back" (Macauley, interviewed 11/06/2014).

"If you have a business, which has a respectful and really understands the dynamics of dignity for people, then I think if that business starts to focus its resources and its attention and its energies on some needs in a community, it can be a really collaborative and powerful support base." (Lamason, interviewed $27 / 06 / 2014)$.

The information for this section is from both Matt Lamason (interviewed 18/06/2014) and Rene Macauley (interviewed 11/06/2014). 


\section{$\underline{6.5 .1 \text { History }}$}

Plate 7: Peoples Coffee logo (2014)

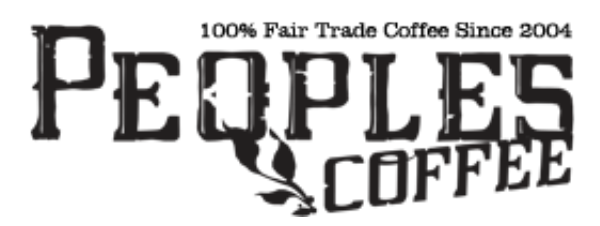

Matt Lamason started Peoples as a fair trade roastery in 2004. In starting this company, he aimed to combine his passion for coffee with desire to apply the sense of justice that came from his Christian worldview. Lamason (interviewed 18/06/2014) said he "tried to cross all these worlds of mainstream consumer wants and needs, biblical justice ideals, and my own enjoyment of coffee and the process of roasting and making coffee". Meeting the co-operatives and the coffee farmers, he became convinced that working for these people was a worthwhile cause to give his life to. He had also done a development paper with Reggie Mascaranas at Victoria University, and been a part of Urban Vision (a Christian community with a strong focus on social justice), which also influenced his thinking. Lamason (interviewed 18/06/2014) found it difficult starting a company in the coffee industry whose premise was ethical, as it was in the early stages of Fair trade coffee becoming established in Wellington. Lamason (interviewed 18/06/2014) often talked at schools and youth groups, doing slideshows to try and get people aware of where coffee comes from.

Macauley (interviewed 11/06/2014) joined the company early on. He had no experience in the coffee industry, but was an acquaintance of Lamason, and was interested in social justice. He had spent some time in India so had experience with developing countries Both participants were critical of pure capitalism and a free market economy. 


\section{$\underline{6.5 .2 \text { Location }}$}

\section{Plate 8: Peoples Coffee, Constable Street location (2014)}

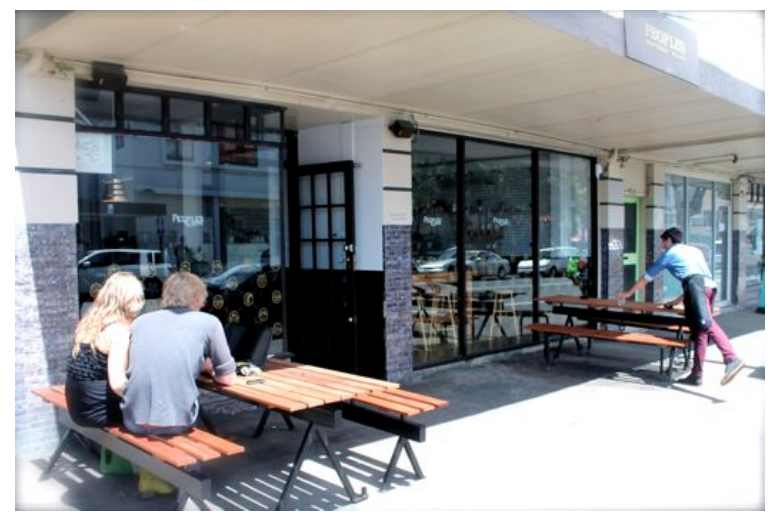

Peoples coffee is located in Newtown, Wellington. They strive to be a hub that is a core part of the social fabric in the community. Lamason (18/06/2014) believes that Newtown is a better place because of Peoples, as it has

contributed much to the community.

\subsubsection{Supply model for their coffee}

Peoples is a part of the World Fair Trade Organisation (WFTO). Their coffee is imported through Trade Aid, and then Peoples roast it themselves. Lamason (interviewed 18/06/2014) stated that Trade Aid have a good international reputation as brokers, and have been buying from the same farmers and investing in them long term. He stated it was difficult to find fair trade certified coffee (there was some organic coffee) when they first started in 2004, as there were only three or four origins to choose from (Sumatran, Mexican, Nicaraguan). Macauley (interviewed 11/06/2014) admitted that buying fair trade coffee is limiting because there is still only a small proportion of all coffee production that is fair trade certified. However, having fair trade and organic certification is important for Peoples, to ensure farmers are using the correct pesticides and herbicides, as there is a long history of sick families and animals, and that they have some financial stability. It is particularly important to show that Peoples are working for the good of the farmers they are connected with. Macauley (interviewed 11/06/2014) did give a warning with working ethically:

"It's powerful, but it's also very easily manipulated and green washed. Business or religion for that matter-when it's tied up with ethics, it's hard to trust people. So there's aspects like third party involved in verifying, which give us as much confidence as you can have around some of those issues" (interviewed 11/06/2014). 
So again transparency is a key aspect of what makes fairtrade so valuable.

Peoples have a significant interaction and relationship with the individual farmers and co-operatives, and consistently go over for visits. Macauley (interviewed 11/06/2014) stated that doing this is very important for Peoples, to know what is happening for them and to stay connected. Their main aim as an organisation is to pay farmers more than they would normally get. The benefits that come from this for the farmers are the social ventures, supported by earmarked money for community projects. The farmers themselves choose the ventures, as Peoples tries to trade with the farmers as equal partners. This relationship gives coffee farmers access to international markets, machinery and infrastructure.

During the interview, Macauley (interviewed 11/06/2014) went into great depth about the farmers, their co-operative structures, the various problems they were facing (such as ageing farmers, or the rust disease on the plants), indigenous traditions and cultures, Trade Aid's work with the farmers, the role of local government in the process, and issues of geopolitics and civil unrest (like in Colombia). This clearly showed how much of a priority the farmers are to them.

\section{$\underline{\text { 6.5.4 Organisational structure }}$}

As stated, Peoples have a strong emphasis on working for the coffee farmers. They have a long-term relationship with the co-operatives, and have mostly worked with the same co-operatives since Peoples began ten years ago (Macauley interviewed 11/06/2014). Peoples' bottom line is addressing injustice for the marginalised. Lamason (interviewed 18/06/2014) went as far as saying that if they could not work with poor farmers the company would not continue. He believed that, on the social enterprise continuum, they started as charity with enterprise because they emphasised the cause over making money, but would say they are a social business now. Macauley (interviewed $11 / 06 / 2014$ ) said that they wanted the social change outcomes of a charity for the farmers, but to do it in the business world. Macauley (interviewed 11/06/2014) continued: 
"We wanted to say to the business world, and especially the coffee world, directly cause of its history, that we can be a profitable business that buys quality beans and pays farmers well, and is involved in making the world better."

Peoples then want to contribute to the community of the business world, but they also benefit from the business world as it keeps them "on their toes" (Lamason, interviewed 18/06/2014). This also reveals that challenging the status quo is a part of their make-up.

Both participants used the phrase 'People for change' as what they want to be themselves, as well as encouraging those who patronise Peoples to do the same. This put an emphasis on individual agency, as they realise that people in New Zealand are indirectly responsible for inequality in the world (Macauley, interviewed 11/06/2014). Lamason (interviewed 18/06/2014) stated that how we relate to people through the market is very important, so consuming ethically is important (though just one part of living an ethical lifestyle). And Macauley (11/06/2014) saw how development could be done through Peoples and their work, but emphasised that it needed to be controlled by the farmers and their communities.

\subsubsection{Marketing approach}

At Peoples there is strong representation of the coffee farmers and that they are working for a social cause, which isevident throughout Peoples advertisement and marketing. Obviously the name 'Peoples Coffee' alludes to this, but also the images they use on packaging and in stores, and the names of some of the blends being after farmers they work with. An example of this is their main espresso blend is named Don Wilfredo, after a Nicaraguan farmer they work with. Through this representation they are trying to give dignity and connection to the product and the farmers. In regards to representing the farmers to consumers, Lamason (18/06/2014) said:

"In travels we did and the talking with co-ops when we brought this up, never did we hear people being concerned. Pretty much always the comments were please tell our story, please tell people what life is like and buy more Fairtrade coffee. They didn't have that very 
western individualist mindset that my identity is... how dare you trade my identity to be bought and sold for the highest prices. There's a lot more sense of 'we are farmers in a co-operative and we are in solidarity with one another. You coming here and buying from us puts you in solidarity with us. Anything you can do to increase the work that we do here go and do it'."

So there was an overall sense of camaraderie between the co-operatives and Peoples. There are also stories about the farmers on the website.

Lamason (18/06/2014) had to work hard to craft the 'story' of Peoples, so people buy in to the brand and are not put off by the issues. Because of this, Macauley (11/06/2014) has found that representing the farmers is challenging. People want to come to a café and have a carefree experience, so do not want to be bombarded by global issues. To try and simplify the issues to fit in to a two minute transaction at the counter does not do it justice. Lamason (interviewed $18 / 06 / 2014$ ) stated that it is also difficult to bring the issue home because of the distance involved. So Peoples have tried to focus on communities, individuals and good experiences they have had, to overcome these challenges.

As shown with Kokako, Macauley (interviewed 11/06/2014) said people care about where things come from now, a change in the last 10 years. Consumers are now realising that there are choices that mean you do not have to contribute as to inequality or unethical practice in the market. Peoples attempts to show consumers that you can make change by changing your choice. They have also invited some customers over to the coffee's origin, as a means of influencing their journey and experience, to show them other realities in the world. In many ways this is what these cafés are trying to do overall, to help people engage with different experiences, lifestyles and worlds.

Peoples does not just market coffee to consumers, but also needs to try and convince business owners to buy in to their brand and product. Lamason (interviewed 18/06/2014) said that this is their main market. He said other cafés do have to pay more to use this coffee, but if the brand is strong enough, and the coffee is high enough quality, that will not be a problem. And once the coffee is in the café it can reach the consumer, which enables more people to engage with the values of Peoples. At earlier stages of the business, Lamason 
(18/06/2014) was more wary of working with people who did not believe in the vision of Peoples, as it might dilute what they were doing. But he is now more willing to work with people with different values than he did in the past, and sees it as an opportunity to share Peoples' values. This is positive because it means people that do not already hold similar values to Peoples are engaging with it, and may have their values changed.

\subsubsection{Use of profits}

Lamason (18/06/2014) made it clear that making money is not the top priority for Peoples Coffee. He stated, “you've got to eat to live, but that's not why you live" (Lamason, interviewed 18/06/2014). So profit is a means reaching the end of caring for the coffee farmers, as oppose to being the ultimate goal. Peoples has only recently become profitable, as they have been reinvesting in the company and servicing debt up until now. They are now beginning to reinvest profits, such as in a project at Arohata Womens prison, which will be a three to four year commitment. Lamason (18/06/2014) said this will not make them money and it is not core business, but it is a way Peoples can affect social change. This then becomes an interesting connection between two parts of society (coffee company and prison) that would not usually interact.

\subsection{Roskill Coffee Project}

"You'd expect, even now but over time, that there'll be a revitalisation of that community through them just being there, not to mention the other things that they might get involved with doing" (Lamason, interviewed 18/06/2014).

"We were part of an intentional community in Mt Roskill. So we were trying to work out how can we as very privileged people just do life in a way that's genuine, but can also positively influence our neighbours" (Johanson, interviewed 27/06/2014).

The information in this section is based on an interview with Rowan Johanson (interviewed 27/06/2014). Unfortunately Roskill Coffee Project has closed 
down since this interview, for reasons of poor facilities, such as the kitchen being too small, and the poor location off the road (Cawley, 2014).

\subsubsection{History}

\section{Plate 9: Roskill Coffee Project logo (2014)}

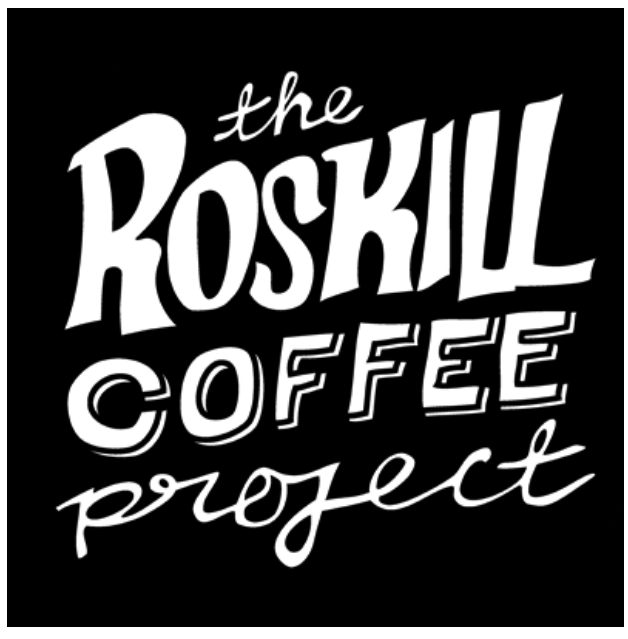

Roskill is the newest company of any that was interviewed. It started with three individuals (including Johanson) who were concerned with outworking fair trade ethics in New Zealand. This encompassed fair trade coffee, sugar, flour, cocoa and other items. They wanted, as privileged people, to live in Mt Roskill and have a positive influence on the community. They were already part of a Christian community in Mt Roskill and were looking to further outwork missional living in the suburb.

\subsubsection{Location}

\section{Plate 10: Roskill Coffee Project location (2014)}

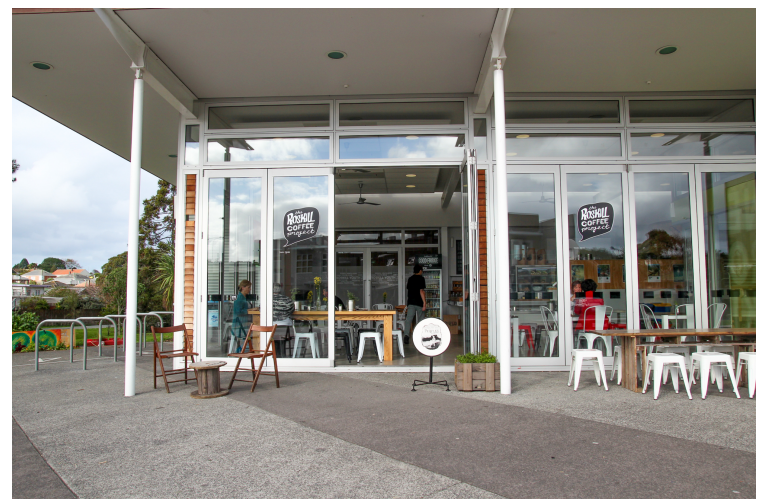

As the name implies, this café is based in Mt Roskill, Auckland. The café is working out of a community centre, a youth space built in 2011 . Mt Roskill as a whole is an ethnically diverse suburb, and there are significant levels of poverty

there (Cumming, 2014). 


\subsubsection{Supply model for their coffee}

Roskill sources roasted coffee from Peoples Coffee, who get their beans through Trade Aid. Johanson (interviewed 27/06/2014) trusts Peoples and Trade Aid that their practices are ethical. Roskill has a strong focus on fairtrade so Peoples fits with that. They appreciate that Peoples actively seeks to work with the vulnerable coffee farmers (Johanson 27/06/2014). He believes that "our health is dependent on their health, so we [should try to] make them as healthy as possible in doing the right things" (Johanson, interviewed 27/06/2014). They also see Peoples as point of difference between them and other cafés, and that Peoples do a good combination of quality and ethics.

\subsubsection{Organisational structure}

When asked to place Roskill on the social enterprise continuum, Johanson (interviewed 27/06/2014) described it as a social business, as they want to be financially sustainable, but are also giving money away, which obviously is charitable. Roskill was crowd funded on the basis that they would be not-forprofit, and use any profit they do make to be an alternative funding source for people who will work for the community. They were also funded to focus on local youth development, not so much about overseas development. But in the use of fairtrade they want to encourage responsible trading (Johanson 27/06/2014). Johanson (interviewed 27/06/2014) stated that Roskill tries to be fair to all peoples, those who are at the production end of the supply chain, and people here in New Zealand.

Roskill has a strong focus on the community, and making change locally. There is not so much focus on global issues, but the see these as inseparable (Johanson, interviewed 27/06/2014). As said earlier they moved into Mt Roskill to engage more in the community and become more aware of the deeper issues that are faced there. They have hired several local people in the café who have left school and would have struggled to find work otherwise. Johanson (interviewed 27/06/2014) stated that cross-cultural interactions were an important part of their work, particularly between pakeha and Maori and Pacific Islanders. He stated: 
"I've been lucky in some ways to grow up in a society that's the same culture as me. My family culture matches my school culture, which matches the church culture, workplace culture. It's so easy for me to move between spaces. And so I can... absorb value really easily. But I think part of it is that that comes with a responsibility to actually then give others that value back that I've managed to soak up, and not say it's my right I earned all this value. The more that we got to know people who are marginalised or who have really difficult lives, we realised its not about I put this hard work in and I got my stuff, and they didn't put hard work in. They flippin tried hard" (Johanson, interviewed 27/06/2014).

This also highlights Johansons views that the privileged have a responsibility to those less fortunate, and that they can change their lifestyles to affect change through this. Johanson (interviewed 27/06/2014) stated:

"The assumption is no one has to change their lifestyle. The basic
assumption of all this stuff is that it shouldn't affect the way I live
my life, cause that's set. You can't tell me to change the way I live my
life. Whereas actually trying to say we want to create a space where
people from different neighbourhoods can come and actually see a
way of changing a bit, and adapting." They also try to raise awareness about other cultures involved in the coffee process, such as doing an Ethiopian coffee ceremony by a local Ethiopian woman.

\subsubsection{Marketing approach}

As shown by the name, Roskill has a significant emphasis on their local community but they also promote their use fair trade goods. Johanson $(27 / 06 / 2014)$ stated that they try to attract people into the community through the café who not usually spend time in Mt Roskill. They want people to come and spend time in Mt Roskill, instead of driving through it on their way to somewhere else. 


\subsubsection{Use of profits}

Roskill is not currently making any profits, as they are still servicing loans. But they have been funded to give profits away, so when they do they will become an alternative source of funding for other initiatives, and hope to encourage other social enterprises in the area (Johanson, interviewed 27/06/2014).

\subsection{Summary}

This chapter has described each café as a case study, showing their history, location, model for coffee, organisational make-up, marketing and use of profits. Through this it has shown the different values and models of each of the coffee companies that were interviewed in this research. In each company, there has been a choice of what they deem important by prioritising some issues or locations over others. Some cafés, such as Peoples, have a strong focus on representing their international work with coffee famers, whereas others, such as Crave Café or Roskill Coffee Project, have more a local focus here in New Zealand. As we shall see in the next chapter these preferences are dictated by the people who run these coffee companies, as well as the customers they are trying to appeal to. This is the final step, to show how individuals can outwork their responsibility to distant others through social enterprises in the coffee industry and the wider market. 


\section{Chapter Seven}

\section{Ethical Responsibility of Consumers and Business Owners}

\subsection{Introduction}

"Many of the problems in the world remain unresolved because we continue to interpret capitalism too narrowly. In this narrow interpretation we create a one-dimensional human being to play the role of entrepreneur. We insulate him from other dimensions of life such as religious, emotional, and political dimensions. $\mathrm{He}$ is dedicated to one mission in his business life-to maximise profit" (Yunus, 2006, p. 39).

"If we can acknowledge the distant others that we encounter indirectly through our transactions, we might start to feel that we are encountering them more face-to-face. Perhaps before we make our next purchase we might take a moment to pause and consider the people and planet connections involved in the transaction. Perhaps if we can start to "see" distant others more clearly, it will change not just what but how much we consume" (Gibson-Graham, Cameron, \& Healy, 2013, p.104).

These two quotes show a reframing of how to operate in the economy that is happening, and which needs to continue and become more widespread. The market is being used as a place where individuals have the ability to outwork their ethics through a changed lifestyle and approach to business and work. This is true for both consumers and business owners. The final and critical point is to show how ethical responsibility to distant others can be outworked through social enterprises and the market in general. This chapter will look at consumers, and the crucial role they have in the operation of social enterprises, and in the coffee industry more generally. It will discuss their complicity in economic issues, but also the opportunities they have to make change. Next it will discuss consumer motivations, and how business owners and their companies try to treat and appeal to these motivations. The business owners 
had much to say about the difficulties of appealing to consumers, and the balance that must be struck between the product that is sold and the ethic that is behind it. In the final section, the role of business owners will be discussed, and how literature on social entrepreneurship frames this work. Business owners act as gatekeepers, and decide the values and make up of coffee social enterprises. They can also choose to include and empower those that have been marginalised in economic systems.

\section{$\underline{7.2 \text { Consumers }}$}

\subsubsection{Importance of the consumer}

Consumers play an important role in the discussion of ethics, and in turn how development can be outworked in the market. It is their decision making that in part decides where money goes, and whom it benefits. Gibson-Graham et al. (2013) agrees: "by seeing the economy not as a machine but as the day-today processes that we all engage in as we go about securing what we need to materially function, it's clear that the economy is created by the actions we take" (p.7). Consumers also have their part to play in the economic issues stated in previous chapters. Through their purchasing, they become complicit with inequality and unethical practice in the economy. It is important to note here that an individual is not just a consumer; so making change through consumption is not the only way we can act. To reduce one to a consumer is to reduce their agency in other areas of society as well (such as political). Due to these consumption patterns, there is also a lack of consideration of coffee as a commodity. This is changing in some areas, such as the boutique coffee scene in Wellington. But for the most part, as MaCauley (interviewed 11/06/2014) put it “You don't think about, you don't consider it, that it could be a valuable commodity".

Purchasing coffee in the manner we do in the West is a luxury and is part of a middle-class social lifestyle that can be afforded by some. Through its aesthetic tastes and consumption patterns, the middle class has been fundamental to the emergence of a café culture in many cities throughout history (Weaver, 2010). This group is the main actor in ethical consumption, as 
they have disposable income, high level of education and political awareness required to participate in it (Visser, Marten, Pohl, \& Tolhurst, 2007). Ethical consumption is defined as when retail customers opt for goods that are perceived to create more preferable social, economic or environmental impacts and outcomes than competing equivalents (Visser et al., 2007). It covers how things should be consumed, but also whether they should be consumed at all (Visser, Matten, Pohl, \& Tolhurst, 2007). This term ethical consumption is slightly problematic as it implies that some forms of consumption can be deemed ethical, and others unethical. This was definitely my perception when this research first commenced, but it is seems more difficult to make this judgement now.

\title{
$\underline{7.2 .2 \text { Motivations of consumers }}$
}

It has become clear through the interviews that there are varying ethics and values that people outwork when consuming, where they place an emphasis on one issue over another. This makes it difficult say that one consumptive choice is more ethical than another.

\begin{abstract}
"Because shoppers stand at a distance from production and distribution it would be easy to dismiss them as dupes of cleverly marketed commodities, but this would ignore the sentiments people themselves believe they express when buying fair trade. On the other hand, it cannot be right to automatically champion the opposing and romantic view and depict ethically motivated consumers as heroically resisting and subverting the dominant economic order" (Luetchford, 2008, p. 152).
\end{abstract}

As Luetchford shows, there are various motivations going on in a consumer, which muddy the water when it comes to ethical consumption. There is always a mix of motivations, both self-serving and altruistic, that consumers have when they purchase 'ethical' goods. New sections of the middle class want to differentiate themselves by consuming exotically traditional products (such as coffee), portraying themselves as they wish to be seen and in doing so making a statement about their identity (Weaver, 2010). In this way, "consumption becomes status differentiation and identity formation" (Weaver, 2010, p.50). 
This reveals the 'cool' aspect of coffee consumption, which has definitely occurred in New Zealand's main cities (Auckland, Wellington and Christchurch).

Nevertheless, it is still important for individuals to become aware of the real impact of their consumptive actions. This mix of motivations should not be a reason to dismiss an individual's ethical choice or their possibilities to make changes in the market. The interviews showed that business owners recognise this mix of motivations and values shown earlier that consumers have when it comes to purchasing coffee. So they try to appeal to all of these motivations (such as environmental or social considerations, and quality of product) for purchasing coffee, with perhaps a greater emphasis on some than others. The companies try to connect mainstream consumer wants and needs with ethical issues.

\subsubsection{Raising awareness}

Although there are parts of the middle-class that know of inequalities in the supply-chain, fair trade and other economic issues, there are still many people who do not. Gibson-Graham et al. (2013) state "Ignorance is bargainbasement bliss" (p.86). The lack of understanding that consumers have about the supply-chain, and its goings-on, is the critical issue that is being addressed in this research, and what these companies are doing. Lamason (interviewed 18/06/2014) argued that there is a lie in our consumer culture that our consumption can continue on uninhibited, and that it doesn't affect anyone negatively. People turn a blind eye to the inequalities, and the effect that Western consumerism has on the rest of the world. There is a separation in peoples' minds between what they buy, and the poverty in producing countries. On top of this, the West believes that it can have its wealth, with others becoming just as wealthy. Sachs (2010) states, "the resources required would be too vast, too expensive and too damaging for local ecosystems and the biosphere" (p.x). But these facts have not yet affected how people live. Their consumption continues as if it is entirely unrelated to the inequality in the world. As Lamason (interviewed 18/06/2014) stated, this "works really well for consumers in the West, but terribly for producers of low price products". 
Furthermore, this is an issue of lifestyle for us, but an issue of livelihood for coffee farmers and their communities (Macauley, interviewed 11/06/2014). So a peripheral issue for people in developed countries, where change is possible, is an issue more difficult to change for those in developing countries.

The first step in changing consumer practice is raising awareness. The goal, as Turner (interviewed 25/06/2014) puts it, is to become conscious; conscious of how the market really works, and conscious of ones personal impact in the economy. There needs to be a change in lifestyles, where people assess more critically their decisions and the implications of them on others. Coffee social enterprises provide one avenue for consumers to change what they consume. This creates a new place for choice that was not there before. Coffee companies provide opportunities to purchase ethically traded coffee that would not be there otherwise. Does it alter how much they consume? Perhaps in the processes of these cafés there is less wastage, and it is true that many of them strive to be environmentally friendly. The co-operatives are also encouraged to make their practices environmentally friendly through Biogro and fair trade certification. But other than this, this research is unable to conclude how much change has occurred for consumers due to these coffee social enterprises.

\subsubsection{Opportunity for change}

Individuals in Western countries require a mind shift on how they view the economy. This reinforces the agency of individuals now found in the economy, that we are complicit in economic problems, but we also have the potential to change them. Through the globalisation of the market, more multinational interactions are occurring, with companies trading in ways that are separate to government (Nicholls, 2006). It could be argued as well that once an individual invests their money in to a company, this company represents them wherever they work. Individuals are able to outwork ethics through these companies that are separate from government foreign policy, but are compatible with their ethics, further reinforcing their agency. And with coffee in mind, purchasing a luxury item can add value back (Macauley, interviewed 
11/06/2014). It also shows an appreciative stance to the economy, which is often seen negatively. People can build the economies we live in, and take economic matters into their own hands to create a socially and environmentally just world (Gibson-Graham, Cameron, \& Healy, 2013). Many of these coffee companies want to create an environment where people can see a way of changing (Johanson, interviewed 27/06/2014). Changes in perception are important, particularly between rich and poor in both the local and global contexts these coffee companies work in. Cottle (interviewed 26/06/2014) agreed that Crave Café is more about social advancement than social justice, as they want to work towards a better make-up of society.

Linking to discussions of social enterprise, in that business and charity can be connected, individuals require the same approach with their lifestyles. This also connects to the detachment that consumers have from the supply chain, and where their goods come from. Turner (interviewed 25/06/2014) argued that most people do not think of making their entire lifestyle equitable. Acts of charity are often donations given to a charity, but do not entail an alteration to their lives. Johanson (interviewed 27/06) agreed that many think that their lifetsyle is set, and ethical considerations should not affect it. This reinforces the need of Matthews' (2008) charge for the wealthy to reflect on their lifestyle.

\subsection{Business owners}

Business owners play an important role in coffee companies working as social enterprises, because they define the values of the organisation and its organisational structure. This also dictates whether these companies can be defined as 'doing development' in a way that fits post-development. They are the individuals who decide how their companies will be made up, and what they will prioritise. These business owners than can be described as social entrepreneurs, a term which will be discussed further now and in the concluding chapter. 


\title{
7.3.1 Social entrepreneurship
}

In regards to solving the problems facing society currently, Skoll (2006) makes the following statement:

\begin{abstract}
"Efforts by our governments and institutions have proven insufficient to reverse these destructive trends. Our best hope for the future of humanity lies in the power and effectiveness of socially motivated, highly empowered, individuals to fight for changes in the way we live, think, and behave" (p.v).
\end{abstract}

This is a slightly optimistic view on the power of social entrepreneurship, but it does highlight well the potential good that can come from diversified means of achieving social change. Social entrepreneurship, in the context of social enterprise as discussed previously, is one such alternative. As a phenomenon, it is driven by "a new breed of pragmatic, innovative, and visionary social activists and their networks" and "borrows from an eclectic mix of business, charity, and social movement models to reconfigure solutions to community problems and deliver sustainable new social value" (Nicholls, 2006, p.2). Social entrepreneurs are bringing about systemic change by influencing social behaviour for the good on a global scale (Nicholls, 2006). Nicholls (2006) uses the Fair trade movement as an example, as it has helped "catalyse a revolution" in how consumers view their relationship with producers and has underpinned policy-level reassessments (p.3).

In the chapter on development in the market the idea of Adam Smith's second invisible hand, which promotes his work on moral sentiments, was outlined. Social entrepreneurs can act out themselves, and create avenues for moral sentiments, motivations of care, civic energy, and social commitment to be enacted in the economy (Mulgan, 2006). They "can use market mechanisms to significant effect and make the market an exciting place for fighting social battles in ever more innovative and effective ways" (Yunus, 2006, p. 44). In doing so they attempt to bridge the gap between privileged populations and the poor, and create value in multiple dimensions (Elkington \& Hartigan, 2008). This then provides a possible link of motivations and desired outcomes as development. Key to many social entrepreneurs is that they are working 
towards an ideal, so are more likely to be invested long-term, and unlikely to sell their venture to the highest bidder (Elkington \& Hartigan, 2008).

Elkington and Hartigan (2008) note that because social entrepreneurs focus firstly on social value creation, they are more willing to share their innovations and insights for others to replicate. This is definitely true for the interviewees. For instance Palmer (interviewed 03/06/2014) noted that when Addington Co-op began, it had assistance from Peoples coffee on roasting and general café set up. This in part seems to be a general trait of the coffee industry in New Zealand, but is also due to those shared social values.

\subsection{Summary}

This chapter has taken the final step in this thesis of looking at consumers and business owners, and the role they have to play in the discussion of coffee social enterprises. Consumers play an important role because they are complicit in the economic inequalities discussed in previous chapters, but also because they have the opportunity to make changes to these inequalities. Their motivations are often mixed when engaging in coffee social enterprises, but this is to be expected. There is still more awareness to be raised in the general community about the plight of coffee farmers and local communities here in New Zealand. This chapter has also discussed business owners, and how literature on social entrepreneurship frames the work that they do. As social entrepreneurs, business owners play a key role in setting and continuing the values of a social enterprise. They act as gatekeepers who can choose to include and empower those that have been marginalised in economic systems. 


\section{Chapter Eight}

\section{Case Study Discussion}

\subsection{Introduction}

This chapter will look at the case studies by comparing and contrasting the different each coffee companies. Following the sections used in the case study chapter, it will look at the history, location, supply model for their coffee, organisational structure, marketing approach and use of profits.

\subsection{Case study comparison}

These companies, in most respects, are defined by their values which are unique in the context of the business world. The values of social change, or 'social advancement' as Cottle (interviewed 26/06/2014) put it, are what make these companies unique. In trying to achieve these social goods, each company has consciously constrained their work in ways that other companies would not (by only using fairtrade coffee, for example). It became clear that there is always a focus on a few aspects of achieving this social good. No one business interviewed has tried to cover or make ethical decisions on every situation or part of the market that the other companies tried to address. They do not try and rectify every social situation or market action that the business is a part of.

In terms of revealing the plight of coffee farmers, or getting people to engage with their local community, it became clear in the interviews that you should not 'bang the ethical drum' too hard. Lamason (interviewed 18/06/2014) states that you cannot force people to believe what you believe. This is true for working with customers in cafés as well as sourcing coffee for other cafés. As stated previously, getting a coffee is usually seen as a carefree experience, so people do not want to be confronted with the problems of this world. But, Lamason (interviewed 18/06/2014) also noted that it is also important to work with people who disagree with you, as they are the people these companies are trying to influence. Because of this there needs to be a balance in how much 
information is provided, and how strongly the issues were represented. It seems in many of the companies that the representation of the issues they are addressing is subtle. There was an emphasis on relationship as a better means for transferring values, as oppose to marketing. Lamason (interviewed 18/06/2014) did acknowledge the need for advocates with varying personalities to reach different types of consumers. These companies aim to give people choice in their consumption, instead of forcing something upon them.

\subsubsection{Histories}

The histories of the companies show there was no one way that these companies started. Their histories are as varied as their values. Mike Murphy bought Kokako as an established café from the owners who started it; Peoples was started by Matt Lamason; Crave and Roskill were started by groups of people with shared values for their communities. These varied histories show how the coffee companies are context and people-driven entities. They are responses to unique issues encountered in varied contexts, both locally and globally. Most of the cafés are relatively recent, meaning they have opened in the last 10 years to 15 years. This could link their opening with the ethical turn that was discussed in previous chapters. Indeed, when Kokako was started it was the first organic coffee company in New Zealand.

\subsubsection{Location}

In terms of choice of location, for most of the cafés it was often a deliberate choice based on their values. Crave, Addington Co-op and Roskill Coffee have had long-term commitments to the communities where they started their cafés in, and so were based in those communities. In doing so, they hope that there will be positive change in the communities through their presence. This meant they are often in areas that are not ideal for a café to thrive. Roskill Coffee Project has recently closed down, and the poor location was reported to be one of the reasons (Cawley, 2014). For Kokako, they see themselves as a hub for 
Grey Lynn, but do not seem to have as many aspirations to change the community there.

\subsubsection{Supply model for their coffee}

The companies various focus of values makes them more or less connected to the locale of coffee production and supply. Peoples' focus is on caring for the farmers supplying their coffee, so they are more involved in the farmers in their country of origin. They also roast their own coffee. Crave and Roskill are more focussed on their local community so buy coffee from coffee companies, instead of roasting themselves. Addington does roast its own coffee but leaves interactions with farmers to Trade Aid from whom they purchase the coffee. This could be seen as these companies having more of a balance between community focus here in New Zealand and representing farmers. Kokako has an emphasis on environmental and quality concerns so are quite involved with farmers, but for slightly different reasons to Peoples.

\subsubsection{Organisational structure}

The participants chose the following descriptions from the social enterprise continuum, which describes their organisational structure:

- Addington Co-op: Social business

- Crave Café: Social enterprise

- Kokako Café: Between social business and business with ethics

- Peoples Coffee: Social business

- Roskill Coffee Project: Social business

Other than Crave, all of the companies viewed themselves on the business end of the social enterprise continuum. It did seem that all of them identified more with being businesses than charities. I would agree with all the self-evaluations, except for Roskill Coffee Project, that I would have placed perhaps as a social enterprise, or even a charity with enterprise. They were more willing to use charity or not-for-profit avenues, such as fundraising, to get started. Others such as Addington were vocal about not being seen as a charity, but as a stand-alone business. 
Not all the participants saw themselves as outworking social justice. Cottle (interviewed 26/06/2014) for instance, stated that Crave is not actively addressing systemic injustice, but were rather looking to make the community in Kingsland a better place. He described this a being for social advancement, rather than social justice. This still fits with the values of development. But what is true is that all the participants had clear and strong convictions that were motivating them to do what they did. They are not just part of money making ventures, there to 'make a buck', but are working towards a goal of effecting positive change through their companies. Many of the participants had Christian worldviews, had been to developing countries, had a history in social work, and/or had done study related to development or human geography.

\subsubsection{Marketing Approach}

The marketing of the cafés was also influenced by their respective values. It varies from environmental concerns (the Kokako is a bird that Kokako Café supports the protection of), to care for farmers (such as Peoples, who have named coffee after the farmers they work with), to a community focus. This shows that they are representing their ethics, whilst trying to appeal to the consumer's ethics as well. They are not just trying to build a strong label that draws customers because of its reputation. How the companies market themselves is also expressed through the set-up and design of their cafés. Peoples represents the farmers they work with through photography in the café; Crave's people focus is outworked by being deliberate about the design of the café to encourage interaction and socialising. Again these marketing tools are used to get buy-in from customers. Roskill Coffee Project was very overt, and had WFTO and FLO paraphernalia everywhere. Kokako on the other hand were more understated with their representation of being FLO certified. Its representation was mediated perhaps by their overall aesthetic of being high quality.

\subsubsection{Use of profits}

The use of profits again reflects the values of each company, but also how these social enterprises depart from traditional business models. For instance, 
Addington Co-op uses 30\% of their profit to reinvest in the company, while the rest is re-distributed to local projects or to the coffee farmers. To use well over half of their profits to achieve social aims outside of the company is very unusual for a business, and goes against the assumption that businesses are always profit-driven.

\subsection{Summary}

This chapter has provided a discussion of the various case studies that have been researched. The final chapter will make wider conclusions through answering the research questions posed at the beginning of this thesis. 


\section{Chapter Nine}

\section{Conclusion}

\subsection{Introduction}

Including coffee companies in the development discourse may seem unusual, but through utilising post-development as a lens and social enterprise as a model, at a theoretical level they fit in terms of trying to achieve development outcomes. And by looking at how these companies practically work, with the values they hold and the people they work with, it becomes clear that they can be included in development discourse. Furthermore, these companies interact with people that contribute and are complicit in economic and social inequalities-namely people in the West-and also with those who suffer from inequality in developing countries-namely coffee farmers and their communities. It also is clear that the motivations of the social entrepreneurs are such that they can be placed in the development discourse. These final sections will answer the initial research questions posed, so as to highlight the conclusions of this thesis.

\subsection{What motivates the social entrepreneurs behind the rise of fair trade} coffee retailing in New Zealand, and to what extent are they driven by responsibility to distant others?

Social entrepreneurship is an apt description for the work of coffee company owners. Lamason (interviewed 18/06/2014) showed this when he stated "I tried to cross all these worlds of mainstream consumer wants and needs, biblical justice ideals, and my own enjoyment of coffee and the process of roasting and making coffee". It is interesting here to note that many of the participants were Christian. This is definitely in part due to my positionality as a Christian, which meant that the connections made were through Christian avenues. But it would be interesting to see (in further research perhaps) if there 
is a correlation between social entrepreneurship, social enterprise, and Christian values.

The role of social entrepreneurs in this discussion is important because they are outworking their ethical responsibility through these businesses, which defines how the business operates. For some companies I interviewed, being driven by responsibility to distant others is stronger for some than others. They all though are working from strong ethical values, be it for the environment, or for their local community. In this way they could all be described as working for something other than themselves. They are not just there to earn money, but have causes they are working towards. As business people they are taking it upon themselves to try to change the status quo by addressing a social, economic or environmental issue. They do not see it being rectified by itself.

These social entrepreneurs provide avenues for consumers to be educated, and then outwork ethical responsibility as the business owners do. The consumer however may not necessarily need to share the ethical values of the business or its owner (or the employees for that matter), as long the product is good enough in and of itself. Cottle (interviewed 27/06/2014) agreed that some customers begin to engage more with the values of the company, others do not, and that is ok. However this does not effect long-term change in the consumer culture here in New Zealand.

These social entrepreneurs can be seen as a type of 'gatekeeper', who by living an ethical lifestyle that connects work and ethical values can set an example to others. The business owners have the values (sense of justice, worthy cause), and are working with communities either here or abroad, which give consumers the opportunity to support others. Being an owner or manager of a successful business gives the opportunity to include or exclude other people in their business. They then have the choice to include disempowered peoples in different aspects of their work. This can be at a cost of, for instance, not employing the most qualified person or employing someone that could be deemed risky (such as Crave employing ex-prisoners); or perhaps committing to work long term with coffee farmers (such as Peoples) even if they have crop failures or if other problems arise where another coffee company would get 
their beans elsewhere. This position has great potential to effect social change, and could be adopted and acted upon by companies that not done so already.

\subsection{To what extent does the rise of the fair trade coffee retail sector in New}

\section{Zealand represent an example of post-development theory in action?}

Applying post-development and social enterprise theory to the real life context of coffee companies and consumers who patronise these cafés has been one of the key aspects of this thesis. In particular, Sally Matthews three responses to poverty for the wealthy have been applied to coffee companies and their supply chains. Post-development has taken a critical view of traditional development, and has sought to find alternative ways of doing development. In the market, companies that are social enterprises can be an avenue for this. They hold bottom lines that aim to make a profit, but also to achieve social aims. Postdevelopment also encourages and allows for situation specific solutions to problems, as oppose to a one-size-fits-all mentality. This is a useful framework for coffee social enterprises (and fair trade for that matter) as they are a solution to a specific context. This research does not see social enterprise as a panacea for all issues, as it would only work in certain circumstances, but one that addresses issues of consumption and fair trade in the coffee industry.

Part of Matthews' response to poverty is having a reflective view on the lifestyle of individuals in industrialised nations, such as New Zealand, and the impact they have on distant individuals and the communities they are a part of. The consumerist pattern of developed countries has contributed to poverty in the developing world by affecting the distribution of wealth and resources. This shows that solutions to development issues are not just about doing development in the developing world, though this is obviously important. A significant alteration to the lifestyles of individuals in industrialised nations should be part of development's work to address poverty. This re-framing of post-development empowers the individual to achieve development outcomes in their everyday lives, on top of supporting aid or not-for-profit organisations. Through utilising their own agency and decision making, individuals can make real changes in the economy that affect those in less privileged positions, both 
here and abroad. One small way of doing this is through individuals choosing to patronise coffee companies that use a social enterprise model.

\subsection{Using a case study approach, how do the motives for establishing social} enterprise in the coffee retail sector in NZ vary between different

\section{companies?}

As shown in the discussion chapter, these companies, in most respects, are defined by their values. There is some sort of social, economic or environmental problem they are trying to counteract. They do not see it being rectified by itself. But no one business has tried to cover, or make ethical, every situation or part of the market that the other companies are trying to address. They do not try and rectify every social situation or market action that the business is a part of. There was no one way that these companies started; their histories are as varied as their values. These varied histories show how they are context and people-driven entities. They are people's responses to unique issues in varied contexts. Some of the cafés were more willing to use charity or not-for-profit avenues, such as Roskill, who had crowd-funding to get them started. Others such as Addington were vocal about not being seen as a charity, but as a standalone business.

The companies' various focus of values makes them more or less connected to the locale of their coffee supply. Peoples' focus is on caring for the coffee farmers, so they are more involved in the farmers in their country of origin. They also roast their own coffee. Crave and Roskill are more focussed on the community so buy coffee from coffee companies, instead of roasting themselves. Addington does roast its own coffee but leaves interactions with farmers to Trade Aid, whom they purchase the coffee from. This means they have more of a balance of community focus and representing farmers. Kokako has an emphasis on environmental and quality concerns so are quite involved with farmers, but for slightly different reasons to Peoples. The positions of these cafés mean they have the choice to include disempowered peoples in different aspects of their work. This can be at a cost of not employing the most qualified person or employing someone that could be deemed risky (such as Crave 
employing ex-prisoners); or perhaps committing to work long term with coffee farmers even if they have crop failures or if other problems arise that could mean another coffee company would get their beans elsewhere (such as Peoples.

In terms of choice of location, Crave Café, Addington Co-op and Roskill Coffee have had long-term commitments to the communities that they have started their cafés in. They hope that there will be positive change in the communities through their being there. Marketing is also influenced by values. It varies from environmental concerns and a care for farmers (such as Peoples, who have named their coffee after the farmers they work with). How the café is set up shows their ethics as well. Peoples make a point of representing farmers in the café, Kokako their design and quality ethic, Crave their people focus.

\subsection{To what extent are the retailers I investigate to be characterised as}

\section{social enterprises?}

All of the companies fit on the social enterprise continuum to an extent, as they all have a social value or ethic they are working towards. These enterprises give individuals an opportunity to engage with companies that have social or environmental bottom-lines that the individual would not otherwise have. It provides opportunities for consumers to learn more about the global market and their place in it, and so the affects of their consumerist decisions. It also helps to raise awareness for how much value is added throughout the coffee production process, especially with how much work the coffee farmers put into it.

But these businesses definitely are doing this to more or less a degree. In my view Kokako has the greatest focus on providing a high quality product to consumers, which seems to connect with less of a focus on social impact. Other companies, such as Peoples and Roskill have greater social focus, but this comes as detrimental or limiting to the type of coffee they have access to (only using WFTO coffee, and committing to certain farmers) and the locations they work in (Roskill Coffee Project working in Mt Roskill, a less central suburb). It is then more of a question of what type of social enterprise they are. 


\subsection{What are the remaining challenges for the application of a just coffee}

\section{retail sector in New Zealand?}

There are several remaining challenges for these social enterprises, and the just coffee retail sector they are a part of. The temporary closure of Roskill Coffee Project shows that it is a challenging sector to be part of to be successful. For the sector, it is important for them to continue reaching and influencing new customers, through improved marketing approaches and new locations, and there is room for growth. For the coffee companies, holding true to their original values as the company gets bigger could be another challenge. As new people are employed and they move in to new locations, it is important to instill the values that are core to the company throughout this process.

Longevity could also be a challenge for these coffee companies. Some of the coffee companies interviewed have run for over 10 years, but it will be interesting to see how holding social and financial bottom lines will work longterm. This requires that the business side of the social enterprise is successful. Finally, social enterprise coffee companies (and social enterprises in general) may find it difficult to be perceived as high quality because of the social aspects of their business. Whether these perceptions are well founded or not, it will be a challenge to break them.

\subsection{Final Reflections}

At the beginning of this research process, I hoped to find a means of consumption that was entirely ethical. Over time I have come to realise that this is very difficult to do. From the example of the coffee companies, it became clear that they often focussed on one aspect of social or environmental change, in terms of what they wanted to affect. Sacrifices were made, as it was not possible to focus on all challenges or issues that coffee companies contribute to. Some of the companies focused on environmental issues, others focused on the coffee farmers, and others still had an emphasis on their local community. There is then currently no way of purchasing coffee that is entirely ethical, and conversely there is probably not a way of buying coffee that is entirely unethical. But what is different about the companies that I have researched is 
that, although they acknowledge that their way of working is not perfect, they are actively working towards improving how coffee is sold in a way that is better for the environment, better for coffee farmers and their communities, and one which contributes to the social fabric of their local community. In this way they are working towards social change instead of going along with the status quo.

The main conclusion and challenge for development is to bring development 'home', and to find different ways of 'doing development'. Bringing development home requires a reflection on lifestyles in the West. Development also needs to expand and diversify to engage with different contexts. Engaging in development through the market in a different way to traditional development is a means of doing this. This means acting as individuals and businesses in the market with explicit social aims, and doing this across the entirety of the supply chain, from producer to consumer. This bringing home of development requires a broadening of what is included in the development discourse. 


\section{Appendix 1: Participant information sheet and consent form}

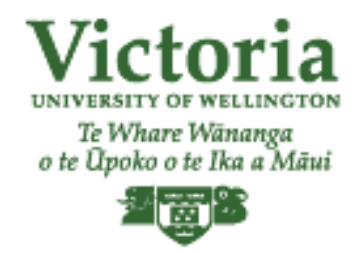

CONSENT TO PARTICIPATE IN RESEARCH

\section{Ethical Responsibility to Distant Others through the Coffee Industry, in light of Post-development}

I have been given and have understood an explanation of this research project. I have had an opportunity to ask questions and have them answered to my satisfaction. I understand that I may withdraw myself (or any information I have provided) from this project before September 12014 without having to give reasons.

Please state (yes or no) on the dotted line to agree to the following statements:

- I consent to information or opinions that I have given being attributed to me in any reports on this research.

- I would like the audio recordings of my interview returned to me at the conclusion of the project.

- I understand that the data I provide will not be used for any other purpose or released to others without my written consent.

- I would like to receive a summary of the results of the research when it is completed.

- I agree to take part in this research.

Signed:

Name of participant:

Date: 


\title{
Victoria \\ UNIVERSITY OF WELLINGTON \\ Te Whare Wānanga \\ o te Upoko o fe Ika a Mäui \\ s.
}

\section{Participant Information Sheet for Interviewee's from Coffee companies}

\author{
Researcher: William Durbin, School of Geography, Victoria University of \\ Wellington
}

I am a Masters student in Development Studies at Victoria University of Wellington. As part of this degree I am undertaking a research project leading to a thesis. The project I am undertaking is examining the ethical responsibility of people in New Zealand to 'distant others', and how this can be outworked in the coffee industry. This research project has received approval from the Victoria University Human Ethics Committee.

I have invited specific individuals to participate in a semi-structured interview. A second may be scheduled if the first interview goes overtime, and both parties agree to continue. Participants will be asked to answer questions about their coffee company, the coffee industry, ethical consumption, as well as their own ethical perspectives on responsibility to distant Others.

It is envisaged that the interview will take about an hour to complete. The time and date of the interview will be negotiated between the participant and researcher. The interview will be recorded. A copy of the recording file can be sent to the participant within a week of the interview, if they wish to review it and make further comments. Should any participants feel the need to withdraw from the interview, they may do so without question as long as reasonable prior warning is given. Any information provided by the participant may be withdrawn by September 12014.

Responses will form the basis of my research project and will be put into a written report. Names will be used in this report unless the participant states otherwise. No other person besides my supervisor Warwick Murray (my supervisor) and myself will see transcriptions or hear the recordings of the interview. The thesis will be submitted for marking to the School of Geography and deposited in the University Library. It is intended that one or more articles will be submitted for publication in scholarly journals. Interview recordings and other records will be destroyed at the conclusion of this research.

If you have any further questions or would like to receive further information about the project, please contact me at 0274668299 or durbinwill@myvuw.ac.nz, or my supervisor Warwick Murray, at the School of Geography at Victoria University warwick.murray@vuw.ac.nz.

William Durbin 


\section{Appendix 2: Interview questions}

\section{Personal questions}

-What prompted you to get involved in the coffee industry?

-Why did you choose to work for this company?

-Do you feel personally a responsibility to coffee producers?

-Do ethics guide your work? If so, how?

\section{Organisation questions}

-Do you consider your company a social enterprise? Where on the spectrum do you think it fits?

-Does your organisation try to tap into a person's sense of ethics or morality? If so, how? Why have you chosen to do it this way?

-Because you work with people from developing countries, do you see yourselves as in any way 'doing development'?

-What benefits have you seen for communities through the work you do with them?

-Do considerations of distant others influence your work? If so, how?

-How do you see your organisation as representing these people?

-Does the coffee rust issue in Latin America affect your company and the relationships with the farmers?

\section{$\underline{\text { Market questions }}$}

-Do you use ethically traded coffee? In what form does this outwork itself?

-Why have you chosen to do it this way?

-Do you see issues with outworking ethics in the market?

-What's your view on coffee co-operatives?

\section{Consumption questions}

-What do you think motivates people in their consumption of coffee?

-What role do you think ethics plays, or can play, in consumption?

-What do you think is the value people place on coffee? 


\section{Reference List}

Addington Co-op. (2014a). Addington Co-op location. Retrieved from http://www.addingtoncoffee.org.nz/past-present-future/

Addington Co-op. (2014b). Addington Co-op logo. Retrieved from

http://www.eventfinder.co.nz/venue/addington-coffee-co-op$\underline{\text { christchurch }}$

Arrow, K. J. (2000). Observations on Social Capital P. Dasgupta \& I. Serageldin (Eds.), Social Capital: A Multifaceted Perspective. Retrieved from http://elibrary.worldbank.org/doi/pdf/10.1596/0-8213-4562-1

Atkinson, P., Coffey, A., Delamont, S., Lofland, J., \& Lofland, L. (Eds.). (2007). Handbook of Ethnography. London: Sage Publications.

Auckland City Council. (2013). Albert Eden Local Board Area. Retrieved from http://www.aucklandcouncil.govt.nz/EN/planspoliciesprojects/plansstr ategies/unitaryplan/Documents/localareafactsheets/upfactsheetalberte denkingsland.pdf

Barnett, C., Cloke, P., Clarke, N., \& Malpass, A. (2005). Consuming Ethics: Articulating the Subjects and Spaces of Ethical Consumption. Antipode, $37(1), 23-45$.

Berthoud, G. (2010). Market. In W. Sachs (Ed.), The Development Dictionary: A Guide to Knowledge as Power (pp. 74-94). London: Zed Books.

Brigg, M. (2002). Post-development, Foucault and the colonisation metaphor. Third World Quarterly, 23(3), 421-436. 
Brockington, D., \& Sullivan, S. (2003). Qualitative Research. In R. Scheyvens \& D. Storey (Eds.), Development Fieldwork (pp. 58-75). London: SAGE Publications Ltd.

Cawley, R. (2014). Community-driven cafe closes. Retrieved from http://www.stuff.co.nz/auckland/local-news/centralleader/63743424/Community-driven-cafe-closes

Chacko, E. (2004). Positionality and Praxis: Fieldwork Experiences in Rural India. Journal of Tropical Geography, 25(1), 51-63.

Chandler, A. E. (2013). Coffee PPPs for development and business. Retrieved from https://www.devex.com/en/news/coffee-ppps-for-developmentand-business/81559

Christchurch City Council. (2013). Community Profile:

Addington/Sydenham/Waltham. Retrieved from http://resources.ccc.govt.nz/files/CityLeisure/statsfacts/statistics/Com munityProfiles/2012/SpreydonHeathcote/ADDINGTONSYDENHAMWAL THAMPoster12.pdf

Cloke, P. (2002). Deliver us from evil? Prospects for living ethically and acting politically in human geography. Progress in Human Geography, 26(5), 587-604.

Corbridge, S. (1998). Development ethics: Distance, difference, plausibility. Philosophy \& Geography, 1(1), 35-53.

Cottle, N. (2014, 26 June). [Personal Communication].

Crave Cafe. (2014a). Crave Cafe location. Retrieved from https://plus.google.com/109574974610034969335/about 
Crave Cafe. (2014b). Crave Cafe logo. Retrieved from

http://www.cravecafe.co.nz/

Cumming, G. (2014). United, The World in a Suburb. Retrieved from http://www.nzherald.co.nz/nz/news/article.cfm?c id=1\&objectid=1131 $\underline{3033}$

Cupples, J., Glynn, K., \& Larios, I. (2007). Hybrid Cultures of Postdevelopment: The Struggle for Popular Hegemony in Rural Nicaragua. Annals of the Association of American Geographers, 97(4), 786-801.

Dasgupta, P., \& Serageldin, I. (2000). Social Capital: A Multifaceted Perspective P. Dasgupta \& I. Serageldin (Eds.). Retrieved from http://elibrary.worldbank.org/doi/pdf/10.1596/0-8213-4562-1

Daviron, B., \& Ponte, S. (2005). The Coffee Paradox: Global Markets, Commodity Trade and the Elusive Promise of Development. London: Zed Books.

Elkington, J., \& Hartigan, P. (2008). The Power of Unreasonable People. Boston: Harvard Business Press.

England, K. V. (1994). Getting Personal: Reflexivity, Positionality, and Feminist Research. Journal of Professional Geographer, 46(1), 80-89.

Esteva, G. (2010). Development. In W. Sachs (Ed.), The Development Dictionary: A Guide to Knowledge as Power (pp. 1-23). London: Zed Books.

Fairtrade AUSNZ. (2010). Fairtrade Sales and Figures and Market Developments. 1,2. Retrieved from http://fairtrade.org.nz/sites/default/files/Fairtrade $\% 20$ Sales $\% 202010$ \%20ANZ.pdf 
Fairtrade AUSNZ. (2011). Awareness of the Fairtrade label continues to rise in New Zealand. Retrieved from http://fairtrade.org.nz/news/awarenessfairtrade-label-continues-rise-new-zealand

Fairtrade AUSNZ. (2012). Global Fairtrade Sales Rise by 12\% on Year - NZ Increase $24 \%$. Retrieved from http://fairtrade.org.nz/news/globalfairtrade-sales-rise-12-year-nz-increase-24

Frances, N. (2008). The End of Charity: Time for Social Enterprise. Crows Nest: Allen and Unwin.

Fridell, G. (2007). Fair Trade Coffee: The Prospects and Pitfalls of Market-Driven Social Justice. Toronto: University of Toronto Press.

Gansky, L. (2014). 5 Signs That The Collaborative Economy Is Going Through Puberty. Retrieved from http://www.fastcoexist.com/3030564/5-signsthat-the-collaborative-economy-is-going-throughpuberty?partner=newsletter

Gather and Hunt. (2014). Roskill Coffee Project location. Retrieved from http://gatherandhunt.co.nz/Profiles/roskill-coffee-project

George, S. (1997). How the Poor Develop the Rich. In M. Rahnema \& V. Bawtree (Eds.), The Post-Development Reader. London: Zed Books.

Gibson-Graham, J. K. (2005). Surplus Possibilities: Postdevelopment and Community Economies. Singapore Journal of Tropical Geography, 26(1), $4-26$.

Gibson-Graham, J. K., Cameron, J., \& Healy, S. (2013). Take Back the Economy. Minneapolis: University of Minnesota Press.

Giovannini, M. (2013). Social Enterprises for buen vivir in Chiapas: An Alternative to Development. Retrieved from 
http://www.unrisd.org/80256B3C005BE6B5/search/D23EF0647F3BC D28C1257B980034954C?OpenDocument

Goodman, M. K. (2004). Reading fair trade: political ecological imaginary and the moral economy of fair trade foods. Political Geography, 23(7), 891915.

Jaffee, D. (2007). Brewing Justice: Fair Trade Coffee, Sustainability, and Survival. Berkeley: University of California Press.

Johanson, R. (2014, 27 June). [Personal Communication].

Jolliffe, L. (Ed.). (2010). Coffee Culture, Destinations and Tourism. Bristol: Channel View Publications.

JustShare. (2012). Paul Chandler on Fairtrade and Christian Attitudes to the Market. Retrieved from https://www.youtube.com/watch?v=5cAkXMGRxuk

Kerlin, J. A. (2006). Social Enterprise in the United States and Europe: Understanding and Learning from the Differences. Voluntas, 17, 247-263. King, T. (2008). Theory After the Hegemon: From Postdevelopment to Neodevelopment. In A. Thorton \& A. McGregor (Eds.), Southern Perspectives on Development: Dialogue or Division? (pp. 141-150). Auckland: Centre for Development Studies, University of Auckland. Kokako Cafe. (2014a). Kokako Cafe location. Retrieved from http://kokako.co.nz/kokako-cafe-gallery/?pid=99 Kokako Cafe. (2014b). Kokako Cafe logo. Retrieved from http://kokako.co.nz/ Lamason, M. (2014, 18 June). [Personal Communication]. 
Lewis, T. (2012). What Does 'Ethical Consumption' Mean? Retrieved from http://ethicalconsumption.org/publications/ethical-consumption$\underline{\text { mean/ }}$

Lincoln, Y. S., \& Guba, E. G. (2000). Paradigmatic controversies, contradictions, and emerging confluences. In N. K. Denzin \& Y. S. Lincoln (Eds.), The handbook of qualitative research (second edition). London: Sage Publishers.

Ludema, J. D., Cooperrider, D. L., \& Barrett, F. J. (2001). Appreciative Inquiry: the Power of the Unconditional Positive Question. In P. Reason \& H. Bradbury (Eds.), Handbook of Action Research: Participatory Inquiry and Practice (pp. 189-199). London: Sage Publications Ltd.

Luetchford, P. (2008). Fair Trade and a Global Commodity: Coffee in Costa Rica. London: Pluto Press.

Macauley, R. (2014, 11 June). [Personal Communication].

Manzo, L. C., \& Brightbill, N. (2007). Toward a Participatory Ethics. In S. Kindon, R. Pain \& M. Kesby (Eds.), Participatory Action Research Approaches and Methods: People, Participation and Place (pp. 33-40). London: Routledge. Marcus, J. (2007). Orientalism. In P. Atkinson, A. Coffey, S. Delamont, J. Lofland \& L. Lofland (Eds.), Handbook of Ethnography (pp. 109-117). London: Sage Publications.

Matthews, S. (2007). What, then, should we do? Insights and experiences of a Senegalese NGO. In A. Ziai (Ed.), Exploring Post-development: Theory and practice, problems and perspectives (pp. 131-144). Abingdon: Routledge. 
Matthews, S. (2008). The Role of the Privileged in Responding to Poverty: perspectives emerging from the post-development debate. Third World Quarterly, 29(6), 1035-1049.

McEwan, C., \& Goodman, M. K. (2010). Place Geography and the Ethics of Care: Introductory Remarks on the Geographies of Ethics, Responsibility and Care. Ethics, Place \& Environment, 13(2), 103-112.

McGregor, A. (2009). New Possibilities? Shifts in Post-Development Theory and Practice. Geography Compass, 3(5), 1688-1702.

Mulgan, G. (2006). Cultivating the Other Invisible Hand of Social Entrepreneurship: Comparative Advantage, Public Policy, and Future Research Priorities. In A. Nicholls (Ed.), Social Entrepreneurship: New Models of Sustainable Social Change (pp. 74-95). Oxford: Oxford University Press.

Murphy, M. (2014, 27 June). [Personal Communication].

Murray, W. E., \& Overton, J. (2003). Designing Development Research R.

Scheyvens \& D. Storey (Eds.), Development Fieldwork. Retrieved from http://dx.doi.org/10.4135/9781849208864

Neuman, W. L. (2006). Social Research Methods: Qualitative ad Quantitative Approaches. Boston: Pearson Ltd.

Nicholls, A. (Ed.). (2006). Social Entrepreneurship: New Models of Sustainable Social Change. Oxford: Oxford University Press.

Nocera, J. (2012). The Good, Bad and Ugly of Capitalims. Retrieved 13/11/2014, from http://www.nytimes.com/2012/03/17/opinion/nocera-the-good$\underline{\text { bad-and-ugly-of- }}$

capitalism.html? r=4\&nl=todaysheadlines\&emc=edit th $20120317 \&$ 
OECD. (2000). Social Enterprises. Retrieved from http://www.oecd-

ilibrary.org/urban-rural-and-regional-development/socialenterprises 9789264182332 -en

Palmer, A. (2014, 03 June). [Personal Communication].

Peoples Coffee. (2014a). Peoples Coffee Constable Street location. Retrieved from http://peoplescoffee.co.nz/open-for-business/

Peoples Coffee. (2014b). Peoples Coffee logo. Retrieved from http://peoplescoffee.co.nz/

Pieterse, J. N. (2000). After post-development. Third World Quarterly, 21(2), 175-191.

Reed, J. (Ed.). (2007). Appreciative Inquiry. Appreciative Inquiry. SAGE Publications, Inc. Thousand Oaks, CA: SAGE Publications, Inc.

Roskill Coffee Project. (2014). Roskill Coffee Project logo. Retrieved from http://www.roskillcoffeeproject.co.nz/

Sachs, W. (Ed.). (2010). The Development Dictionary: A Guide to Knowledge as Power. London: Zed Books.

Schmelzer, M. (2010). Marketing Morals, Moralizing Markets: Assessing the Effectiveness of Fair Trade as a Form of Boycott. Management and Organizational History, 5(2), 221-250.

Silk, J. (2004). Caring at a distance: gift theory, aid chains and social movements. Social \& Cultural Geography, 5(2), 229-251.

Simon, D. (2006). Seperated by common ground? Bringing (post)development and (post)colonialism together. The Geographical Journal, 172(1), 10-21. Skoll, J. (2006). Preface. In A. Nicholls (Ed.), Social Entrepreneurship: New Models of Sustainable Social Change (pp. v, vi). Oxford: Oxford University Press. 
Smith, D. (2000). Moral Geographies: Ethics in a World of Difference. Edinburgh: Edinburgh University Press.

Stewart, H. (2012). Co-operative model could be the answer to economic woes, from http://www.theguardian.com/business/2012/nov/04/cooperative-model-enjoys-a-renaissance

Storey, A. (2000). Post-Development Theory: Romanticism and Pontius Pilate politics. Development 43(4), 40-46.

Trade Aid. (2009). Trade Aid Times: Trade Aid Annual Report 2008-2009 (pp. 1-16). Christchurch: Trade Aid.

Turner, B. (2014, 25 June). [Personal Communication].

Visser, W., \& Matten, D. (2007). The A to Z of CSR - Introduction. In W. Visser, D. Matten, M. Pohl \& N. Tolhurst (Eds.), The A to Z of Corporate Social Responsibility (pp. ix-xiv). West Sussex: John Wiley \& Sons.

Visser, W., Matten, D., Pohl, M., \& Tolhurst, N. (Eds.). (2007). The A to Z of Corporate Social Responsibility. West Sussex: John Wiley \& Sons.

Watkins, J. M., Mohr, B. J., \& Kelly, R. (2011). Appreciative Inquiry : Change at the Speed of Imagination. Retrieved from http://VUW.eblib.com/patron/FullRecord.aspx?p=675213

Weaver, A. (2010). Cafe Culture and Conversation: Tourism and Urban(e) Experiences in Wellington, New Zealand. In L. Jolliffe (Ed.), Coffee Culture, Destinations and Tourism (pp. 41-52). Bristol: Channel View Publications. Wolf, M. (2012). Is Unlimited Growth a Thing of the Past. Retrieved from http://www.businessspectator.com.au/article/2012/10/3/interestrates/unlimited-growth-thing-past 
Yunus, M. (2006). Social Business Entrepreneurs. In A. Nicholls (Ed.), Social Entrepreneurship: New Models of Sustainable Social Change (pp. 39-44). Oxford: Oxford University Press.

Ziai, A. (Ed.). (2007). Exploring Post-development: Theory and practice, problems and perspectives. Abingdon: Routledge. 